ZOOLOGIA 27 (4): 577-642, August, 2010

doi: $10.1590 /$ S1984-46702010000400010

\title{
Systematic review and cladistic analysis of the Hernandariinae (Opiliones: Gonyleptidae)
}

\author{
Marcio Bernardino DaSilva ${ }^{1} \&$ Ricardo Pinto-da-Rocha ${ }^{2}$
}

\author{
${ }^{1}$ Departamento de Sistemática e Ecologia, Centro de Ciências Exatas e da Natureza, Universidade Federal da Paraíba. \\ Cidade Universitária, 58059-900 João Pessoa, PB, Brazil. E-mail: 1940@uol.com.br \\ 2 Departamento de Zoologia, Instituto de Biociências, Universidade de São Paulo. Rua do Matão, Travessa 14, 101, \\ Caixa Postal 11461, 05422-970 São Paulo, SP, Brazil. E-mail: ricrocha@usp.br
}

\begin{abstract}
The harvestmen subfamily Hernandariinae is reviewed and a new classification is proposed based on cladistic analysis using 67 morphological characters. The subfamily is composed of six genera and 23 species and occurs in south-southeastern Brazil, Paraguay, and northeastern Argentina. Fourteen new combinations are proposed: Hernandaria armatifrons (Roewer, 1917); H. una (Mello-Leitão, 1927); Acrogonyleptes granulatus (H. Soares, 1966); A. pectinifemur (Soares \& Soares, 1947); Acanthogonyleptes alticola (Mello-Leitão, 1922); A. editus (Roewer, 1943); A. fallax (MelloLeitão, 1932); A. fulvigranulatus (Mello-Leitão, 1922); A. marmoratus (Mello-Leitão, 1940); A. pictus (Piza, 1942); $A$. singularis (Mello-Leitão, 1935); A. soaresi (Mello-Leitão, 1944); A. variolosus (Mello-Leitão, 1944). Seven synonymies are proposed: Proweyhia Mello-Leitão, 1927 and Metaxundarava Mello-Leitão, 1927 = Hernandaria Sørensen, 1884; Apembolephaenus calcaratus Soares \& Soares, $1945=$ H. armatifrons (Roewer, 1917); Sphaerobunus Rower, 1917 and Paraproweyhia Soares \& Soares, 1947 = Acrogonyleptes Roewer, 1917; Paraproweyhia curitibae Soares \& Soares, $1947=$ Acrogonyleptes exochus (Mello-Leitão, 1931); and Melloleitaniana curitibae B. Soares, $1943=$ Acrogonyleptes spinifrons Roewer, 1917. Three species are revalidated: Acrogonyleptes granulatus (H. Soares, 1966), A. pectinifemur (Soares \& Soares, 1947), and A. spinifrons Roewer, 1917. Seven new species are described: Hernandaria sundermannorum sp. nov. (São Paulo State, Brazil), Hernandaria anitagaribaldiae sp. nov. (Santa Catarina State, Brazil), Hernandaria zumbii sp. nov. (Santa Catarina State, Brazil), Hernandaria chicomendesi sp. nov. (Santa Catarina State, Brazil), Acrogonyleptes cheguevarai sp. nov. (Rio Grande do Sul State, Brazil), Pseudotrogulus pagu sp. nov. (São Paulo State, Brazil), Pseudotrogulus trotskyi sp. nov. (Paraná State, Brazil).
\end{abstract}

KEY WORDS. Atlantic Rain Forest; endemism, harvestmen.

The Atlantic Rain Forest harbors the highest diversity of harvestmen species in the world, with almost 600 described species, of which $97.5 \%$ are exclusive of this biome (PINTO-DARocha et al. 2005). Despite the importance of the group, knowledge on the Neotropical harvestmen systematics is still poor (PINTO-DA-Rocha 2002). The Neotropical harvestmen systematics developed mainly during the first half of XX century, when Roewer $(1913,1923,1930,1943)$ and Mello-Leitão $(1923,1932)$ described most Atlantic Forest species. Generic descriptions were based on subjective methodology, using single characters to define groups, mainly valuing differences, some of which were intra-specific variations or related to secondary sexual characters, making the so called "Roewerian" classification highly unsatisfactory under modern standards (KuRY 1989, 1990, PINTODA-ROCHa 1997, 2002).

Currently, the Atlantic Rain Forest harvestmen are receiving great attention and several groups were recently revised, most of them resulting in new classifications based on cladistic approaches. The following laniatorean groups within Gonyleptidae were recently revised: Bourguyiinae (YAMAGUTI \& Pinto-da-Rocha 2009), Caelopyginae (Pinto-DA-Rocha 2002), Goniosomatinae (DASILVA \& GNaSPINI 2009), Heteropachylinae (A.C. Mendes, unpublished data), Progonyleptoidellinae and Sodreaninae (PINTO-DA-Rocha \& BRAgagnolo, unpublished data), Gonyleptinae genus Mischonyx Bertkau (E.G. Vasconcelos, unpublished data), Pachylinae genus Eusarcus Perty (Hara \& PINTO-DA-Rocha 2010), Cosmetidae genus Metavononoides Roewer (C.P. Ferreira, unpublished data), and the Sclerosomatidae (Eupnoi) genus Jussara Mello-Leitão (Tourinho \& Kury 2003). Such emphasis in Gonyleptidae is because it is the largest family of the suborder Laniatores, with more than 800 described species, all from the Neotropics (KuRY 2003) and dominant in the Atlantic Forest, with approximately 200 endemic species from this biome. 
Among the subfamilies mostly living in this biome is Hernandariinae, distributed from Rio de Janeiro (Serra dos Órgãos) to the southern borders of the Atlantic Forest in Argentina and Paraguay. The subfamily and its genera have loose definitions and there is no phylogenetic hypothesis for its species. Thus, the aim of this study is to review the subfamily and propose a new classification based on a cladistic analysis, enhancing the knowledge of harvestman systematics and enabling future studies on their diversity and biogeography.

\section{Historical account of Hernandariinae}

The taxonomic history of Hernandariinae is characterized by sudden changes in diagnosis and taxa composition. It was erected as the monotypic family Hernandaroidae Sørensen, 1884, based on Hernandaria scabricula Sørensen, 1884, and was diagnosed by the presence of two transversal sulci on the mesotergum and how the defensive secretion was eliminated from the ozopore, which was concealed by the apophyses. Holmberg (1902) described Apembolephaenus Jorgei (sic), which would have future consequences on Hernandaria.

During the 1910 decade, Roewer began his large contribution to harvestmen systematics, dividing SøRENSEN's (1884) four laniatorean families into 13 subfamilies of Gonyleptidae (RoEwER 1913). In this work, he included in Hernandariinae the monotypic genera Hernandarioides Pickard-Cambridge, 1905, Hernandria Banks, 1909 and Saramacia Roewer, 1913. In addition to the name similarities, RoEwER (1913) maintained the presence of two sulci on the mesotergum as the main diagnostic character for the group. This resulted in a group comprising biogeographically disjunct monotypic genera: Rio da Prata, Argentina (Hernandaria), Central America (Hernandarioides and Hernandria), and Amazon region (Saramacia). Roewer (1931) included Glysterus Roewer, 1931 (Central America) and Stygnoleptes Banks, 1914 (Central America and the Andes), and in 1943 the Central American Glysteroides Roewer, 1943. SøRENSEN (1932) described Ariaeus tuberculatus in Hernandarioidae. The outdated group name was because the article was a posthumous publication edited by Henriksen, based on Sørensen's earlier manuscripts and did not incorporate the systematic changes proposed by Roewer (1913). Although Sørensen (1932) placed A. tuberculatus in Hernandariinae, Henriksen stated in a note that the species should be allocated in Pachylinae. Mello-Leitão (1933a) published the transfer, formalizing Henriksen's note.

Since 1940, the so called "Roewerian classification system" began to be abandoned. Roewer's exact taxonomical formulas, using single characters subjectively chosen to delimit taxa were confusing and led to an overestimated number of genera and species (e.g. Kury 1990, Pinto-Da-Rocha 2002). Goodnight \& Goodnight and Soares \& Soares reversed this tendency and began transferring Hernandariinae genera to other subfamilies, such as Glysterus and Hernandria to Gonyleptinae (Goodnight \& Goodnight 1947, Soares \& Soares 1949, respectively) and Hernandarioides to Pachylinae (SOARES \& SoAres 1954).
Influenced by this new systematic approach, RINGUELET (1959) presented a complete discussion on characters and the definitions of the Gonyleptidae subfamilies in which the subjective use of the number of sulci in the mesotergum was replaced by the use of the number of areas, indicated by the position of the tubercles and the width of coxae IV (RINGUelet $1955 a, b, c, 1959)$. Thus, based on a large number of Argentinean specimens of Hernandaria scabricula, Ringuelet (1955a) transferred the type genus of the subfamily to Pachylinae, synonymizing with Hernandariinae. In the same article, he also synonymized the genus Apembolephaenus Holmberg, 1909 under Hernandaria, increasing its number of species and distribution range to the state of Paraná.

The original identity and composition of Hernandariinae became very incongruent with the advent of this new systematic approach, which came into use during the late XX century. Of the seven genera that originally composed the subfamily (Roewer 1913, 1931, 1943), two are currently allocated in other families, Saramacia in Manaosbiidae and Stygnoleptes in Zalmoxidae, and the remaining five are considered incertae sedis within Gonyleptidae (Kury 2003).

SOARES \& SoARes (1984) revalidated Hernandariinae based on a new diagnosis, including the two characteristics already cited by SøRENSEN (1884): presence of ozopores concealed by apophyses; the emission of defensive secretions towards the ventral part of the body; anterior margin of the prosoma with a pair of central, pointed and geminated apophysis and two or three spines on each side; and the body covered by small, densely distributed granules. In this new concept, Hernandariinae included Hernandaria Sørensen, 1884, with four species, Acrogonyleptes Roewer, 1917, with four species, and the monotypic Ariaeus Sørensen, 1932. Besides Hernandariinae, they (SOARES \& SoARes 1984) also redefined Acrogonyleptes, which became a senior synonym of four genera formerly in Gonyleptinae (Proweyhia Mello-Leitão, 1927; Acrogonyleptoides Mello-Leitão, 1931; Melloleitaniana B. Soares, 1943; and Pseudoacrogonyleptoides H. Soares, 1966), distributed throughout the states of Paraná and Santa Catarina. Ariaeus was placed back again in Hernandariinae based on Sørensen’s (1932) description of "peculiar openings of the odoriferous glands", although they suggested that Ariaeus might constitute a family of its own. However, “(...) since we do not know its type species, we prefer to keep it in Hernandariinae" (Soares \& Soares 1984). In fact, Sørensen was the only one to publish any information on the type specimen.

In light of this new concept with more detailed diagnostic characters, the proposition of taxa closely related to Hernandariinae became possible. Thus, Firmo \& Pinto-DA-Rocha (2002) included Pseudotrogulus Roewer, 1932, originally in Gonyleptinae, with three species: Pseudotrogulus telluris Roewer, 1932; Pseudotrogulus mirim Kury, 1992; and the new species Pseudotrogulus funebris Firmo \& Pinto, 2002. The authors also redefined the subfamily and listed the following possible synapomorphies: median sized tubercles located at the angles 
of the anterior margin of the dorsal scute; ocularium with a pair of anteriorly directed convergent tubercles; and a dorsal scute camouflaged with debris. The inclusion of Pseudotrogulus in Hernandariinae had two very interesting implications. First, since Pseudotrogulus does not present sexual dimorphism on leg IV, it imposes interesting evolutionary transformations within Hernandariinae, as well as a greater morphological divergence. Second, the distribution of the subfamily is extended northwards, including the central part of the Atlantic Rain Forest, from Serra dos Órgãos, in Rio de Janeiro, to Serra do Mar, in São Paulo.

DaSiLVA \& Kury (2007) included two genera without sexual dimorphism on leg IV in the subfamily: Piassagera Roewer, with a single species, Piassagera brieni Roewer, 1932, from the Serra do Mar of São Paulo, and Multumbo, with Multumbo terrenus Roewer, 1932 and a new species, Multumbo dimorphicus DaSilva \& Kury, 2007, from the Serra dos Órgãos of Rio de Janeiro, both transferred from Gonyleptinae.

Finally, Ariaeus tuberculatus Sørensen, 1932 was synonymized with the gonyleptinean Geraecormobius clavifemur by VASCONCELOS (2005).

At present, Hernandariinae is distributed from Rio de Janeiro, along the Atlantic Forest of Southeastern and Southern Brazil, to the flat regions of the Rio da Prata River Basin, in Argentina and Paraguay, comprising 14 species and five valid genera.

\section{MATERIAL AND METHODS}

A total of 545 specimens have been examined. Repositories are: Instituto Butantan, São Paulo, São Paulo State (IBSP); Museu de Zoologia of the Universidade de São Paulo, São Paulo, São Paulo State (MZSP); Museu Nacional of the Universidade Federal do Rio de Janeiro, Rio de Janeiro, Rio de Janeiro State (MNRJ); Museu de História Natural do Capão da Imbuia, Curitiba, Paraná State (MHNCI); Hélia Soares' private collection, currently deposited in MNRJ (HSCP); Museu de Ciências Naturais of the Fundação Zoobotânica do Rio Grande do Sul, Porto Alegre, Rio Grande do Sul State (MCN); Museu de Ciência e Tecnologia of the Pontifícia Universidade Católica do Rio Grande do Sul, Porto Alegre, Rio Grande do Sul State (MCTP); Carlos Nicolau Gofferjé's private collection, Blumenau, Santa Catarina State (CGPC), all in Brazil and the Senckenberg Research Institute and Museum, Frankfurt am Main, Germany (SMF).

Most of the holotypes of described species were examined, except Melloleitaniana pectinifemur Soares \& Soares, 1947 and Pseudotrogulus mirim Kury, 1992, for which only the paratypes were examined (MZSP 941/978 and MNRJ 6530, respectively). The holotypes of Paraproweyhia curitibae Soares \& Soares, 1947 (J. Leprevost's private collection), Hernandaria scabricula Sørensen, 1884 (Zoologisk Museum Universität København, ZMUC) and Apembolephaenus jorgei Holmberg, 1909 (lost, SoAres \& SoARes 1954) were not examined.

Illustrations of morphological structures are displayed by species in plates arranged in alphabetical order, with new spe- cies at the end, beginning with the genus Hernandaria, followed by Acrogonyleptes, Multumbo, Piassagera and Pseudotrogulus (Figs 13-111). These are followed by plates displaying palps (Figs 112117) and penises (Figs 118-130).

Scanning electron micrographs (SEM) were taken using ZEISS DSM 940 electron microscope from the Laboratório de Microscopia Eletrônica in the Instituto de Biociências of the Universidade de São Paulo. Penises were prepared according to methodology described in PINTO-DA-RochA (1997b). In some cases (Figs 135-137, 146-151, 152-155, 156-158, 159-165 and 168173) the material was critical point dried, using a Critical Point Dryer BAL-TEC CPD 030.

Descriptions were based on all the examined material. Thus, variations are followed by the state of the type specimen in parenthesis. Description of male is complete and differences between sexes are listed below. Characters mentioned in genus and subfamily diagnoses are omitted from the species descriptions. In synonymic lists, the following abbreviations were used: (desc) description, (redesc) redescription, (syst) taxonomic change, (cat) catalogue citation, (key) identification key, (cit) any other type of citation.

Terminology for morphological structures follows DASILVA \& GNASPINI (2009). "Granules" (always in plural) indicate smaller elevations concentrated in a region or structure. "Tubercles" indicate elevations that stand out due to the size of the granules. "Spines" indicate elevations which are similar to tubercles but are conical and acuminated. "Apophyses" are irregular shaped structures found at the anterior margins of the dorsal scute, apex of coxae IV, trochanter IV and at the base of male femur IV. Acosta et al. (2007) proposed a standard nomenclature for harvestmen systematics, but we decided to present a system which is better adapted to hernandariine morphology.

Arrangements of structures in the penis are described as shown in figures. For example, "horizontal row" refers to it being perpendicular to main axis of penis.

We have used the taxon+ notation of АмовIм (1982) to name the clades without a taxonomical identity. Thus, "taxon+" indicates "taxon plus its sister-group".

The cladistic analysis comprised 33 terminals, with 23 Hernandariinae species and an outgroup composed of the ten species: 1) Bourguyiinae - Bourguyia trochanteralis (Roewer, 1943) - MZSP 16807, 19334; 2) Pachylinae - Ogloblinia loretoensis Canals, 1933 - MZSP 1772; 3) Caelopyginae-Caelopygus elegans (Perty, 1833) - MZSP 14842, 14843; 4) Gonyleptinae-Gonyleptes fragilis Mello-Leitão, 1923 - MZSP 15834, 17631, 17658; 5) Mischonyx insulanus (H. Soares, 1972) - MZSP 16697, 16830; 6) Mischonyx squalidus Bertkau, 1880 - MZSP 16688, 17878, 21791; 7) Acanthogonyleptes fulvigranulatus (Mello-Leitão, 1922) comb. nov. - MZSP 15741, 17712; 8) Progonyleptoidellinae Gonyleptoides marumbiensis B. Soares, 1945 - MZSP 1030, 18761; 9) Progonyleptoidellus striatus (Roewer, 1913) - MZSP 17044, 17635, 22869; and 10) Sodreaninae - Zortalia leprevosti Soares \& Soares, 1947 - MZSP 16803, 19259. 
The outgroup is comprised of species belonging to four subfamilies closely related to Hernandariinae, according to hypotheses proposed by PINTO-DA-Rocha (2002), KurY (1992) and Kury \& Pinto-DA-Rocha (1997) and one species of Pachylinae, and one Bourguyiinae. Bourguyia trochanteralis was used to root the trees because it is more basal among the species of the outgroup (PINTO-DA-Rocha 2002: fig. 10).

Characters were coded with a tendency towards the proposition of ordered multistate characters, following the discussion on "composite" characters presented by WiLKINSON (1995) and M.B. DaSilva (unpublished data). The primary homology hypothesis, determined by the variation of the structures, can be coded by dividing a pattern into several variables, creating several binary characters, or by maintaining the general patterns observed for a character, using ordination to maintain the original information (see discussion in "Cladistic Analysis" under "Results"). This coding dichotomy was treated as "synthetic x reflective" (Pogue \& Mickevich 1990), "reductive x composite" (WiLKInSON 1995, STRONG \& Lipscomb 1999) and "separate x fused" (Lee \& Bryant 1999). The choice of a "composite" coding in this paper is due to the variation observed within the Hernandariinae species (see more in "Discussion" under "Cladistic Analysis"). Multistate characters were ordered whenever we observed an indication of a transformation series among states. To observe the effects of ordination over the analysis results, an additional analysis was carried out using the same matrix and non-ordered characters.

Autapomorphies which are represented by binary characters were not included in the matrix. These resulting cladogram autapomorphies were caused by homoplasies or nonshared states of multistate characters.

The character matrix was edited using NDE 0.5.0 version (PAge 2001). Parsimony analysis was carried out using computer software Paup 4.0b10 (SwofFord 2002) and Nona 2.0 (GolobofF 1999); Nona 2.0 was used with interface Winclada 0.9.9 (NixON 1999). The use of exact search algorithms was not possible due to the large number of taxa, thus we opted for the heuristic search algorithm, TBR (tree bisection and reconnection). The commands "hold10000; mult*1000; hold/1000" and "mult*max" were used in Nona 2.0, and "hsearch addseq = random nreps = 1000 hold $=100$ " in Paup 4.0b10. The smaller number of trees held in each program is due to the amount of time each software takes to carry out the search.

Bremmer support index (BREMER 1994) was calculated for each node of the proposed phylogenetic hypothesis. It shows how many extra steps are necessary to collapse the node, assessing sub optimal trees. The index was calculated with Paup $4.0 \mathrm{~b} 10$, using the command "constraint" followed by the parenthetical notation of the clade in question.

Analysis using successive (FARris 1969, CARPENTER 1988) and implied (GоLовоғF 1993) weighting approaches were also carried out. These methods were used as an alternative to equal weighted character parsimony to test character reliability (FARRIS 1969, CAR-
PENTER 1994) or how much a character converges with the most parsimonious topology. These hypotheses are based mainly on more congruent characters, i.e. those that adjust better to the topology and are less homoplastic, which receive greater weight. Weighting was also used to choose amongst the most parsimonious trees (CARPENTER 1988, Rodrigo 1992) resulting from the equal weighted analysis with unordered characters. Successive weighting was carried out in Paup $4.0 b 10$ using the commands "reweight index = ri fit = maximum" or "reweight index = ri fit = minimum" followed by the heuristic search described above. This routine was repeated until the length of the trees obtained in a search equaled the length of the trees obtained in a previous search (FARRIS 1969). The reweighting commands indicate the index chosen to weigh the character, in this case the retention index (ri), and which ri's of most parsimonious trees obtained was used, the minimum and maximum for each character. In these cases, analyses were carried out using both values. Implicit weighting was carried out using T.N.T. 1.0 (Goloboff et al. 2003) with concavity indexes (Goloboff 1993) varying from 1-6 (six analyses). This index shows the weight difference between less and most homoplasious characters. Concavity index 1 applies harder penalties to the characters that adjust less to the tree. In the discussion of the results, the characters are indicated between brackets.

\section{RESULTS AND DISCUSSION}

\section{Characters of cladistic analyses}

The characters used in the cladistic analysis are listed in Appendix 1. The length (L), consistence index (ci), retention index (ri) and if each character is ordered are parenthesized. A total of 67 morphological characters, mainly related to body ornamentation, were coded including those on the dorsal scute (28 characters), venter (four), free tergites (nine), pedipalps (four), legs (16, seven of them related to secondary sexual characters of male), and related to penis (six). Twenty-three characters were coded as multistate and 14 of them were coded as ordered. The data matrix is in Appendix 2.

\section{The Hernandariinae clades and their new taxonomy}

We obtained two most parsimonious trees $(\mathrm{L}=277, \mathrm{CI}=$ 0.35 e RI $=0.68$, Fig. 1) in which the monophyly of Hernandariinae is confirmed. The subfamily is divided in two main clades: species with sexual dimorphism on leg IV, with males presenting strong armature especially on coxae and femur IV (Figs 13-15, 48-50, 78-81 and 88-90); and species without sexual dimorphism on leg IV, where both males and females have similar legs (Figs 102 and 105).

The sexually dimorphic clade includes mainly Hernandariinae sensu SOAREs \& SOARES (1984), i.e. including Acrogonyleptes, Hernandaria and Ariaeus - latter synonymized under Geraecormobius clavifemur, Gonyleptinae (VASCONCELos 2005). Nevertheless, the delimitation of genera is here modified, changing their 
diagnosis and species composition (Fig. 1). SoAres \& SoAres (1984) classify the genera according to the number of sulci in the mesotergal areas, four in Acrogonyleptes and two or five in Hernandaria; the armature of the free tergites (armed or unarmed); the fusion of the tubercles in area III (fused or separated); and the presence of large convergent spines on the ocularium in Hernandaria. Nevertheless, the authors did not explain the placement of Proweyhia una in Acrogonyleptes, since males of this species do not have armed tergites and have separate tubercles on area III. In addition, they included Metagonyleptes armatifrons, a monotypic genus described based on a female. Additionally, even though they did not examine the type material, they (erroneously) synonymized $M$. armatifrons under Acrogonyleptes spinifrons.

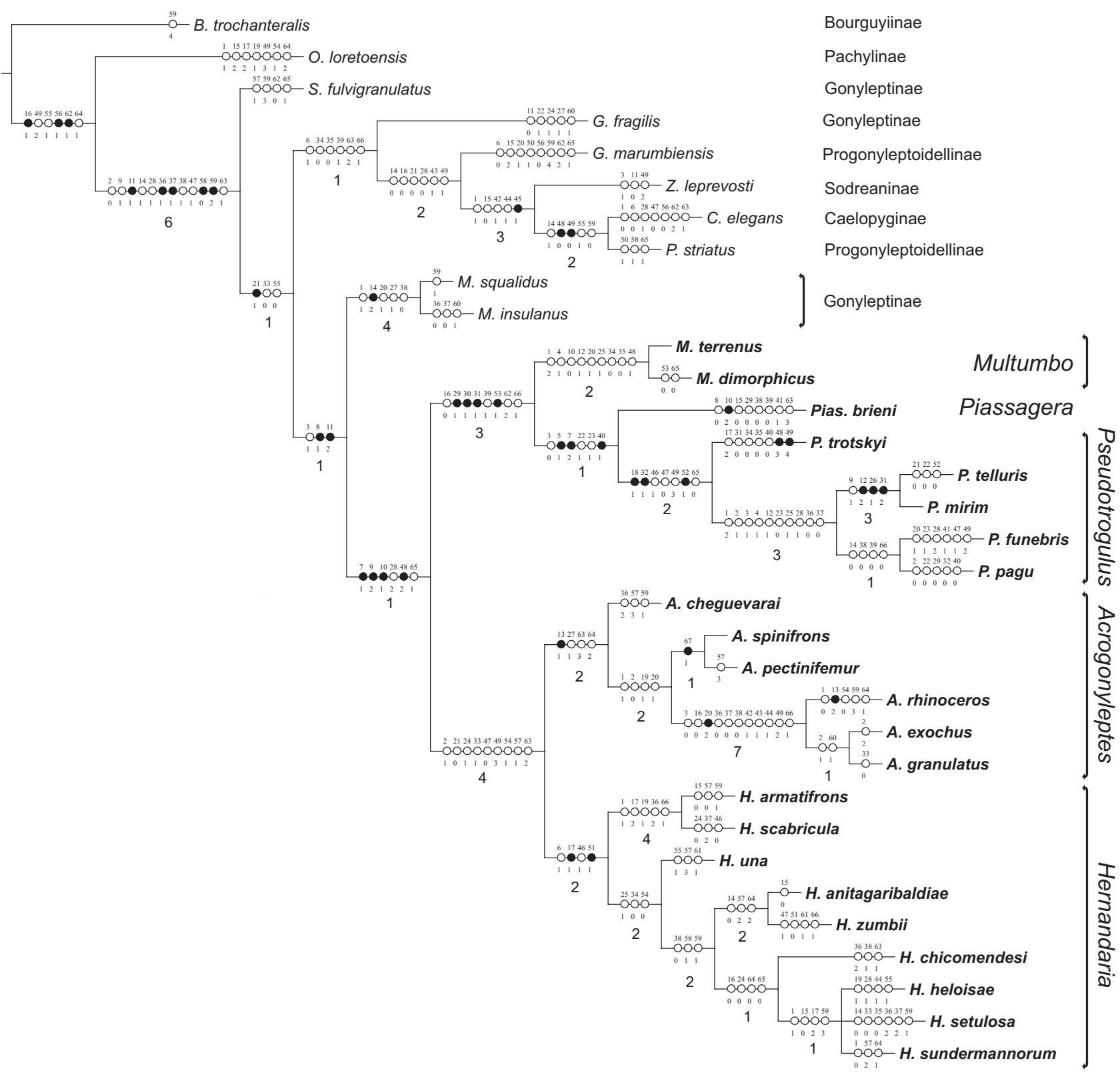

Figure 1. Strict consensus $(\mathrm{L}=278 ; \mathrm{ci}=.34 ; \mathrm{ri}=.68)$ of two most parsimonious trees $(\mathrm{L}=277 ; \mathrm{ci}=.35 ; \mathrm{ri}=.68)$ representing the phylogenetic relationships of the Hernandariinae. $(\bullet)$ Unique transformations, $(O)$ homoplastic transformations. Ambiguous transformations in ACCTRAN optimization. Bremer support index under each node. 
In our hypothesis, Acrogonyleptes unus and A. armatifrons are transferred to Hernandaria - the latter species being synonymized with Hernandaria calcarata. Hernandaria is redefined according to the two non-ambiguous synapomorphies: 1) four flattened mesotergal areas, with very shallow sulci ([6] and [17]), and 2) leg tubercles arranged in similar, regular rows ([51]). Two more synapomorphies could also support the genus: 3 ) the presence of strong ventral tubercles on femur I ([51], using ACCTRAN) and 4) a deeper distal concavity of the ventral plate of the penis ([63] using DELTRAN). Large spines on ocularium (character 1) appear at least twice within the genus, while four new species present small, convergent tubercles, which falsify this synapomorphy proposed by SOARes \& SOARES (1984).

Acrogonyleptes now includes six species: one new species (A. cheguevarai sp. nov.), two species previously assigned by SOARES \& SOARES (1984) (A. spinifrons = A. curitibae, synonymized here, and $A$. exochus), two species previously considered junior synonyms of $A$. spinifrons and A. exochus (A. pectinifemur and A. granulatus, respectively) (SOARES \& SoARes 1984), here revalidated, and A. rhinoceros, transferred from Gonyleptinae. Thus, Acrogonyleptes is defined by the following unambiguous synapomorphies: 1) main tubercles in mesotergal area III fused at base [13], 2) mesotergum granules with heterogeneous sizes and shapes [27], 3) narrow distal concavity of the ventral plate of the penis [63], 4) ventral plate of penis with large lateral lobes [64]. Using DELTRAN, 5) the distal prolateral armature of female femur IV can also be considered a synapomorphy [54], even though it is also present in two basal species of Hernandaria (H. scabricula and $H$. armatifrons).

The second main clade of the subfamily includes Multumbo (with two species, DaSilva \& Kury 2007), which is a sister genus of the clade composed by genera Piassagera (monotypic) and Pseudotrogulus (five species). This second main clade is composed of harvestmen without sexual dimorphism on leg IV, except Multumbo dimorphicus. The placement of this species within this clade results in an ambiguous loss of sexual dimorphism on leg IV and is extremely interesting from an evolutionary point of view (see discussion in "General patterns in character evolution").

Pseudotrogulus includes three previously described and two new species (P. telluris, P. mirim, P. funebris, P. pagu sp. nov., and $P$. trotskyi sp. nov., respectively). The non ambiguous synapomorphies for the genus are: 1) dark markings at area angles [18];2) ventral coxa IV and posterior border of the stigmatic area strongly granulose [32]; 3) leg I with strong ventral tubercles [46] (convergent in Hernandaria); 4) loss of sexual dimorphism in basitarsus I [47], 5) leg III with only six tarsomeres [49], and 6) sparse ventral tubercles on female femora II-IV [52]. Pseudotrogulus trotskyi sp. nov. is placed more basally inside the genus and shows a slightly different facies. The remaining four species present six non ambiguous synapomorphies, and ten under ACCTRAN optimization, that differentiate them from it. This pattern in the Multumbo+ group, with Piassagera brieni sister to Pseudotrogulus, and P. trotskyi sister to the remaining four species, creates certain difficulties in the taxonomic classification. Pseudotrogulus trotskyi sp. nov., differing from all remaining species of the genus (see genus diagnosis in Taxonomy), could be described in a new genus. Synonymizing Piassagera with Pseudotrogulus, thus defining the genus as having no sexual dimorphism on leg IV, would also be an alternative. The first alternative would be prejudicial because it involves creating a monotypic genus which would be followed by another monotypic genus, Piassagera, causing loss of phylogenetic information. On the other hand, placing Piassagera brieni in Pseudotrogulus, considering that the former has unique and strong conspicuous autapomorphies, would ignore a recommendation of the International Code for Zoological Nomenclature (ICZN, 1999) regarding the name stability. Thus, we preferred to describe $P$. trotskyi sp. nov. in Pseudotrogulus and maintain Piassagera brieni as a monotypic genus.

The non-ambiguous synapomorphies which support Hernandariinae are: 1) a single ozopore on each side (as opposed to the two observed in the remaining Gonyleptidae) [7]; 2) a pair of large median apophyses on the anterior margin of dorsal scute [9]; and 3) high density of body granulation [28]. Some ambiguous characters are synapomorphic under ACCTRAN optimization: 4) convergent median apophyses on the anterior margin of dorsal scute [10] (reversion in Multumbo); 5) five tarsomeres on leg I (reversion in Multumbo) [48]; and 6) basal setae of the ventral plate arranged in an oblique row [65] (reversion in Multumbo dimorphicus and Pseudotrogulus). Under DELTRAN optimization: 7) the camouflage with debris [8] can be considered synapomorphic for the subfamily. Some specimens of Mischonyx can also present a slight camouflage, but we cannot say if it is homologous with the available data.

When revalidating the subfamily, Soares \& SOARES (1984) pointed out some of its diagnostic characters. The only one that was corroborated by this phylogenetic analysis was "(...) body covered with small granules, almost always densely distributed (...)" [28]. Many characters cited by the authors were removed from the diagnosis of Hernandariinae due to the placement of Multumbo in the subfamily. Of the characters cited by Firmo \& Pinto-DA-Rocha (2002), only the camouflage with debris was maintained as a synapomorphy, while the other characters are either shared with part of the outgroup or not shared by all the Hernandariinae.

Pinto-DA-Rocha (2002) and Firmo \& Pinto-DA-Rocha (2002) related Hernandariinae to Sodreaninae, Caelopyginae and Progonyleptoidellinae based on the pedipalp with biconvex tarsi and two ventral rows of setae. The first character appeared convergently only in the Acrogonyleptes rhinoceros+ group while the second is similar to the pattern observed in many Gonyleptinae. Thus, the grouping of these four subfamilies was not corroborated by the present phylogenetic analysis. Nevertheless, PinTo-Da-Rocha (2002), Kury \& Pinto-DA-Rocha (1997) and KuRY (1992) point towards the relationship between these 
four subfamilies and Gonyleptinae, based mainly on the general pattern of the penis and palp. In the present hypothesis, Hernandariinae seems to be related to these subfamilies, even though only two species of other Gonyleptidae subfamilies were used in the analysis. The Gonyleptinae genus Mischonyx has a facies similar to Hernandariinae species with males presenting an armed leg IV, and its placement as sister taxon of Hernandariinae is supported by: 1) armature of ocularium directed forward [3]; 2) the large lateral apophysis on the anterior margin of dorsal scute [11]; and depending on the optimization, 3) the camouflage with debris [8] (under ACCTRAN). This is not the first evidence pointing towards the polyphyly, or at least paraphyly, of Gonyleptinae (PINTO-DA-Rocha 2002, KuRY \& PINTO-DA-Rocha 2007), that can currently be defined by several taxa placed basally in this clade of five derived Gonyleptidae subfamilies (Gonyleptinae, Hernandariinae, Sodreaninae, Caelopyginae, Progonyleptoidellinae).

\section{General patterns in character evolution}

The structures that most contributed with informative characters in this analysis were the ornamentation and armature of the dorsal scute and free tergites (30 out of 67 characters). Structures such as the penis or the armature of male leg IV, traditionally associated to high phylogenetic values, represented only few characters. The penis is highly homogeneous and conservative, even similar to the basic pattern observed in Gonyleptinae, showing greater autapomorphic modification at the species level. Thus, only six characters associated to penis morphology were used in this analysis. Furthermore, these few characters have high retention index values ( $\mathrm{ri}=0.7,0.77$, $0.5,0.6,0.66$, and 1) and, of their 32 steps, only six are synapomorphies of species level relationship, depicting a high phylogenetic signal for penial structure at the intergeneric-level. Thus, as structures fully related with sexual selection, changes in penial morphology are constrained "per se". Slightly autapomorphic changes would be related to speciation processes, but with maintenance of a general pattern.

All characters associated to sexually dimorphic armature of male leg IV presented equal or below 50\% retention indexes (RI of chosen tree was $68 \%$ ). Although it is possible to recognize species by this armature, proposing homologies between them is difficult due to the large number of autapomorphies. The increase in the number of granules and tubercles in Hernandariinae occurs together with the camouflage of debris. These characters render an irregular appearance to these animals, which can be often confused with small dirt pellets or any other debris on the substrate, especially if displaying thanatosis for defense (Fig. 176). In addition, they present a reduction of the complex ozopore region, with a single ozopore on each side, reduction of the size of the aperture (Fig. 174) and a characteristic type of emission: flowing through the ventral channels of the anterior coxae to the oral region (SOARES \& SOARES 1984, Hara \& GNASPINI 2003). These characters might be related to the micro habitat in which these animals live, always in the soil, in litter and with cryptic habits. Nevertheless, the coincidence of these characters and few others, such as the strengthening of leg I and the anterior part of the body, might be evidence of adaptation to this type of environment. The camouflage with debris appeared several times independently in harvestmen, in species of Eupnoi Sclerosomatidae, Dyspnoi Trogulidae, Laniatores Podoctidae, Triaenonychidae (GNASPINI $\&$ Hara 2007) and in the Gonyleptidae subfamily Ampycinae (Kury 2003), and Pachylinae Ceratoleptes proboscis Soares \& Soares, 1979 (pers. obs.).

Hernandariinae also show an interesting evolution of sexual dimorphism. Many species show dimorphism in the ornamentation of the mesotergum, basitarsus I and leg IV. In the mesotergum, most females of the Acrogonyleptes + Hernandaria clade maintain the condition of having smaller tubercles in area III than those of males [16], a primitive state also present in the Gonyleptinae included in the cladistic analysis. This same clade is supported by the posterior margin and free tergites more armed in females than in males (with more derived reversals) ([33], Figs 180 and 181). In another evolutionary step, some species later acquired dimorphism in the ornamentation of the lateral margins ([19], Figs 180 and 181), also more armed in females. The latter two characters, despite appearing independently in Hernandariinae, are also observed in other Gonyleptidae taxa (e.g., Ogloblinia, Acanthogonyleptes, and Goniosomatinae). The stronger armature of the posterior part of the female body seems to compensate for the lack of armature on leg IV, when compared to the male. Many harvestmen of the family Gonyleptidae use legs IV to press against the posterior part of the body as a defense mechanism (GNASPINI \& HARA 2007).

The armature of male leg IV, characteristic in Gonyleptidae, is lost in the Multumbo+ group. In the phylogenetic hypothesis herein proposed, this loss is ambiguous due to the position of Multumbo dimorphicus (sexually dimorphic), within this large clade ([53]) (Fig. 1). There are two competing hypotheses we can propose: in a first transformation hypothesis, two independent losses of dimorphism occurred (under DELTRAN), one autapomorphically in Multumbo terrenus and another in Piassagera + Pseudotrogulus. Nevertheless, two independent losses in species so closely related seems unlikely, since in Gonyleptidae the loss of sexual dimorphism of leg IV is only known to occur in three species of Progonyleptoidellinae, in four species of Caelopyginae (Thereza spp.), and in Hernandariinae. A second hypothesis would be a single loss occurring at the base of the Multumbo+ group, with a reversion in Multumbo dimorphicus. This hypothesis does not seem to be the most probable either, since the leg IV armature in the male of $M$. dimorphicus greatly resembles the basic pattern observed in more derived Gonyleptidae, with a large and branched external apophysis on coxa, a dorsobasal apophysis and strong retrolateral spines on femur. The differentiated armature on male leg IV seems to have appeared at a more inclusive level within Laniatores, with a change towards 
stronger and more characteristic armature in Gonyleptidae (KuRY \& PinTo-DA-Rocha 2007). This character has proven to be an important criterion for sexual selection, since males of some species of the family use the leg armature for mating territory disputes (Machado \& Macías-Ordóñez 2007b; Willemart et al. 2009). Thus, the conservation of this special characteristic is motivated by a very strong selective pressure, causing the loss of this dimorphism to be a very important modification. The implausibility of the homoplasy observed in this transformation can be explained by complex genetic processes that facilitate this loss, such as pleiotropy. In this case, a single mutation changes the whole group of characters related to the armature of male leg IV and a reversion could occur in this same manner. Under a cladistic approach there is no sense in differentiating the origins of evolutionary changes, since the different states, observed from the similarity between structures, evidence these changes. Nevertheless, the phylogenetic results, such as the loss of sexual dimorphism of male leg IV, can stimulate the greater understanding and interpretation of these changes under an evolutionary and molecular approach.

The male basitarsus I is inflated in most Progonyleptoidellinae genera (Kury \& PINTO-DA-Rocha 1997), as well as in the Gonyleptinae and Sodreaninae used as outgroups in this analysis. In Hernandariinae it is maintained in Multumbo and Piassagera brieni and evolves secondarily in Pseudotrogulus funebris and Hernandaria zumbii. It is the only type of dimorphism observed in Multumbo+ (except M. dimorphicus) and virtually any type of sexual dimorphism in external morphology is lost in Pseudotrogulus mirim, P. telluris and P. pagu.

In addition to sexual dimorphism, several species show a great size variation in adult males. This difference seems to be more accentuated in the above mentioned secondary sexual characters, with larger males presenting a much stronger armature of leg IV, even when taking into account body size. This variation was observed in several Grassatores taxa (GNASPINI et al. 2004), an infra-order of Laniatores, and can be due to the occurrence of two adult instars (GNASPINI et al. 2004) or different reproductive strategies (MACHADO et al. 2009) caused by territorial disputes between males (Machado \& MaCíAs-OrdóŃEZ 2007b).

\section{Cladistic analysis}

The high density of granules [21] and camouflage with debris [6] are synapomorphies that support Hernandariinae, resulting in an extremely rugged tegument, enhancing the possibility of individual variations in the absence/presence and size of each elevation. In the present analysis, the intraspecific polymorphism which occurs in the ornamentation of the dorsal scute, free tergites and apophysis of the anterior margin of the prosoma led to a great difficulty in coding these characters. This polymorphism is associated, in the literature, to an increase in the number of homoplasies in the analysis, caused by phenotypic, environmental or epigenetic variations, by undersampling of some species or by the introduction of re- versals caused by non fixed alleles (WIENs 1995, KorNEt \& Turner 1999). Амовim et al. (1993) used "syntrepty event" to indicate the appearance of an allele within a lineage, and "synapousy" for its fixation. In a phylogenetic analysis, the definition of primary homology of a polymorphic character might not take this difference into account, considering synapomorphies that might not be fixed within the lineage, and thus revesals occur, as "soft reversals" (KoRnet \& TURner 1999).

In addition to coding two states for polymorphic cells (polymorphic coding, Kornet \& TURNER 1999), the solution for great part of this problem was to generalize the variation in some structures, erecting characters that would cover interspecific variations without including intraspecific polymorphisms that occur throughout the family. This was the case in characters $15,20-22,25,27,28,34-39,57$ and 59 . This type of coding goes against the proposition of absent/present characters for each structure. What was termed composite (WILKInson 1995) or reflective data set (Pogue \& Mickevich 1990), tries to represent, in a more realistic manner, the variation found in nature and in structure modification processes, without reducing it to several, usually interdependent, binary characters (Pogue \& Mickevich 1990). The codification of the above mentioned characters in the present study forms complexes that, as well as reducing the problems related to polymorphisms, guarantee their independence. An over-weighting error for some phylogenetic transformations could occur if the coding of separate characters for each structure or elevation was used.

Thus, 14 ordered multistate characters were proposed: 7 , $9,11-15,17,20,28,31,48,49$ and 64 . For these characters similarity evidences between the ordered states was observed, with similar states being closer to each other in a priori ordination. This similarity could be treated as separate characters, transforming a single multistate character in few binary characters, maintaining the same information evidenced by the primary homology. In any case, a priori observation is maintained as evidence to be contrasted with other characters, testing the convergence between them. Many authors defend this type of coding by including several inapplicable cells in the analysis, consequence of the coding of absent/present followed by a character of the present structure, and by the more realistic coding discussed in the previous paragraph (Pimentel \& Riggins 1987, Pogue \& Mickevich 1990, Lipscomb 1992, Wilkinson 1995, STrong \& Lipscomb 1999).

To observe the consequences of character ordination over the obtained topology, an additional analysis was carried out with all characters unordered. This analysis resulted in 24 most parsimonious tress $(\mathrm{L}=274, \mathrm{ci}=.35$, ri $=.66)$, drastically reducing the resolution of the phylogenetic relationships (consensus: Fig. 2). Character weighting was performed following this analysis with successive weighting (FARRIS 1969) and implicit weighting (Goloboff 1993). Each analysis resulted in a single tree, independently of the weighting criterion (Figs 2-12). In all cases, the genera and subfamily remained monophyletic. 
The results obtained by successive weighing (Figs 3 and 4$)(\mathrm{L}=$ 163.13735 and $\mathrm{L}=162.56235$ ) are very similar to those obtained with character ordination, differing only in the relationship between Pseudotrogulus funebris and P. pagu. Under implied weighting, with $\mathrm{k}=3$ to 6 (Figs 5 and 6) (fit $=26.54899$, $22.88870,20.16048,18.03811$, respectively), only the relation- ships within Acrogonyleptes, Hernandaria and Pseudotrogulus were different, maintaining the relationship amongst genera. Under concavity indexes 1 and 2 (Figs 7 and 8) (fit $=39.68929$, 31.66501), Multumbo is sister to all Hernandariinae. Thus, under the character reliability criterion (FARRIS 1969, CARPENTER 1994), even with the loss of information brought about by the

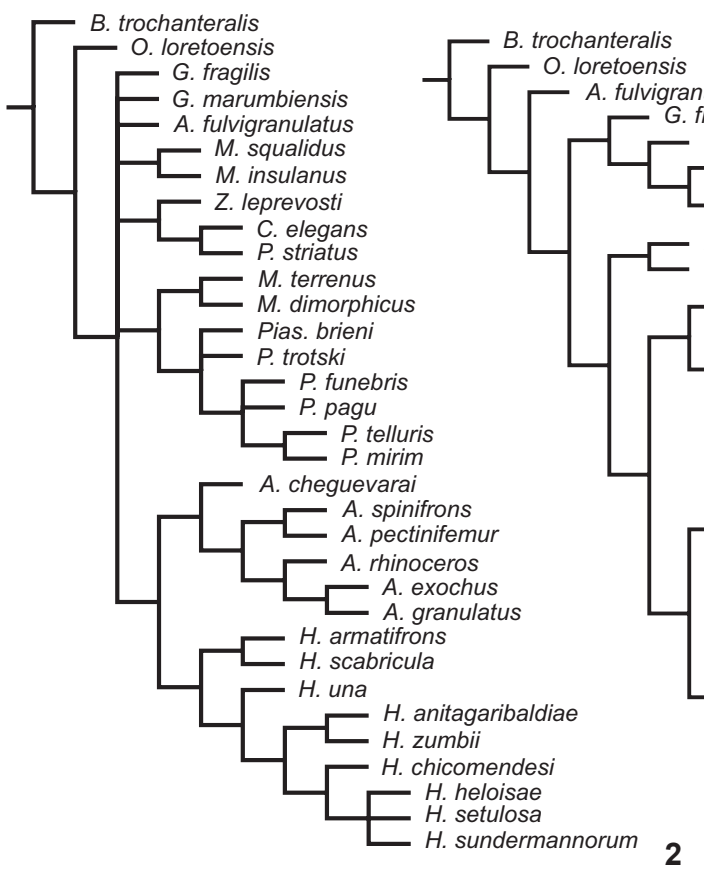

Figures 2-4. Cladograms using non-ordered characters: (2) strict consensus of 24 most parsimonious trees; (3) succesive weighting using highest retention indexes (ri) among 24 trees; (4) same, using lowest retention indexes.

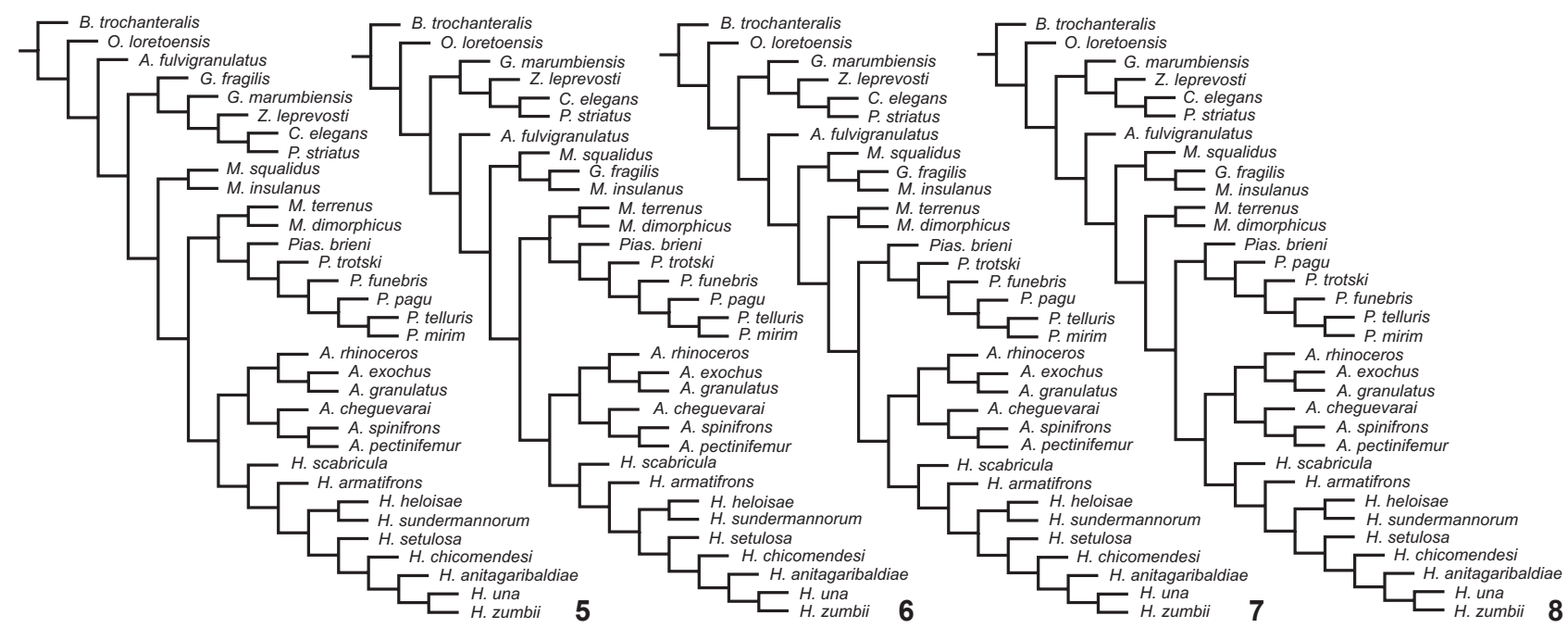

Figures 5-8. Cladograms using non-ordered characters under different implicit weighting: (5) concavity 4,5 or 6 ; (6) concavity 3 ; (7) concavity $2 ;(8)$ concavity 1. 
use of unordered characters, the basic topology and the monophyletism of the taxonomical categories were the same as in the chosen hypothesis (Fig. 1). The weighting analysis was carried out using the original matrix, with ordered characters, yielded the same results as all other analyses (Figs 9-12) (fit = 18.89532, 21.20016, 24.16013, 28.12835, 33.71659, 42.46901, concavity indexes 6 to 1 , respectively). As a result of the suc- cessive weighting, we obtained the hypothesis with Hernandaria heloisae as sister species to $H$. setulosa $(\mathrm{L}=168.05412)$, just the same as one of the two trees obtained using equal weights (Fig. 1). Thus, even with a relatively low Bremmer index support for most taxa (Fig. 1), the analysis robustness was corroborated by the different weightings analyses, that is, by those characters with greater phylogenetic signal.

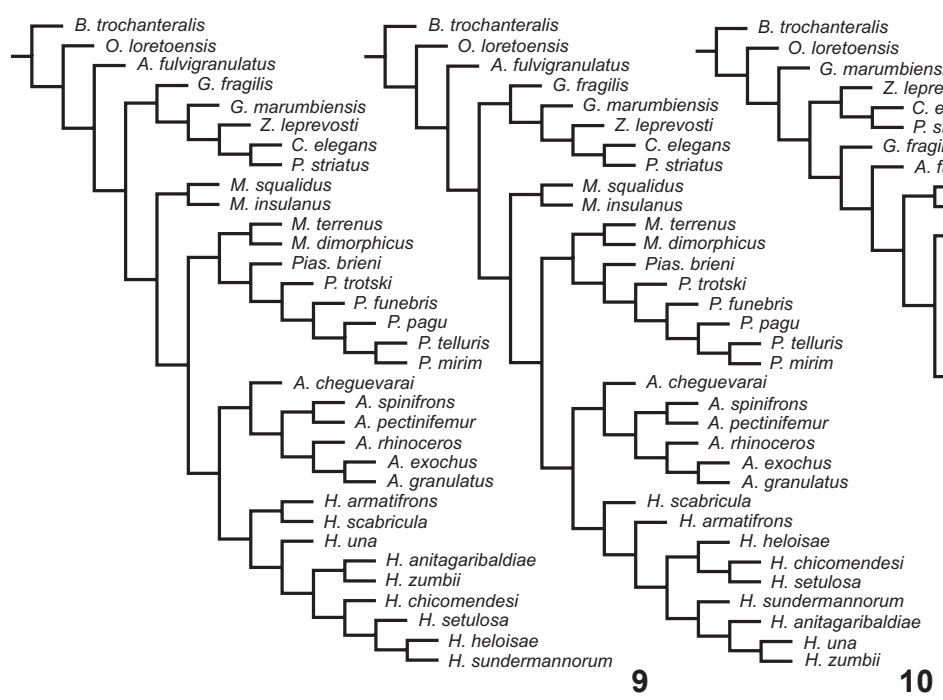

Figures 9-12. Cladograms using 14 ordered characters under different implicit weighting: (9) concavity 6; (10) concavities 3,4 or 5; (11) concavity 2 ; (12) concavity 1.

\section{Taxonomy}

The descriptions, diagnosis, key for identification and taxonomical changes proposed for genera and species of the Hernandariinae are presented below.

\section{Hernandariinae Sørensen, 1884}

Hernandaroidae Sørensen, 1884: 598 [desc]; 1895: 1 [cit]; Kury, 2007: 162 [cit].

Hernandariinae Roewer, 1913: 460 [redesc, key]; 1923: 582 [redesc, key]; 1931: 159 [syst, key]; 1943: 13, 14, 66 [cha, syst]; MelloLeitão, 1926: 366 [key]; 1930b: 211 [syst]; 1949: 9, 13 [syst, key]; Kästner, 1937: 389 [cit]; Soares \& Soares, 1949: 221 [cat, redesc, key]; 1984: 302 (reval.) [redesc, key]; 1985b: 16 [cit]; Ringuelet, 1955a: 291 (syn. Pachylinae) [syst]; H. Soares, 1972: 68 [cit]; Kury, 1994: 97 [cit]; 1997: 2 [cit]; Kury, 2003: 140 [cat]; Pinto-da-Rocha \& Giribet, 2007: 91 (tab. 4.1) [cit]; Kury, 2007: 164, 167 [cit]; Kury \& Pinto-da-Rocha, 2007: 196, 197 (fig. 4.29.h), 198, 199, 203 [cit], 202 [key], Curtis \& Machado, 2007: 283 [biol]; Gnaspini \& Hara, 2007: 393 [biol].

Hernandariinas Mello-Leitão, 1932: 129 [redesc, key].

Hernandariidae Sørensen, 1932: 280 [redesc, key]; Kury, 2007: 165 [cit].
Apembolepheninae (mispelling) Mello-Leitão, 1930b: 212 [desc]; 1933b: 149 [redesc]; 1935: 95, 111 [cat, key]; H. Soares, 1972: 68 [cit].

Apembolephaeninas Mello-Leitão, 1932: 416 [desc].

Apembolephaeninae Kästner, 1937: 389 [cit]; Canals, 1943: 1

(syn. Pachylinae) [syst]; Kury, 1997: 2 [cit]; Soares \& Soares, 1984: 302 (syn. Hernandariinae) [syst].

Diagnosis. Anterior margin of prosoma with one median pair of separated convergent apophyses, or only one apophysis; with 2-3 inner apophyses (simple or bifid) at the corners. With one main pair of higher tubercles behind ocularium and areas I-III (more conspicuous). Only one ozopore. Lateral margin, posterior margin and free tergites with one row of higher tubercles. Dense granulation over the whole body. Camouflage with debris on body and legs (except Piassagera brieni). Basichelicerit with scattered granules on bulla. Pedipalp: trochanter with three high ventral tubercles, some smaller in dorsal side; femur unarmed with one ventro-basal tubercle and some scattered granules. Coxae I-III with one ventral row of longitudinal tubercles decreasing in size from coxa I to III. Trocanthers with three larger ventral tubercles and some smaller scattered tubercles. Legs with rows of tubercles, decreasing in size distadly. Distitarsi 3-segmented, small tarsal process. Pe- 
nis: ventral plate covered ventrally with short hairs, with one apical concavity; three long apical setae in longitudinal row, two smaller apical setae more ventrally placed, one median very small and four basal setae; glans with ventral process bearing flabellum; glans with or without dorsal process.

For genera with sexual dimorphism on leg IV (male): External apical apophysis of coxa IV with two apical branches. Trochanter granulated with longer basal external apophysis and median internal apophysis. Femur IV strongly armed. Femora II-III and tibiae I-IV with ventral tubercles increasing in size apicad. Female differs from male by lack of apophyses on leg IV and weaker femur armature.

\section{Key for genera of Hernandariinae}

1. Median pair of apophyses on anterior margin of dorsal scute separated, distance between their bases larger than apophyses diameter; tarsus I 6-segmented; with longitudinal mark which lacks pigment, in dorsal scute, in similar fashion to the transversal mesotergal sulcus (Fig. 92) .... Multumbo

1 '. Median apophyses on anterior margin close to each other, convergent or single; tarsus I 5-segmented; mesotergal areas II-III (or I-IV) without mark such as inMultumbo (Fig. 74)..2

2. Sexual dimorphism on leg IV absent; leg IV straight and unarmed 3

2'. Sexual dimorphism on leg IV present; male leg IV strongly armed; female femur IV armed or if unarmed, curved inwards .... 4

3. Huge densely granulate spine on free tergite III (size similar to dorsal scute length); entire body covered with whitish/ yellow granules; camouflage with debris absent (Fig. 84)... Piassagera

3'. Free tergite III with spine much shorter than dorsal scute or absent (Fig. 80); whitish/yellow granulation, if present, does not cover all of dorsal scute; camouflage with debris may be present . Pseudotrogulus

4. Main pair of tubercles on mesotergal area III far from each other (Fig. 39); four mesotergal areas (Figs 18 and 22) ..... .. Hernandaria

4'. Main pair of tubercles on area III fused or with tubercles very close to each other (mainly on females) (Fig. 66); three mesotergal areas (Fig. 61) Acrogonyleptes

\section{Hernandaria Sørensen, 1884}

Hernandaria Sørensen, 1884: 598 [desc]; 1895: 1 [cit]; 1932: 281 [key]; Roewer, 1913: 461 [redesc]; 1923: 582 [redesc]; 1931: 159 [key]; Mello-Leitão, 1926: 366 [key]; 1930b: 211 [syst]; 1932:130 [redesc, key]; Kästner, 1937: 389 [cit]; Soares \& Soares, 1949: 222 [cat, redesc, key]; Ringuelet, 1955a: 291 [syst]; 1955b: 2 [syst];; 1957: 19, 25 [cit]; 1959: 322 [redesc]; 1963: 42 [redesc]; Soares \& Soares, 1984: 303 [redesc, key]; 1985b: 16 [cit]; H. Soares, 1972: 68 [cit]; Kury, 2003: 141 [cat].
Apembolephaenus Holmberg, 1909: 38 [desc]; Roewer, 1913: 139 [syst]; 1923: 449 [cit]; 1930: 449 [redesc, syst]; Mello-Leitão, 1930a: 137, 138 [redesc, syst]; 1930b: 211, 212 [syst, key]; 1932: 416 [redesc]; 1939: 624 [syst]; 1949: 9 [syst]; Kästner, 1937: 389 [cit]; Canals: 1943: 1 [cit]; Soares \& Soares: 1954: 236 [cat, redesc, key]; Ringuelet, 1955a: 291 (syn. Hernandaria) [syst]; 1955b: 2 [syst]; 1957: 19 [cit]; Kury, 1997: 2. [cit]. (type species = Apembolephaenus jorgei Holmberg, 1909 , by monotypy).

Apembolephenus (misspelling) Mello-Leitão, 1933b: 149 [redesc]. Proampycus Roewer, 1917: 111 [desc]; 1923: 410 [redesc]; 1929: 184 [key]; Mello-Leitão, 1930a: 138 [cit]; 1930b: 211, 212 [syst, key]; 1932: 214 [redesc]; 1935: 101 [key]; 1939: 624 (syn. Apembolephaenus) [syst]; 1949: 9 [syst]; Kästner. 1937: 389 [cit]; Ringuelet: 1955b: 2 (syn. Hernandaria) [syst]; 1957: 19 [cit]; Muñoz-Cuevas, 1973: 226 [cit]; Kury, 1997: 2 [cit]. (type species = Proampycus spinifrons Roewer, 1917, by monotypy).

Proweyhia Mello-Leitão, 1927a: 414 [desc]; 1932: 279 [redesc]; 1935: 104 [key]; Roewer, 1930: 404 [redesc]; B. Soares, 1944: 165 [syst]; H. Soares, 1945: 219 [syst]; Soares \& Soares, 1947a: 139 [syst]; 1949: 210 [cat, redesc, key]; 1984: 305 (syn. Acrogonyleptes) [syst]. (type species = Proweyhia una MelloLeitão, 1927, by original designation) Syn. nov.

Metaxundarava Mello-Leitão, 1927b: 20 [desc]; 1932: 340 [redesc]; 1935: 105 [key]; 1949: 26 (revalid.) [syst]; B. Soares, 1944: 165 (syn. Proweyhia) [syst]; Soares \& Soares, 1984: 305 (syn. Acrogonyleptes) [syst]. (type species = Metaxundarava heterotypica Mello-Leitão, 1927, by original designation) Syn. nov.

Type species: Hernandaria scabricula Sørensen, 1884, by monotypy.

Diagnosis. Sexual dimorphism: armed male leg IV and posterior margin of dorsal scute and free tergites of female (except $H$. setulosa, similar armature in both sexes). Anterior margin of prosoma with convergent median pair of apophyses, touching each other at apex, larger than apophyses on corners. Prosoma entirely covered by granules, less dense on central part, behind ocularium, and on anterior and lateral margins. Ocularium wider than long, with one convergent pair of small tubercles or large spines. Four areas on mesotergum, area IV can be very narrow, almost unnoticed. Granulation on areas concentrated close to sulci (except $H$. armatifrons and $H$. scabricula) at least on two areas. Main pair of tubercles on area III separated. Similar sized tubercles on lateral margin of mesotergum. Posterior margin of dorsal scute and free tergites of male with similar-sized tubercles or with one median larger tubercle on each segment. Coxa IV (except on male external apical apophysis), stigmatic and genital areas evenly covered by granules. Pedipalpal femur diameter similar to that of other palp articles. Six rows of legs tubercles very regular, except for femur IV. Femur I with strong ventral tubercles (except $H$. scabricula). Tarsus I with five articles. Ventral plate of penis longer than wide, distally with deep and wide concavity, rendering a U-shape, median seta on same vertical line of apical setae. 


\section{Key to the species of Hernandaria}

1. Ocularium with a pair of high and straight convergent spines (Figs 13, 16, 28 and 29) ... 2

1 '. Ocularium with a pair of small and curved tubercles (Figs $33,37,46$ and 55) 5

2. Posterior margin of dorsal scute with one larger median tubercle or spine (Figs 13 and 26); granulation evenly distributed on dorsal scute (Figs 13 and 23) (easier to see if covered with a thin layer of ethanol); corners of anterior margin of prosoma with two single apophyses (Figs 13 and 23) . ... 3

2 '. Posterior margin of dorsal scute with more than one larger tubercle or spine (similarly-sized on male) (Figs 28 and 33); granules concentrated near mesotergal sulci (Figs 18 and $43)$, (easier to see if covered with a thin layer of ethanol); corners of anterior margin of prosoma with two (mesal one bifid) or three apophyses (Figs 43 and 52) ....................... 4

3. Male: pointed external apophysis of coxa IV; single dorsobasal apophysis on femur IV. Female: with row of prolateral large spines on femur IV (Figs 13-17) ......... H. armatifrons

3'. Male: spatulated external apophysis of coxa IV, with truncate apex; dorso-basal apophysis of femur IV bifid. Female: femur IV unarmed (Figs 23-27) ................................. H. scabricula

4. Femur IV longer than dorsal scute length; tubercles of mesotergal areas III and IV rounded and low (Figs 18-22).... H. heloisae

4'. Femur IV shorter than dorsal scute length; tubercles of mesotergal areas III and IV conical and high (Figs 28-32)....

H. setulosa

5a. Female: free tergite III with conical tubercles or spines increasing in size to the middle, larger than tubercles of other free tergites H. una

$5 \mathrm{a}^{\prime}$. Female: free tergite III with similar-sized tubercles, size of tubercles similar to those on other free tergites

$H$. anitagaribaldiae sp. nov.

5b. Male: main pair of tubercles of mesotergal area III rounded, low and larger than those on other mesotergal areas (Figs 33 and 55)

.... 6

$5 b^{\prime}$. Male: conical tubercles on mesotergal area III (Figs 46 and 51)

6. With spines between the median pair of apophyses and those placed in the corners on anterior margin of prosoma; external apophysis of coxa IV and dorso-basal apophysis of femur IV falcate (Figs 52-56) ... H. chicomendesi sp. nov.

6'. Unarmed between median pair of apophyses and those placed in the corners on anterior margin of prosoma; external apophysis of coxa IV and dorso-basal apophysis of femur IV long and with two short branches (Figs 33-38)

.H. una

7. Mesotergal area IV easily seen; length similar to that of area III (Figs 39-42) ........................ sundermannorum sp. nov.
7'. Mesotergal area IV not easily seen (mesotergum seems to have three areas); much shorter than area III (Figs 43 and 48)

8. Main pair of tubercles of mesotergal area III large, larger than other areas; male femur IV with retrolateral-subapical larger spine; external apophysis of coxa IV with acute and backward directed apex (Figs 48-51) .... H. zumbii sp. nov.

$8^{\prime}$. Main pair of tubercles of mesotergal area III similar-sized to those of other areas; retrolateral larger spines on male femur IV median or submedian; external apophysis of coxa IV with middle part thinner and swollen apex (Figs 43-47) .. .. H. anitagaribaldiae sp. nov.

Observation: females of $H$. sundermannorum sp. nov., $H$. zumbii sp. nov. and $H$. chicomendesi sp. nov. are unknown.

\section{Hernandaria armatifrons (Roewer, 1917) comb. nov.}

Figs $13-17,131,132,177,185$

Metagonyleptes armatifrons Roewer, 1917: 135 (fig. 31) [desc]; 1923: 481 (fig. 605) [redesc]; 1930: 360 [key]; Mello-Leitão, 1932: 334 (fig. 211) [redesc]; Soares \& Soares, 1949: 191 [cat]; 1984: 306 [syst].

Acrogonyleptes armatifrons: Soares \& Soares, 1984: 306 [syst]; Kury, 2003: 141 [cat].

Apembolephaenus calcaratus Soares \& Soares, 1945: 371 (fig. 3) [desc]; 1954: 236 [cat]; Pinto-da-Rocha \& Caron, 1989: 1023 [cit]. Syn. nov.

Hernandaria calcarata: Soares \& Soares, 1984: 303 (figs 1-4) [syst]; Kury, 2003: 142 [cat].

Diagnosis. As $H$. scabricula, this species has a homogeneous distribution of granules on dorsal scute, whereas other species of Hernandaria have a high density of granules near sulci of mesotergal areas. It shares high convergent spines on ocularium and unpaired armature on posterior margin and free tergites with $H$. scabricula. Differs from $H$. scabricula by (male) having dorso-basal apophysis of femur IV with single apex, pointed and curved outwards; prolateral spines of femur IV larger than other spines, except for larger subapical retrolateral; and short and pointed apex of external apophysis of coxa IV.

Male redescription. Dorsum (Figs 13 and 16). Corners on anterior margin of dorsal scute with two apophyses of similar size and shape, external forwardly directed. Ocularium with one pair of straight and convergent spines. Dorsal scute homogeneously covered by granules. Mesotergal areas I-III with main pair of rounded tubercles, increasing in size from I to III, plus one paramedian pair of smaller tubercles; IV slightly smaller than III, with two pairs of tubercles similar to those of area I, in a transversal row. Lateral margin with one row of similar-sized tubercles from area I-III. Posterior margin and free tergites with a row of tubercles, one median larger, rounded or conical, similar-sized or decreasing in size from posterior margin to free 

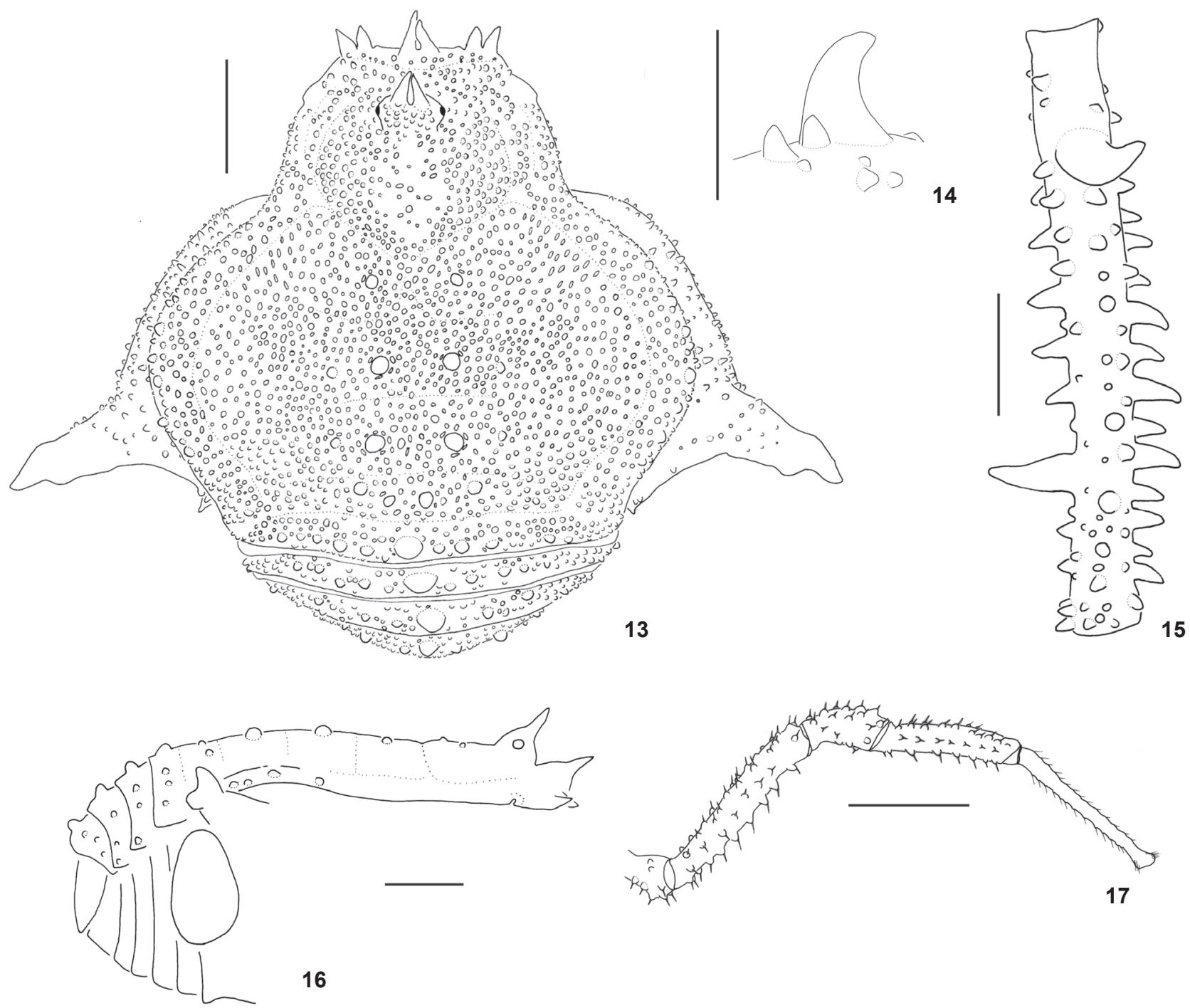

Figures 13-17. Hernandaria armatifrons: (13) dorsal habitus, male (MZSP14760); (14) dorso-basal apophysis of right male femur IV, prolateral view (MZSP15954); (15) right male femur IV, dorsal view (MZSP15954); (16) body, right lateral view, male (MZSP15954); (17) trocanther-metatarsus of right leg I, retrolateral view, male (MZSP14716). Scale bar: $1 \mathrm{~mm}$.

tergite III. Pedipalps. Tibia iili/IiI (iiIi) ectal; Ii/Iii/Iiii (Iiii) mesal. Tarsus IiI ectal; II mesal. Legs (Figs 14, 15 and 17). All leg tubercles high, pointed and directed apicadly (except in leg I) and organized in six longitudinal rows (except in femur IV), larger on venter of femora I-IV and tibiae III-IV. External apical apophysis of coxa IV transversal, short apical branches, pointed dorsally, ventrally much smaller and rounded. Femur IV slightly curved inwards, with one retrolateral row of spines increasing in size, slightly curved frontwards; prolateral spines larger than retrolateral from $1 / 4$ basal until the apex; single dorso-basal apophysis, which is short, pointed and curved outwards. Tarsal formula: 5, 6/8, 6, 6/7 (7). Penis (Figs 131 and 132). Ventral plate with basal setae close to each other in an oblique row, ventralmost much smaller; median seta similar-sized to ventroapical setae, far from apical setae. Stylus with oblique apex and ventro median projections; ventral process with projections on shaft and with losangle flabellum bearing projections on ventral margin. Coloration (Fig. 177). Grayish brown with metatarsi and leg tarsi light brown, yellowish pedipalps. Measurements. Dorsal scute: 4.4-5.7 long; 4.4-5.8 wide; legs: I: 6.78.0, II: 13.1-17.8, III: 10.7-14.2, IV: 14.6-19.7, male femur IV: 3.7-5.0, pedipalp: 3.1-3.9.

Female. It differs from male by: acuminate tubercles and spines on lateral and posterior margins of dorsal scute and free 
tergites; femur IV unarmed, except prolateral row (similar to male). Measurements. Dorsal scute: 4.4-5.9 (5.9) long; 4.1-5.8 (5.8) wide; legs: I: 6.7-8.5 (8.5), II: 11.6-13.6, III: 9.8-12.7 (12.7), IV: 13.1-18.1, pedipalp: 3.2-4.6 (4.6).

Material examined. BrasiL, São Paulo: Santos (mislabeled?), fe (SMFD1328, holotype of Metagonyleptes armatifrons); Pirajú, G.Skuk \& V.X. Silva, 30.III.1996, 1 ma (MZSP29098); Paraná: Teixeira Soares (Rio D'Areia), R. Lange, IX.1944, 1 ma (MHNCI1079, holotype of Apembolephaenus calcaratus); Pinhão (UHE Segredo, Rio Butia), R. Pinto-da-Rocha, \& Lopes, X.1991, 1 ma and 1 fe (MZSP14716); Três Barras do Paraná (Reserva do Rio Guarani), M. Oliveira-da-Silva \& M. Miretzki, X.1998, 1 fe (MZSP17794); ibidem, R. S. Bérnils, G. Montingelli \& R. Lingnau, VIII.1998, 1 fe (MZSP17951); ibidem, F.L. Franco, M. Di-Bernardo \& S.A.A. Morato17.X.1998, 1 ma (MZSP-17823); Foz do Iguaçu (P.N. do Iguaçu), 1 ma (IBSP2948); ibidem, R. Pinto-da-Rocha \& S. Casari, I.1997, 2 ma (MZSP15954); III.2002; General Carneiro (Faz. São Carlos), Borschein \& Arruda, XII.1989, 1 fe (MHNCI6657). Santa Catarina: Joaçaba (Estrada de Concórdia), A. Bonaldo, A. B. Kury \& R. Pinto-da-Rocha, I.1996, 1 ma (MZSP14760). Rio Grande do Sul: Derrubadas (P.E. Turvo), Equipe Biota, I.2002, 1 fe (IBSP5146); Barra do Ribeiro, H. Bischoff, XI.1976, 1 fe (MCN474).

\section{Hernandaria heloisae (H. Soares, 1945) Figs 18-22, 112, 133, 134, 186}

Proweyhia heloisae H. Soares, 1945: 217 (fig. 3) [desc]; Soares \& Soares, 1945: 369 [syst]; 1949: 190 [cat]; Pinto-da-Rocha \& Caron 1989: 1023 [cit].

Hernandaria heloisae: Soares \& Soares 1984: 303 (figs 5-6) [redesc]; Hara \& Gnaspini, 2003: 262 (fig. 3) [cit]; Kury, 2003: 142 [cat]; Braganolo et al. 2007: 393 (dist).

Diagnosis. Closely related to H. sundermannorum sp. nov., differs by having ocularium with one pair of convergent, high spines, with the tips touching each other (low spines in $H$. sundermannorum sp. nov.); pair of tubercles on area IV (two pairs in $H$. sundermannorum sp. nov.); lower density of granules mainly on lateral of areas and lateral margin; curved external apical apophysis of coxa IV (straight in Hernandaria sundermannorum sp. nov.). Differs from other species of Hernandaria by the low density of granules on dorsal scute, small basal curved spine of femur IV and long leg IV (shared with H. sundermannorum sp. nov.).

Male redescription. Dorsum (Figs 18 and 21). Corners on anterior margin of dorsal scute with two apophyses, mesal apophysis can be bifid from the base, or three similar apophyses (type: two apophyses, internal one bifid). Ocularium with a pair of spines straight and convergent. Mesotergal areas I-IV with more dense granulation near sulci; sides of areas and lateral margin with lower density of granules; III with main pair of rounded tubercles on the center of the area, closer to each other than those on other areas; IV with same length of III, with one pair of tubercles on middle of area and more distant from each other than in other areas. Lateral margin with a row of tubercles, increasing in size apicad until area III. Posterior margin and free tergites with a row of conical similar-sized tubercles, or with 1-5 slightly larger tubercles placed in the middle of each tergite (type: posterior margin and free tergite I: 2 , free tergite II: 3 , free tergite III: 5), plus some scattered granules. Pedipalps (Fig. 112). Tibia IIi ectal IIi/Iili (IIi) mesal. Tarsus II ectal and mesal. Legs (Figs 19, 20 and 22). All tubercles of legs acuminated, similar-sized per leg, pointing backwards and organized in six longitudinal rows, except for femur I and IV. Femur I with ventral tubercles slightly larger than the rest of leg I. External apical apophysis of coxa IV almost transversal, slightly curved frontwards, with dorso-apical branch slightly curved backwards, more than twice larger than ventral branch. Femur IV long and straight; with three large median-retrolateral spines and few small scattered spines, basal curved frontwards; dorso-basal apophysis bifid, similar-sized to diameter of femur, internal branch directed upwards and external horizontal branch with straight apex. Tarsal formula: 5, 7/9 (8), 6, 7. Penis (Figs 133 and 134). Ventral plate with basal setae close to each other in longitudinal row on middle of ventral plate; median seta small as ventro-apicalmost setae, at same distance of larger apical setae. Stylus with oblique apex and without projections; ventral process with losangle flabellum bearing projections on ventral margin. Coloration. Uniformly blackish, with yellowish pedipalps, metatarsi and tarsi of legs. Measurements. Dorsal scute: 3.2-5.0 (4.2) long; 3.6-5.0 (4.7) wide; legs: I: 5.5-8.4 (7.1), II: 15.3-22.1 (19.0), III: 10.7-16.1 (13.2), IV: 15.523.2, male femur IV: 4.8-6.8 (6.1); pedipalp: 3.4-4.7 (3.5).

Female. It differs from male by having: tubercles of posterior margin and free tergites larger than those of lateral margin; femur IV with similar-sized tubercles. Measurements. Dorsal scute: 4.5-4.7 long; 4-4.4 wide; legs: I: 7-8.3, II: 17.1-22.4, III: 11.5-14.8, IV: 17.1-22.5; pedipalp: 3.4-4.

Material examined. Brasil, São Paulo: Cotia (Reserva do Morro Grande), Equipe Biota, III.2003, 1 ma (MZSP29091); ibidem, Equipe Biota, III.2003, 1 fe (IBSP); Miracatu (Fazenda Itereí), Equipe Biota, IX.2001, 1 fe (IBSP3598); ibidem, Equipe Biota, IX.2001, 1 ma (IBSP3543); Iporanga (PETAR, Ouro Grosso), Equipe Biota, XI.2001, 1 fe (IBSP4027). Paraná: Curitiba (Barigui), R. Lange, VIII.1944, 1 ma (MHNCI154); ibidem, R.Hertel, XI.1944, 1 ma (MZSP1338); ibidem, Hertel, 1944, 1 ma (MZSP944, holotype of Proweyhia heloisae).

\section{Hernandaria scabricula Sørensen, 1884}

Figs 23-27, 135-137, 185

Hernandaria scabricula Sørensen, 1884: 599 [desc]; 1895: 1 [cit]; Roewer, 1913: 461 [redesc]; 1923: 582 [redesc]; Soares \& Soares, 1949: 222 [cat, redesc, key]; 1984: 305 (figs 7-8) [redesc]; 1985b: 16 [cit]; Ringuelet, 1955a: 291 [syst]; 1955c: 7 [syst]; 1957: 12, 21-23 [cit]; 1959: 325 (figs 1, 4) [redesc]; 1963: 43 [cit]; Capocasale, 1966: 631 [cit]; 1968: 70 [cit]; 2003: 2; Valentinis de Martínez, 1974: 8 [biol]; Kury: 1997: 2 [cit]; Kury, 2003: 142 [cat]; Machado \& Macías-Ordóñez, 

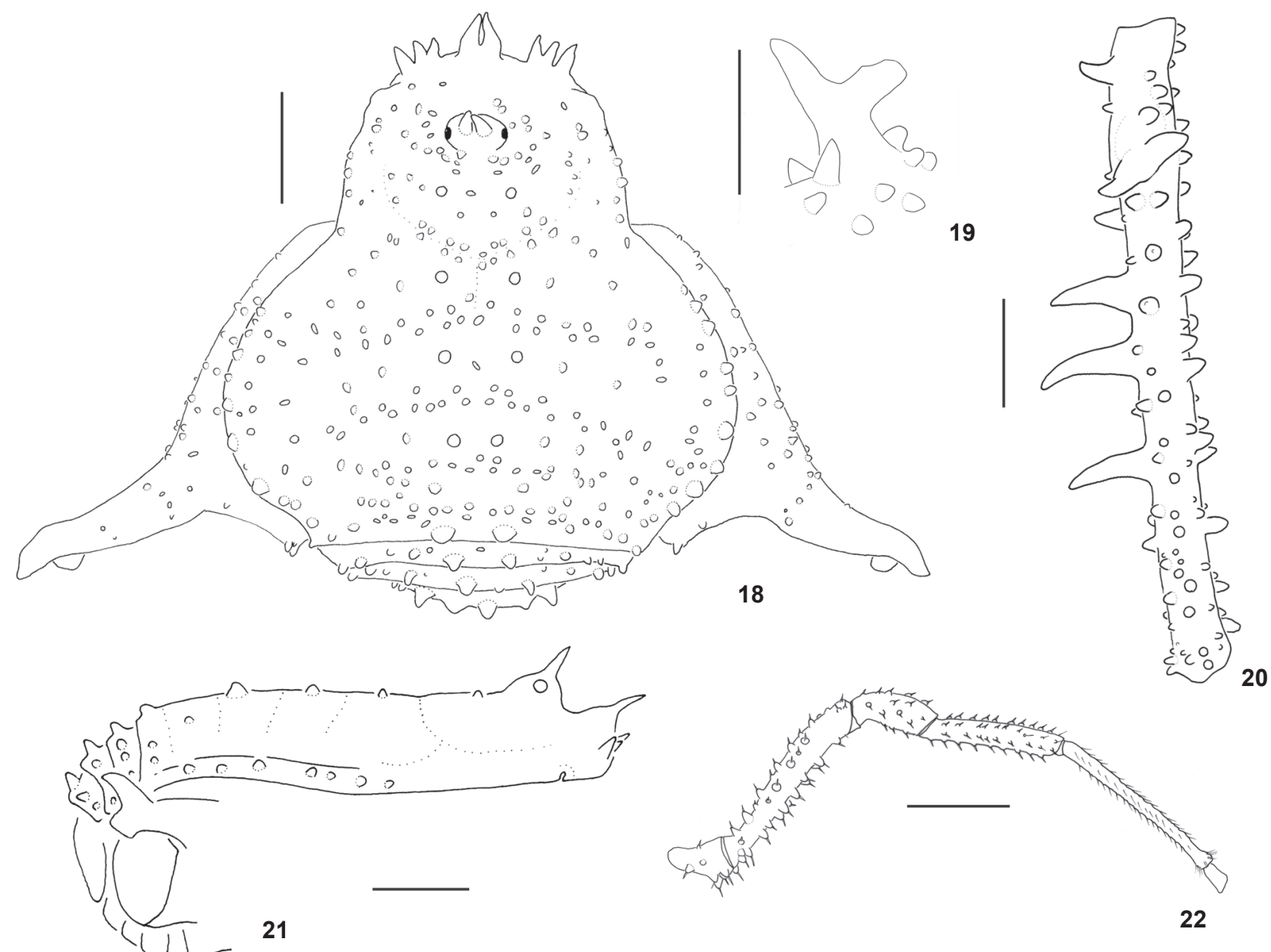

22

Figures 18-22. Hernandaria heloisae: (18) dorsal habitus, male holotype (MHNCI154); (19) dorso-basal apophysis of right male femur IV, prolateral view, holotype (MHNCI154); (20) right male femur IV, dorsal view, holotype (MHNCI154); (21) body, right lateral view, male (IBSP3543); (22) trochanter-tarsus of right leg I, retrolateral view, male (IBSP, Cotia). Scale bar: $1 \mathrm{~mm}$.

2007a: 407 (tab. 11.2) [biol]; Machado \& Macías-Ordóñez, 2007b: 435 (tab. 12.2), 459 (tab. 13.1) [biol].

Apembolephaenus Jorgei Holmberg, 1909: 39 [desc]; Frers, 1917: 405 (fig.) [syst].

Apembolephaenus jorgei: Roewer, 1913: 139 [syst]; 1923: 449 [cit];

1930:449 (fig. 47) [redesc, syst]; Mello-Leitão, 1930a: 139

[redesc]; 1933b: 150 [syst]; 1939: 624 [syst]; Canals, 1936: 61 [biol]; Kästner, 1937: 342 (fig. 427) [cit]; B. Soares, 1945b: 369 [cit]; Soares \& Soares, 1954: 236 [cat]; Ringuelet, 1955a: 291 (syn. Hernandaria scabricula) [syst]; 1955c: 7 [syst]; H. Soares, 1972: 68 [cit]; Kury, 1997: 3 [cit].

Apembolephenus jorgei (misspelling): Mello-Leitão, 1931b: 84 [syst]. Proampycus spinifrons Roewer, 1917: 111 (fig. 16) [desc]; 1923:

411 (fig. 505) [redesc]; Mello-Leitão, 1939: 624 (syn. Apembolephaenus jorgei) [syst]; Ringuelet, 1957: 12 [cit]; $\mathrm{H}$. Soares, 1972: 68 [cit]; Acosta, 1996: 222 [cit].
Diagnosis. It is closely related to $H$. armatifrons sharing a dense granulation on dorsal scute; convergent high spines on ocularium and unpaired armature on posterior margin and free tergites. It differs from $H$. armatifrons by having a bifid dorsobasal apophysis on male femur IV, a much larger spine on male femur IV, with different shape at apex and base; apex of external apophysis of male coxa IV spatule-shaped; lack of one row of prolateral larger spines on female femur IV and only one large spine on posterior margin of female dorsal scute.

Male redescription. Dorsum (Figs 23 and 26). Corners of anterior margin of dorsal scute with two apophyses, similar in size and shape, external apophysis forwardly directed. Ocularium with a pair of straight and convergent spines. Dorsal scute homogeneously covered by granules. Mesotergal areas I-III each one with a main pair of rounded tubercles, slightly increasing in size from I to III, some specimens have one para- 


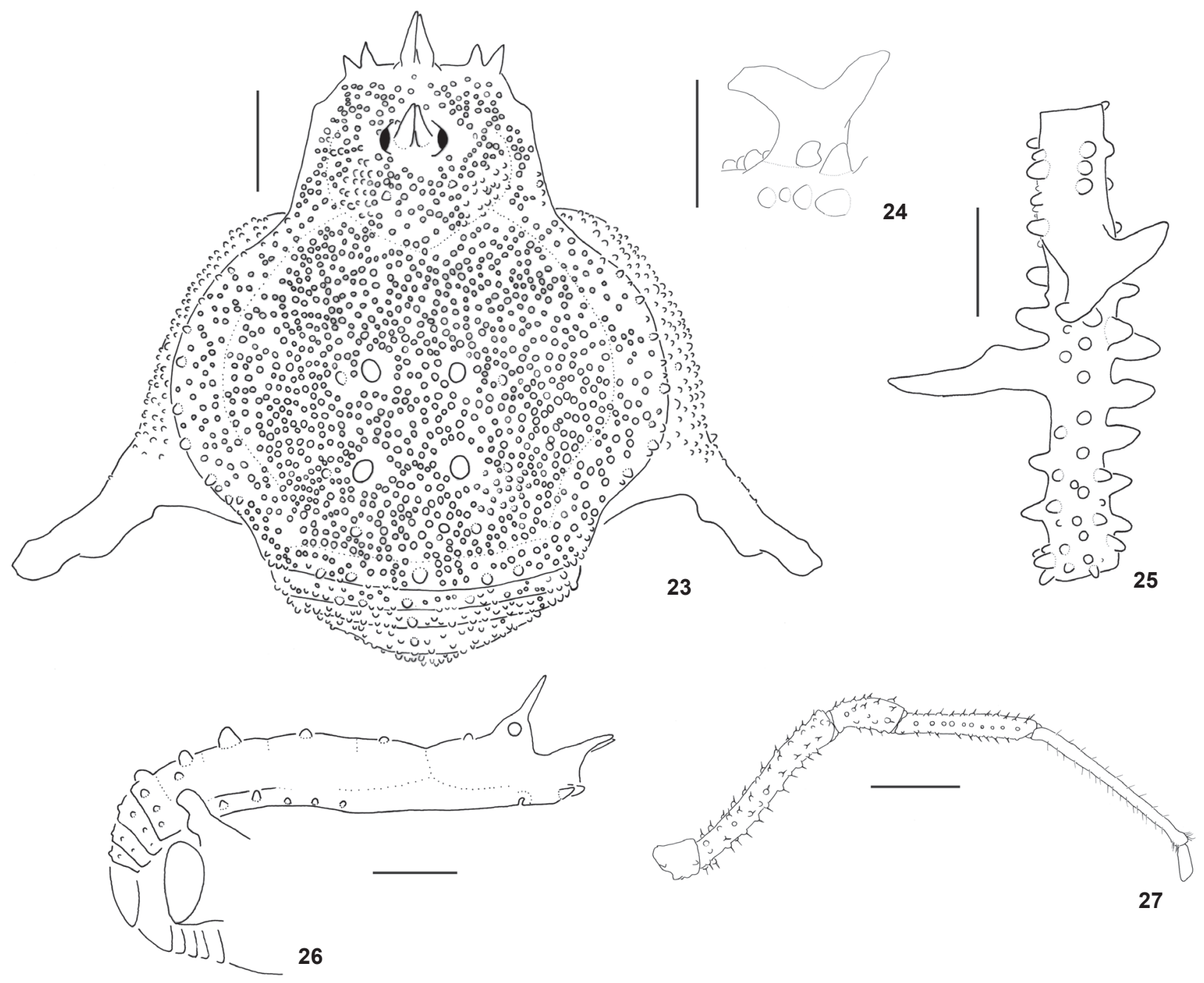

Figures 23-27. Hernandaria scabricula: (23) dorsal habitus, male (SMFD3864); (24) dorso-basal apophysis of right male femur IV, prolateral view (SMFD1311); (25) right male femur IV, dorsal view (MNRJ1415); (26) body, right lateral view, male (MNRJ1415); (27) trochantertarsus of right leg I, retrolateral view, male (MNRJ1415). Scale bar: $1 \mathrm{~mm}$.

median pair of smaller tubercles; IV with same length of III, with two pairs or one pair of tubercles similar to those of I, in a transversal row. Lateral margin with one row of tubercles similar in size to those of areas I-III. Posterior margin and free tergites with one row of rounded tubercles similar in size to those of lateral margin, with one median larger rounded or conical tubercle, decreasing in size from posterior margin to free tergite III or similar in size. Pedipalps. Tibia IIi ectal; Iili mesal. Tarsus IiI ectal; II mesal. Legs (Figs 24, 25 and 27). All leg tubercles high, acuminate and directed apicad, organized in six longitudinal rows, except in femur IV, larger on venter of femora I-IV and tibiae III-IV. Femur I with ventral tubercles slightly larger than tubercles on the rest of leg I. External apical apophysis of coxa IV almost transversal, with large dorso-apical branch spatule-shaped, ventral branch much smaller and rounded. Femur IV slightly curved inwards, with one retrolateral row of spines increasing in size until one large median spine, whose length is more than twice of femur diameter, with a large and straight base, distal half curved frontwards; prolateral spines larger than retrolateral, except the median one, larger on median portion; venter sparsely granulated; low dorso-basal apophysis with similar-sized apical branch, internal branch curved upwards, external branch horizontal, slightly curved downwards. Tarsal formula: 5, 7, 6, 7. Penis (Figs 135-137). 
Ventral plate with basal setae close to each other in almost horizontal row, two ventralmost much smaller; median seta similar-sized to ventro-apical ones, at same line of dorso-apical. Stylus with oblique apex and ventral projections; ventral process with losangle flabellum. Coloration. Lost in ethanol. "Unicolore sordide rubra" (uniformly dirty red) according to Sørensen (1884). Measurements. Dorsal scute: 5.1-5.5 long; 4.8-5.3 wide; legs: I: 7.5-8.7, II: 15.3-17, III: 12-13.4, IV: 15.918, femur IV: 4.2-4.4, pedipalp: 4.1-4.6.

Female. It differs from male by having: acuminate tubercles on lateral margin of dorsal scute; median large spine on posterior margin and free tergites; armature of femur IV similar to other femora. Measurements. Dorsal scute: 5.3-5.9 long; 4.5-5.2 wide; legs: I: 7.6-8.1, II: 14.3-16, III: 11.5-11.7, IV: 15.6-16.4, femur IV: 4.0-4.4; pedipalp: 4.2-4.4.

Material examined. Argentina, Buenos Aires: Buenos Aires, $12 \mathrm{ma}$ and 13 fe (SMFD3864); ibidem (Parque 3 de Frebero), J. Canals, 6 ma and 6 fe, (MNRJ1415); Bahia Blanca, 1 ma (SMFD1311, holotype of Proampycus spinifrons).

\section{Hernandaria setulosa (Mello-Leitão, 1933b)} Figs 28-32, 118, 119

Apembolephenus setulosus (misspelling) Mello-Leitão, 1933b: 149 (fig. 16) [desc].

Apembolephenus setulosos (misspelling): Mello-Leitão, 1935: 111 [cit].

Apembolephaenus setulosus: B. Soares, 1945a: 193 [cit]; 1945b: 369 [cit]; Soares \& Soares, 1954: 237 [cat].

Hernandaria setulosa: Soares \& Soares, 1984: 305 (figs 9-10) [redesc]; Kury, 2003: 142 [cat].

Diagnosis. It differs from other species of Hernandaria by having large and conical tubercles on entire posterior margin and free tergites, larger than other parts of dorsal scute, and by the main pair of tubercles of mesotergal area IV larger than of area III, all conical. It shares very short legs having high tubercles in regular rows with $H$. chicomendesi sp. nov..

Male redescription. Dorsum (Figs 28 and 31). Corners on anterior margin of dorsal scute with two apophyses, internal apophysis apically bifid. Ocularium with one pair of straight, convergent spines. Mesotergal areas I-IV with granulation denser near sulci; III-IV with main pair of high and conical tubercles, slightly larger on IV, and much larger than those of areas I-II; area IV with the same length as III and with one additional pair of paramedian tubercles, smaller than main pair. Lateral margin with granules. Posterior margin and free tergites with one row of conical tubercles much larger than others on dorsal scute; larger tubercles on posterior margin. Pedipalps. Tibia ili ectal; IiI mesal. Tarsus IiI ectal; II mesal. Legs (Figs 29, 30 and 32). All leg tubercles organized in six longitudinal rows, pointed backwards, high and with rounded apex and similar-sized, in each article, except for femur I and IV. Femur I with ventral tubercles slightly larger than tubercles of the rest of the leg. External api- cal apophysis of coxa IV slightly oblique, with short apical branches. Femur IV short, basally thinner; with retrolateral row of spines increasing in size until one larger placed on apical 1/3; larger tubercles on ventro-basal half, on distal prolateral half and at median dorsal region; bifid dorso-basal apophysis, slightly larger than diameter of femur; two branches obliquely directed, internal twice longer than external, rounded apexes. Tarsal formula: 5, 7/8 (8), 6, 6. Penis (Figs 118 and 119). Ventral plate with basal setae close to each other in vertical row, except for ventralmost, at same horizontal line of basalmost; median seta slightly larger than ventro-apical setae, very far from dorsal apical setae. Stylus with oblique apex and without projections; ventral process with losangle flabellum bearing projections on ventral margin. Coloration. Lost in ethanol. "Colorido geral castanho queimado escuro" (General color dark burnt brown), according to Mello-Leitão (1933b). Measurements. Dorsal scute: 4.0-4.9 (4.8) long; 3.5-4.6 (4.4) wide; legs: I: 6-6.6 (6.6), II: 12.913.2 (13.2), III: 8-12.7 (12.7), IV: 12.5-16.5 (16.5), male femur IV: 3.3-4.2 (4.2), pedipalp: 3.2-3.6 (3.2).

Females. Without sexual dimorphism on area III, posterior margin, free tergites and lateral margin of dorsal scute. Leg IV unarmed. Measurements. Dorsal scute: 4.2-4.5 long; 3.9-4.1 wide; legs: I: 5.7-6.1, II: 9.7-11.7, III: 8.5-8.9, IV: 12.1-12.7; pedipalp: 3.0-3.3.

Material examined. BrasiL, Paraná: Cachoeirinha, F. Lange de Morretes, without date, 5 ma and 11 fe (MNRJ26924, 1 ma lectotype and paralectotypes of Apembolephaenus setulosus); Cachoeirinha, F. Lange de Morretes, without date, $4 \mathrm{fe}$ (MNRJ42437). It was not possible to establish this locality at any specific place. "Cachoerinha" means "little waterfall" in Portuguese.

\section{Hernandaria una (Mello-Leitão, 1927) comb. nov. Figs $33-38,138,139,178,188$}

Proweyhia una Mello-Leitão, 1927a: 414 [desc]; 1932: 280 (fig. 170) [redesc]; Roewer, 1930: 405 [redesc]; B. Soares, 1944: 165 [syst]; 1945b: 364 [cit]; H. Soares, 1945: 219 [syst]; Soares \& Soares, 1949: 210 [cat].

Acrogonyleptes unus: Soares \& Soares, 1984: 308 (figs 17-18) [redesc]; Hara \& Gnaspini, 2003: 258, 259, 264 (figs 3, 30 e tab. 3) [biol]; Kury, 2003: 141 [cat].

Metaxundarava heterotypica Mello-Leitão, 1927b: 20 [desc]; 1932: 341 [redesc]; Roewer, 1930: 401 [redesc]; B. Soares, 1944: 165 (syn. Proweyhia una) [syst].

Diagnosis. Differs from other species of Hernandaria by having a transversal, wide and slightly curved external apophysis of male coxa IV; several tubercles concentrated at ventromedian region of male femur IV; high dorso-basal apophysis of male femur IV, which has short apical branches; main pair of tubercles on male mesotergal area III of larger diameter than of other areas (also present in H. chicomendesi sp. nov.); area IV inconspicuous. 

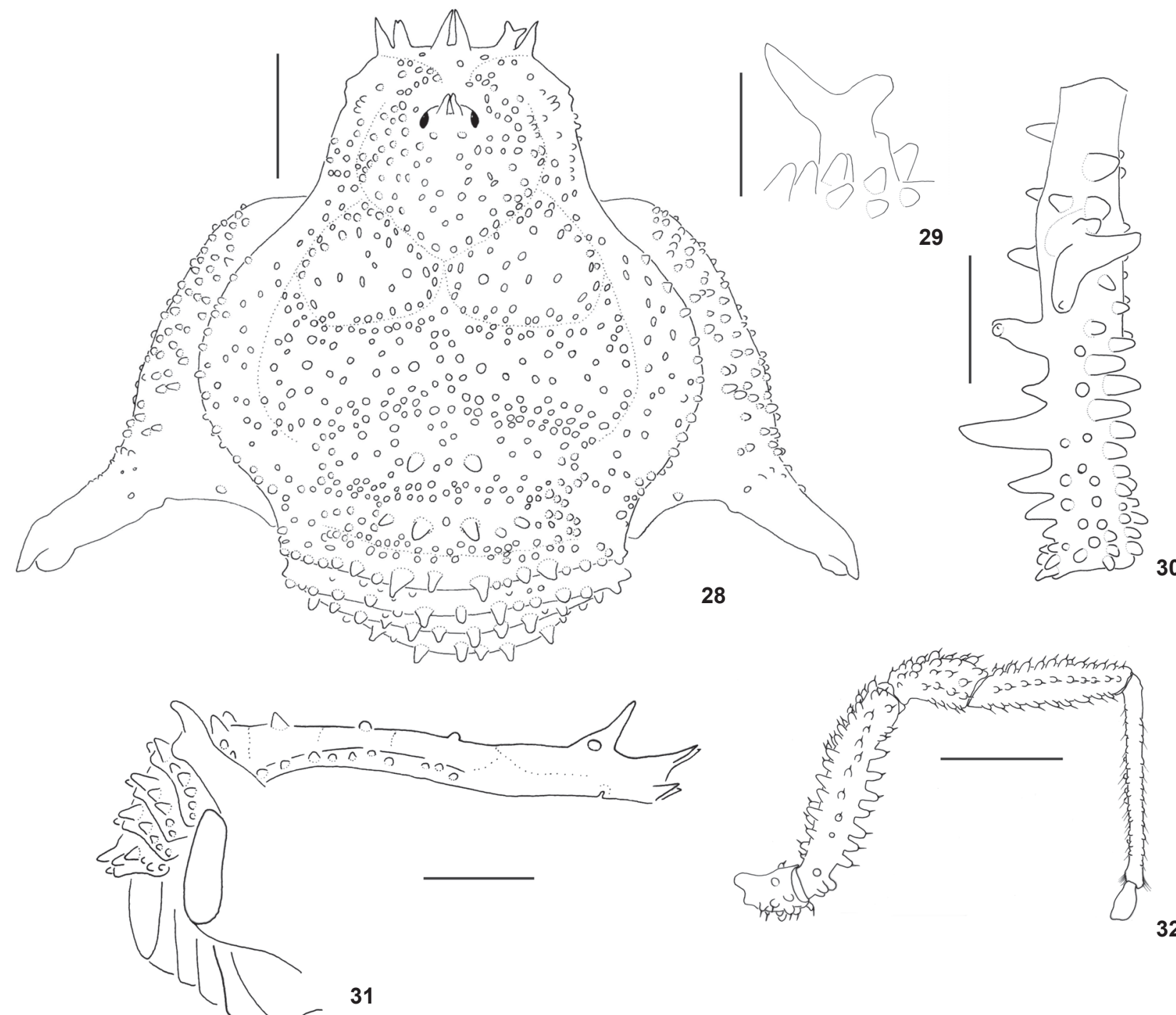

32

Figures 28-32. Hernandaria setulosa, male lectotype (MNRJ26924): (28) dorsal habitus; (29) dorso-basal apophysis of right male femur IV, prolateral view; (30) right male femur IV, dorsal view; (31) body, right lateral view, male paralectotype (MNRJ26924); (32) trochanter-tarsus of right leg I, retrolateral view, male lectotype (MNRJ26924). Scale bar: $1 \mathrm{~mm}$. !mesmo bicho?

Male redescription. Dorsum (Figs 33 and 36). Corners on anterior margin of dorsal scute with two apophyses, internal apophysis sagitally or horizontally bifid or three similar apophyses (holotype: two with horizontal bifurcation from middle of apophysis). Ocularium with a pair of tubercles close to each other, weak, blunt apex and slightly curved inwards. Mesotergal areas I-II with denser granulation near sulci; IV with almost uniform density of granulation; I-III with a main median pair and additional 1-2 submedian tubercles. Area I with anterior and lateral granules longitudinally elongated; III with main pair of larger rounded tubercles, depressed, closer to posterior margin than sulcus III; IV narrow, inconspicuous, except for its main pair of tubercles close to pair of area III. Lateral margin with lower density of granules; one row of similar-sized tubercles, scattered in all its extension. Posterior margin and free tergites with one row of similar-sized rounded tubercles or 1-3 slightly larger median tubercles (holotype: similar), and some scattered granules. Pedipalps. Tibia IIi ectal IIi/II; (II) mesal. Tarsus IiI ectal; II mesal. Legs (Figs 34, 35, 37 and 38). All leg tubercles organized in six longitudinal rows of similar-sized tubercles pointed distad, in each article, except for femur I and IV. Femur I with larger ventral tubercles on median region, twice larger than others. 

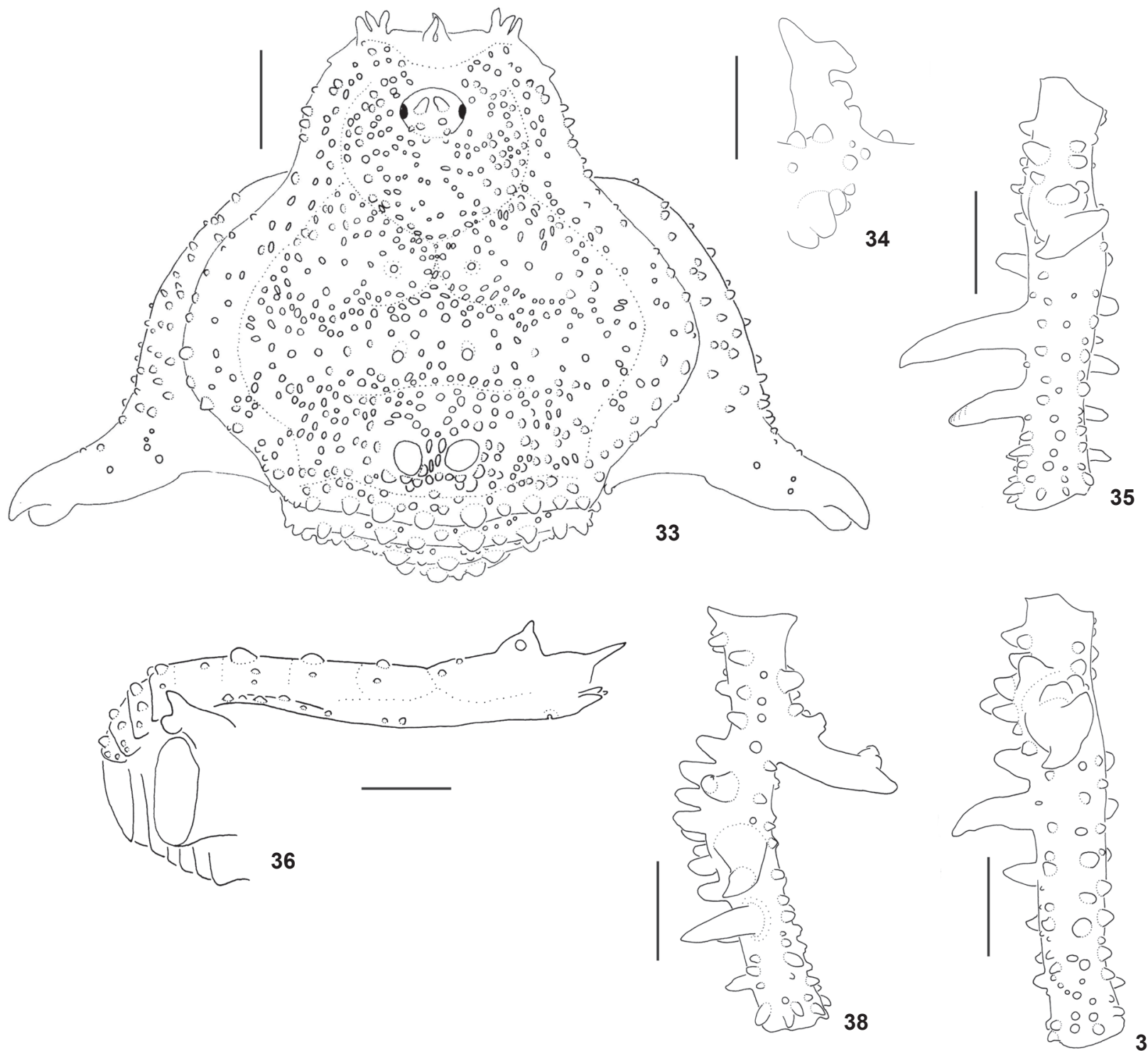

Figures 33-38. Hernandaria una: (33) dorsal habitus, male holotype (MNRJ1468); (34) dorso-basal apophysis of right male femur IV, prolateral view (MNRJ5972); (35) right male femur IV, dorsal view, male holotype (MNRJ1468); (36) body, right lateral view, male (MHNCl6400); (37-38) right male femur IV: (37) dorsal view (MNRJ5972); (38) prolateral view, holotype (MNRJ1468). Scale bar: 1 mm.

External apical apophysis of coxa IV wide, transversal and slightly curved frontwards; short apical branches. Femur IV slightly curved upwards and inwards; retrolateral armature: basal half with five broad spines with half the size of two median, one slightly larger and second slightly curved ventrally, with apical $1 / 3$ having some smaller tubercles; larger tubercles increasing in size apicad in prolateral row, and ventrally with 4-11 (type: 11) very high and blunt tubercles in the median region; dorso-basal apophysis high, length almost the same as diameter of femur, bifid, high and wider until bifurcation, directed slightly back- wards and curved frontwards; internal branch upwards, straight and conical, external branch horizontal, curved downwards, branches similar-sized; two tubercles on anterior face of the base of apophysis. Tarsal formula: 5, 7/9 (7), 6, 6/7 (7). Penis (Figs 138 and 139). Ventral plate with basal setae close to each other in horizontal row, ventralmost much smaller, inserted in a lateral lobe; median seta as ventro-apicalmost setae, at same distance of large dorso-apical. Stylus with oblique apex and without projections; ventral process with losangle flabellum bearing projections on ventral margin. Coloration (Fig. 178). Uniformly 
blackish brown; yellowish pedipalps, metatarsi and tarsi of legs. Measurements. Dorsal scute: 4.0-5.4 (4.9) long; 3.5-5.3 (5.2) wide; legs: I: 7-7.9 (7.4), II: 15.4-17.3 (15.7), III: 11.3-13.2 (12.7), IV: 16.2-18.3, male femur IV: 3.9-4.9 (4.4); pedipalp: 3.5-4.3 (3.5).

Female. It differs from male by having: smaller main pair of tubercles of mesotergal area III, similar sized to those of other areas; conical tubercles on posterior margin and free tergites in some specimens; femur IV with a row of ventro-prolateral larger tubercles, increasing in size apicadly. Measurements. Dorsal scute: 4.2-5.1 long; 3.8-4.7; legs: I: 5.9-7.3, II: 12.6-16.3, III: 9.3-12.4, IV: 13.6-17.5; pedipalp: 3.2-4.

Material examined. Brasil, Paraná: Guaraqueçaba, J.T. Motta, IV.1989, 1 ma (MHNCI6567); Curitiba, A.B. Bonaldo, I.1990, 1 fe (MCN1089); Guaratuba (Usina Hidrelétrica de Guaricana), R. Pinto-da-Rocha, Segalla \& Moura-Leite, without date, $1 \mathrm{ma}$ and 4 fe (MHNCI6400); ibidem, A.B.Kury, R. Pinto-da-Rocha \& A. Giupponi, 08.III.1999, 2 fe (MZSP18132); ibidem, A. Chagas Jr, II.2001, 1 ma and 1 fe (MNRJ4600); ibidem, A.B. Kury, A.P.L. Giupponi \& R. Pinto-da-Rocha, III.1999, 1 ma (MNRJ5818); ibidem, A.B. Kury, A.P.L. Giupponi \& R. Pintoda-Rocha, III.1999, 1 ma and 3 fe (MNRJ5972); São José dos Pinhais, R. Pinto-da-Rocha, III.1992, 2 fe (MZSP16965); Piraquara (Banhado), R. Pinto-da-Rocha, \& A. Chagas, IV.1999, 1 ma (MZSP18668), 1 ma (MZSP18672), 1 ma (MZSP18681); Morretes (P.E. Marumbi), R. Pinto-da-Rocha \& A. Chagas, IV.1999, 4 ma and 1 fe (MZSP18754), 1 ma (MZSP21455); Morretes (Véu da Noiva R. Pinto-da-Rocha \& A. Chagas, IV.1999), 1 ma (MZSP18800); Cruzeiro do Iguaçu (Foz do Chopim), F.S. Oliveira \& A.C. Barros, 14.X.1998, 3 ma and 1 fe (MZSP17888). Santa Catarina: 1 ma and 2 fe (MNRJ1477, syntypes of $M$. heterotypica), without date; Blumenau, 1 ma and 1 fe (MNRJ1468, lectotype ma and paralectotype fe of Proweyhia una, herein designated), without date; Blumenau (Parque Ecológico Spitzkopf), R. Pinto-da-Rocha, R.S. Bérnils \& R. Lingnau, III.1999, 1 ma and 1 fe (MZSP18392); Blumenau (Parque Natural Municipal Nascentes do Garcia), Equipe Biota, I.2003, 20 ma and 19 fe (IBSP5823); Botuverá (near Gruta Botuverá), R. Pinto-da-Rocha, 17-19.I.1998, 1 ma (MZSP 22156).

\section{Hernandaria sundermannorum sp. nov.} Figs $39-42,124,187$

Diagnosis. Closely related to $H$. heloisae, both species differ from other species of the genus by having elongated legs with three larger median spines on male femur IV. It differs from $H$. heloisae by low tubercles on ocularium (instead of one pair of spines united apically), by two pairs of tubercles on mesotergal area IV (instead of one pair), similar density of granules on lateral and anterior sulci of areas (instead of a lower density on lateral sulci), external apical apophysis of male coxa IV straight (instead of curved).

Male description. Dorsum (Figs 39 and 42). Corners of anterior margin of dorsal scute with two apophyses, internal apophysis bifid or trifid at apex. Ocularium with a pair of very low, rounded and convergent tubercles. Mesotergal areas I-IV with more dense granulation near sulci; III with main pair of rounded tubercles on center of area, slightly higher and closer than those of other areas; IV of the same length as area III, with two pairs of tubercles in a central row. Lateral and posterior margins with lower density of granules. Lateral margin with one row of similar-sized tubercles, slightly larger at area II to IV. Posterior margin and free tergites with one row of conical tubercles of similar size as those of lateral margin, some scattered granules. Pedipalps. Tibia IIi ectal and mesal. Tarsus IiI ectal; II mesal. Legs (Figs 40 and 41). All leg tubercles organized in six longitudinal rows pointed backwards, acuminated and similar-sized, in each article, except for femur I and femur IV. Femur I with ventral tubercles twice larger than those on rest of leg I, smaller distad. External apical apophysis of coxa IV oblique, short apical branches. Femur IV long and slightly curved outwards; with three large retrolateral spines on middle, with some small posterior spines until the apex; dorso-basal apophysis high, length more than twice the diameter of femur, bifid; internal branch large, size and width similar to base of apophysis; external branch smaller, short, and horizontal, straight apex; two tubercles on anterior side at base of apophysis. Tarsal formula: 5, 8, 6, 7. Penis (Fig. 124). Ventral plate with long basal setae, close to each other in a horizontal row, inserted in a lateral lobe; median seta small as ventro-apicalmost setae, far from apical setae. Stylus with oblique apex and without projections; ventral process with losangle flabellum bearing projections on ventral margin. Coloration. Uniformly blackish; yellowish pedipalps, metatarsi and tarsi of legs. Measurements. Dorsal scute: 4.4 long; 4.1 wide; legs: I: 7.1 . II: 18.1 , III: 12.2, IV: 17.6, femur IV: 4.8; pedipalp: 3.9.

Female unknown.

Material examined. Brazil, São Paulo: Iporanga (Bombas), Pinto-da-Rocha, R., VI.1994, 1 ma (MNRJ17114, holotype).

Etymology. In honor of Rosa and José Luís Sundermann, a couple of socialist militants from São Paulo state who were killed in 1994 by order of sugar cane landowners because of their fight for rural workers rights.

\section{Hernandaria anitagaribaldiae sp. nov.} Figs 43-47, 113, 122, 123, 179, 186

Diagnosis. Easily recognized from other species of the genus by shape of external apical apophysis of coxa IV. It shares with Hernandaria zumbii sp. nov. an external oblique apophysis of coxa IV and a main pair of conical tubercles on area III. It differs from $H$. zumbii sp. nov. by having same density of granulation near sulci of mesotergal areas I-III.

Male description. Dorsum (Figs 43 and 46). Corners on anterior margin of dorsal scute with two apophyses, internal apophysis bifid at middle, or three similar-sized apophyses (type: 3). Ocularium with one pair of close tubercles, high, rounded apex and curved inwards. Mesotergal areas I-III with more dense granulation near sulci; IV with homogeneous 


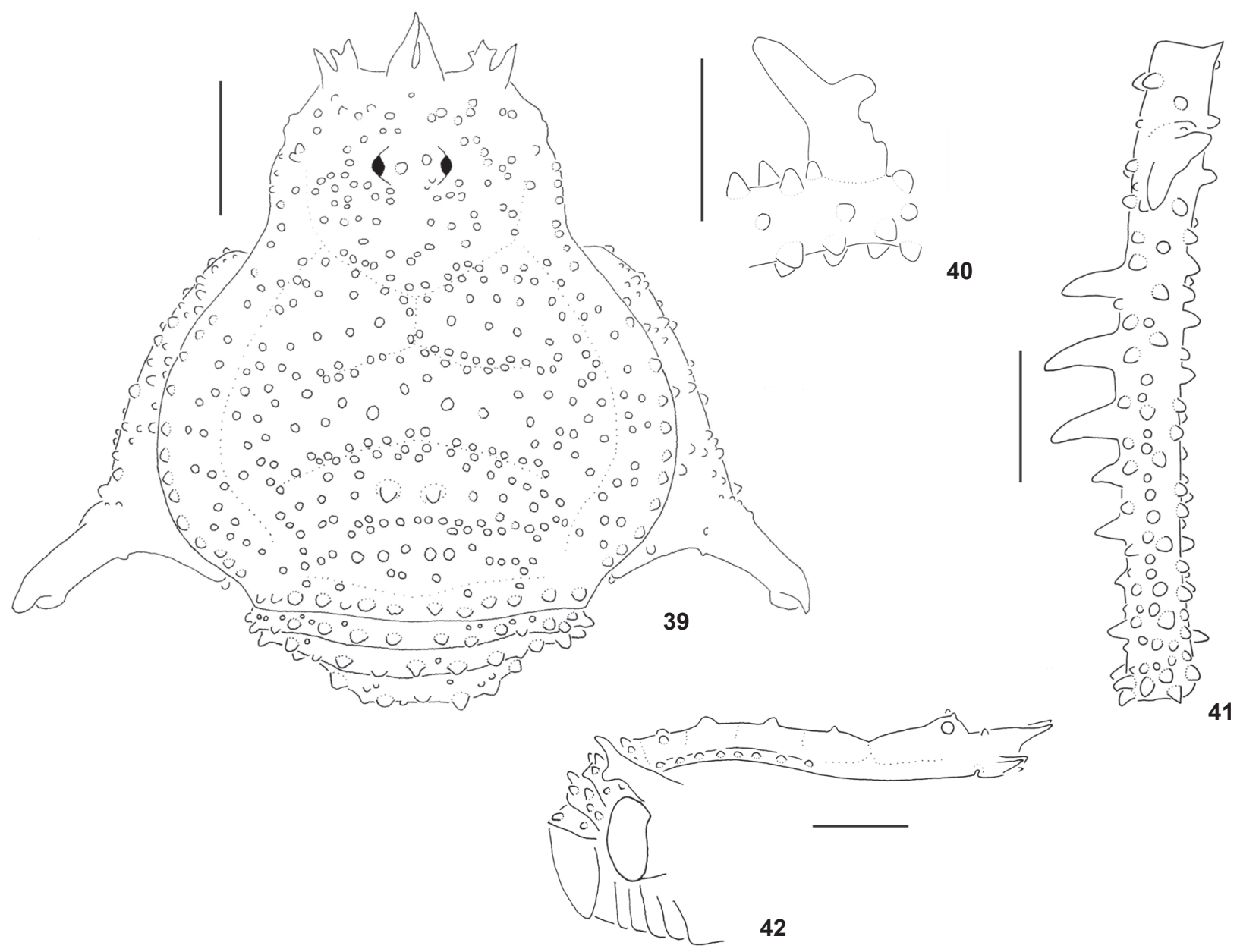

Figures 39-42. Hernandaria sundermannorum sp. nov., holotype (MZSP17114: (39) dorsal habitus; (40) dorso-basal apophysis of right male femur IV, prolateral view; (41) right male femur IV, dorsal view; (42) body, right lateral view. Scale bar: $1 \mathrm{~mm}$.

granulation density; I-III with 1-3 tubercles submedian on each side and one main median pair; I with anterior and lateral longitudinally elongated granules; III with main pair of conical tubercles placed near sulcus IV; IV half size of III, with main pair of tubercles more distant from each other than those of other areas. Lateral and posterior margins with lower density of granules. Lateral margin with one row of scattered tubercles, increasing from area I to main tubercles of area III. Posterior margin and free tergites with a row of larger conical tubercles at middle and some scattered granules. Pedipalps (Fig. 113). Tibia IIi ectal; IIi/II (II) mesal. Tarsus IiI ectal; Ii mesal. Legs (Figs 44, 45 and 47). All leg tubercles organized in six longitudinal rows pointed backwards, similar-sized in each article, except for femur I and IV. Femur I with larger ventral tubercles at basal middle, twice the size of rest on article. External apical apophysis of coxa IV oblique, elongated, slightly shorter than coxa length, thinner at middle and rounded apically; short apical branches. Femur IV curved outwards; retrolateral spines scattered increasing in size until apical 1/4, apical region with smaller tubercles; larger tubercles in two longitudinal rows, one prolateral and the next more ventral, increasing until the apex; high dorso-basal apophysis (length more than twice the diameter of femur), bifid; large internal branch, size and width close to base of apophysis, smaller short horizontal branch with rounded apex; two tubercles at base of apophysis on anterior side. Tarsal formula: 5, 7/8 (7), 6, 7. Penis (Figs 122 and 123). Ventral plate with basal setae close to each other in horizontal row, two ventralmost much smaller, inserted in a large lateral lobe; median seta twice as large as ventro-apical setae, at same distance of large dorsoapical setae. Stylus with straight apex and without projections; ventral process with losangle flabellum bearing projections on ventral margin. Coloration (Fig. 179). Uniformly blackish, with yellowish pedipalps, chelicerae, metatarsi and tarsi 


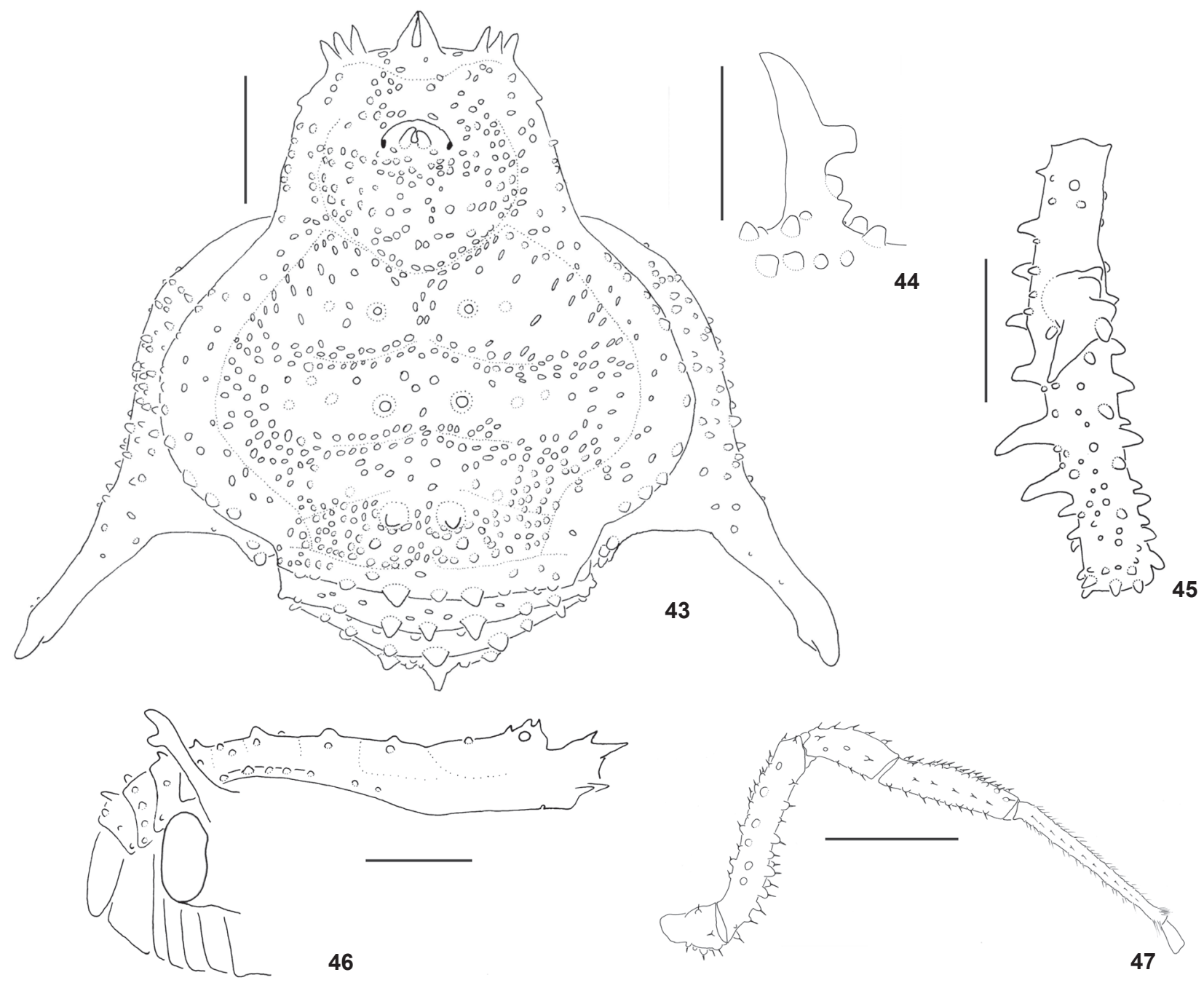

Figures 43-47. Hernandaria anitagaribaldiae sp. nov.: (43) dorsal habitus, male holotype (MZSP18326); (44) dorso-basal apophysis of right male femur IV, prolateral view (MZSP18331); (45) right male femur IV, dorsal view (MNRJ6953); (46) body, right lateral view (IBSP5854); (47) trochanter-tarsus I (MZSP18660). Scale bar: $1 \mathrm{~mm}$.

of legs. Measurements. Dorsal scute: 3.3-4.3 (4) long; 3-4.2 (4.2) wide; legs: I: 5.6-6.6 (6.6), II: 11.4-14.1 (14.1), III: $7.7-$ 10.4 (10.4), IV: 11.8-14.7 (13.4), male femur IV: 2.7-3.9 (3.6); pedipalp: 3.1-3.8 (3.6).

Females. It differs from male by having: smaller main pair of tubercles of area III, of size similar to other areas; femur IV with a row of larger ventro-prolateral tubercles and increasing apicad. Measurements. Dorsal scute: 3-4.3 long; 3.1-3.9 wide; legs: I: 4.9-6.9, II: 10.7-11.5, III: 7.8-9.1, IV: 10.9-12.6; pedipalp: 2.7-3.9.

Material examined. BRAsil, Santa Catarina: Balneário Camboriú (Praia da Laranjeira), A. P. L. Giupponi, II.2002, 1 fe (MNRJ4959, paratype); Ilhota (Parque Botânico Morro do
Baú), A. Bonaldo, A. B. Kury \& R. Pinto-da-Rocha, II.1996, 1 ma (MNRJ6953, paratype); ibidem, R. Pinto-da-Rocha, R. Bérnils \& R. Lingnau, IV.1999, 1 ma and 1 fe (MZSP29092, paratype); Blumenau (Parque Ecológico Spitzkopf), R. Pintoda-Rocha, R. Bérnils \& R. Lingnau, III.1999, 1 ma and 1 fe (MZSP18331, paratype); ibidem, R. Pinto-da-Rocha, R. Bérnils \& R. Lingnau, III.1999, 1 ma (IBSP, holotype); ibidem, 1 ma (MZSP18326, paratype); (Parque Natural Municipal Nascentes do Garcia), Equipe Biota, I.2003, 4 ma (IBSP5854, paratype). Etymology. In honor of Anita Garibaldi (1821-1849), republican revolutionary from Santa Catarina state who fought for freedom against the monarchal central government of Brazil and in Europe. 


\section{Hernandaria zumbii sp. nov. \\ Figs 48-51, 140, 141, 187}

Diagnosis. Closely related to $H$. anitagaribaldiae sp. nov. by having an oblique external apophysis of coxa IV and a conical main pair of tubercles of area III. This is the only species of Hernandaria with a smaller density of granules on area I than other areas and a swollen basitarsus I. Femur IV differs by large subapical spine. External apical apophysis of coxa IV shape is unique.

Male description. Dorsum (Figs 48 and 51). Corners on anterior margin of dorsal scute with three similar apophyses. Anterior margin smooth. Ocularium with one pair of close tubercles, with rounded apex and curved inwards. Mesotergal areas I-II with denser granulation near sulci; III-IV with homogeneous granulation density; I with a smooth center; anterior and lateral granules elongated longitudinally; main pair of tubercles of area II low and conic, with one pair of rounded smaller paramedian tubercles; III with main pair of conical tubercles pointed backwards and close to area IV; IV half size of III and almost unnoticed, except for main pair of tubercles, more distant than from other areas. Lateral and posterior margins with lower density of granules. Lateral margin with one row of similar-sized tubercles from area I to IV. Posterior margin and free tergites with one row of conical larger tubercles on median portion and tergites II-III. Pedipalps. Tibia IIi ectal; II mesal. Tarsus IiI ectal; II mesal. Legs (Figs 49 and 50). Femur I with larger ventral tubercles at basal middle, slightly larger than tubercles on the rest of article. Tibiae I-II with similar-sized tubercles in six longitudinal rows pointed backwards. Basitarsus I swollen. External apical apophysis of coxa IV oblique, long, thin apicadly; dorsal branch long and longitudinal, ventral branch very reduced. Femur IV short, straight, thinner at base; retrolateral spines increasing in size until basal half, plus one similar-sized apical spine, curved backwards, and one subapical, twice the size of others; small prolateral spines increasing in size from the middle to apex; high dorso-basal apophysis, more than twice the diameter of femur, bifid; posteriorly close to this is a dorso-basal spine similar-sized to retrolateral; internal branch acuminate, larger than base of apophysis, and smaller branch short, horizontal and curved downwards. Tarsal formula: 5, 7, 6, 7. Penis (Figs 140 and 141). Ventral plate with deep subapical concavity; with basal setae close to each other in horizontal row, ventralmost much smaller, inserted in a large lateral lobe; median seta similar-sized to ventroapicalmost setae, far from dorsal-apical setae. Stylus with straight apex and small subapical ventral projections; ventral process with losangle flabellum bearing projections on ventral margin and a median pointed axis. Coloration. Light brown, pedipalps yellowish, dorso-basal apophysis and larger spine of femur IV, external apophysis of coxa IV, main pair of tubercles of area III, and ocularium blackish. Measurements. Dorsal scute: 4.0 long; 4.1 wide; legs: I: 6.4, II: 13.3, III: 9.9, IV: 14.2, femur IV: 3.9; pedipalp: 3.3 .
Female unknown.

Material examined. BRasil. Santa Catarina: Ilhota (Parque Botânico Morro do Baú), R. Pinto-da-Rocha, R. Bérnils \& R. Lingnau, IV.1999, 1 ma (MZSP18660, holotype).

Etymology. In honor of Zumbi dos Palmares (1655-1695), leader of the Quilombo dos Palmares, town where black slaves lived after escaping from Portuguese landlords in northeast Brazil. He is a symbol of black resistance in Brazil.

\section{Hernandaria chicomendesi sp. nov.} Figs $52-56,120,121,186$

Diagnosis. It is similar to $H$. setulosa by having short legs with high tubercles, main pair on mesotergal area III are large, and IV is very narrow. Ocularium tubercles similar to those of H. una. It is easily recognized by the falcate external apical apophyses of coxa IV and short falcate dorso-basal apophysis of femur IV.

Male description. Dorsum (Figs 52 and 56). Corners on anterior margin with two apophyses (internal apophysis trifid); median pair of larger apophyses and remaining area on anterior margin with small spines; region behind these apophyses almost of same height as ocularium. Prosoma densely granulated, more than opistosoma. Ocularium with one pair of close and weak tubercles, with rounded apex and curved inwards, jointed at apex. Mesotergal areas I-III with granulation more dense near sulci, except lateral region; IV with granulation density almost uniform; I-IV with 1-3 submedian tubercles in each side, beside main median pair; III with main pair of rounded tubercles, larger than other tubercles, flattened and placed posteriorly; IV very narrow, with two pairs of tubercles on each side (type: one central absent). Lateral margin with lower density of granules, except on area III. Lateral margin with one row of similar sized tubercles from area I to III. Posterior margin and free tergites with one row of similar sized rounded tubercles per segment, larger on posterior margin than on free tergites. Pedipalps. Tibia IIi ectal and mesal. Tarsus II ectal and mesal. Legs (Figs 53-56). All leg tubercles organized in six longitudinal rows pointed backwards, high and with rounded apex and similar-sized, in each article, except for femur I and IV. Femur I with slightly larger ventral tubercles, irregularly distributed. External apical apophysis of coxa IV short, transversal, large base; apex falcate, with anterior branch more than twice as large as posterior. Femur IV short, thinner until dorso-basal apophysis; five spines increasing in size until posterior half of article, apical twice larger than anterior; larger tubercles increasing apicadly in prolateral row, concentrated on dorso-apical region, smaller and less dense ventrally; dorsobasal apophysis with short base, bifid, apex falcate; internal branch larger than external; some large tubercles anterior to apophysis. Tarsal formula: 4, 7, 6, 6. Penis (Figs 120 and 121). Shallow apical concavity of ventral plate. Ventral plate with basal setae close to each other in oblique row, almost vertical, except for smaller ventral seta; median seta as small as ventro- 


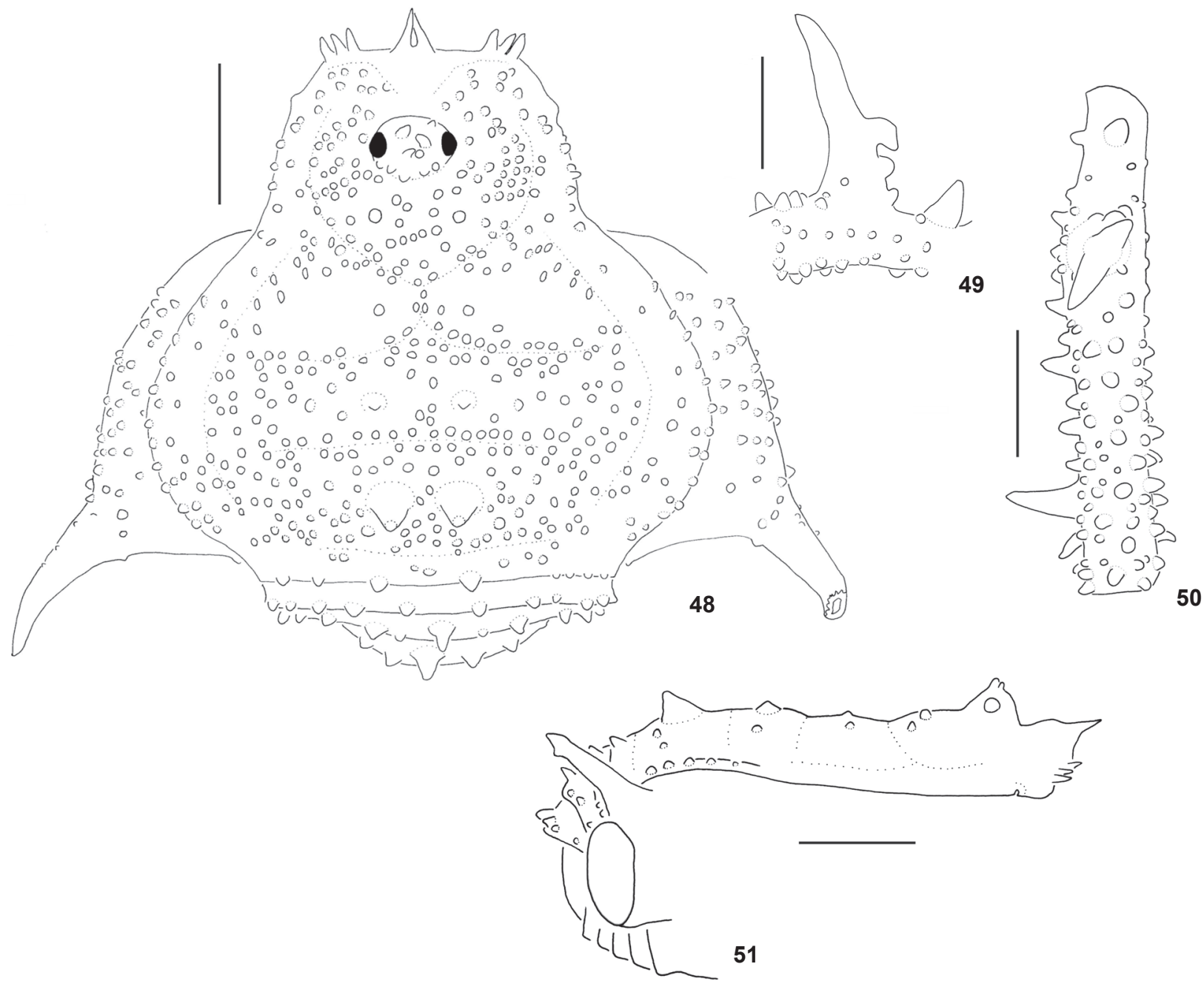

Figures 48-51. Hernandaria zumbii sp. nov., male holotype (MNRJ18660): (48) dorsal habitus; (49) dorso-basal apophysis of right male femur IV, prolateral view; (50) right male femur IV, dorsal view; (51) body, right lateral view. Scale bar: $1 \mathrm{~mm}$.

apical setae. Stylus with oblique apex and without projections; ventral process with flabellum bearing projections on ventral margin. Coloration. Lost in ethanol. Light brown with apex of apophyses brown. Measurements. Dorsal scute: 3.6; width: 3.7 wide; legs: I: 5.1, II: 10.5, III: 8. IV: 12.6, male femur IV: 3.1; pedipalp: 2.5 .

Female unknown.

Material examined. BrasiL, Santa Catarina: Florianópolis (Ilha de Santa Catarina, forest behind buildings of APAE, ÚNICA and SESI), A. Giupponi, \& D. Pedroso, XII.1999, 1 ma (MNRJ14313, holotype).

Etymology. In honor of Chico Mendes (1944-1988), rubber extraction union leader who fought for Amazon preservation and against worker exploitation. He was killed by landlords as a reaction to his fight for the Amazon.

\section{Acrogonyleptes Roewer, 1917}

Acrogonyleptes Roewer, 1917: 136 [desc]; 1923: 507 [redesc], 1930: 390 [key]; Mello-Leitão, 1926: 353 [key]; 1931a: 134 [syst]; 1932: 317 [redesc, key]; 1935: 104 [key]; Soares \& Soares, 1949: 157 [cat, redec, key]; 1984, 305 [redesc, key]; Kury, 2003: 140 [cat].

Sphaerobunus Roewer, 1917: 142 [desc]; 1923: 536 [redesc]; MelloLeitão, 1932: 359 [redesc]; Soares \& Soares, 1948: 580 [cat]; 1985a: 179 [redesc]; Kury, 2003: 139 [cat]. (type species = Sphaerobunus rhinoceros Roewer, 1917 by monotypy). Syn. nov. Acrogonyleptoides Mello-Leitão, 1931a: 134 [desc]; 1935: 104 [key]; Soares \& Soares, 1946: 105 [syst]; 1949: 157 [cat, redec, key]; 1984: 305 (syn. Acrogonyleptes Roewer, 1917) [syst]. (type species $=$ Acrogonyleptoides exochus Mello-Leitão, 1931, by original designation). 


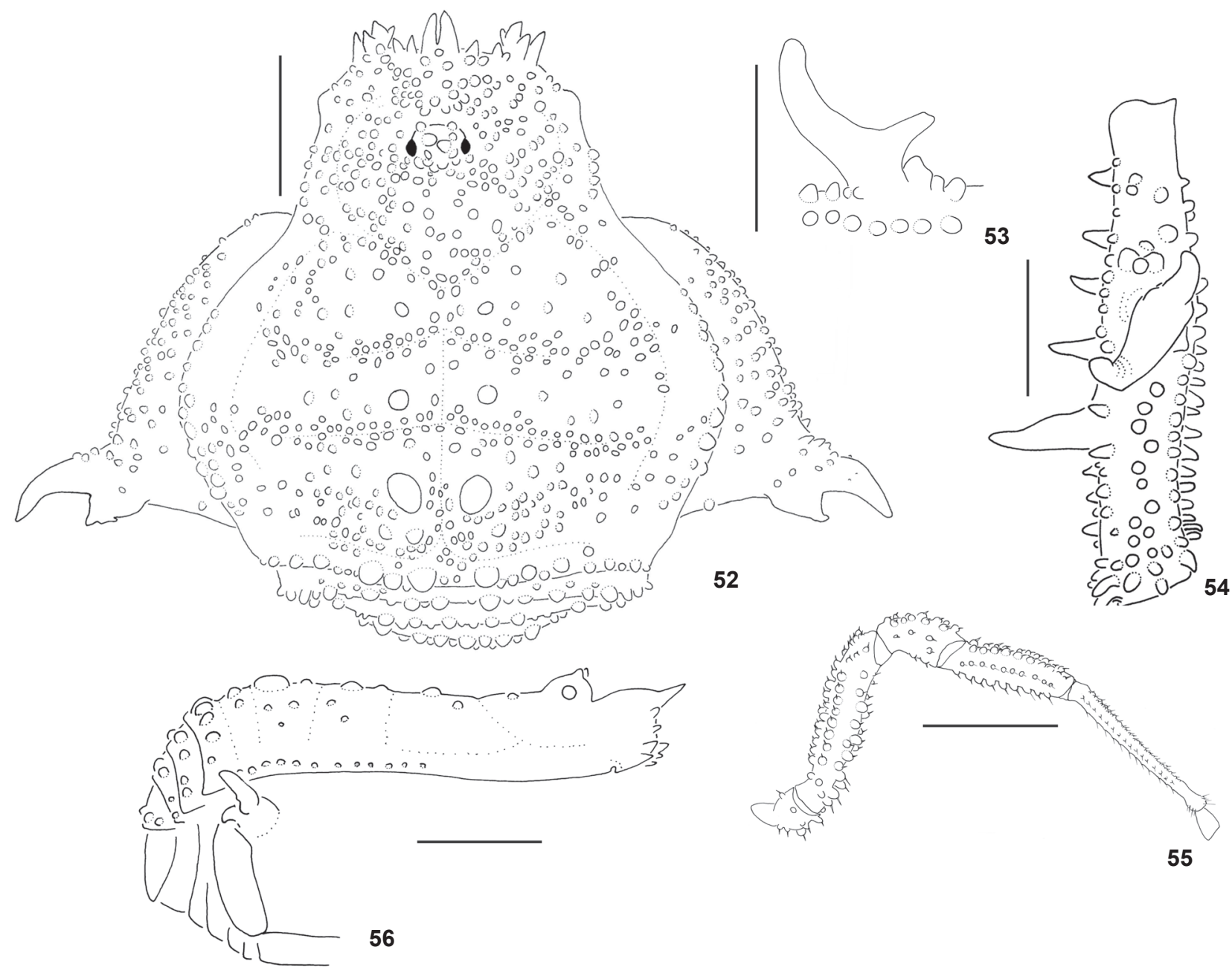

Figures 52-56. Hernandaria chicomendesi sp. nov., male holotype (MNRJ14313): (52) dorsal habitus; (53) dorso-basal apophysis of right male femur IV, prolateral view; (54) right male femur IV, dorsal view; (55) body, right lateral view; (56) trochanter-tarsus of right leg I, retrolateral view. Scale bar: $1 \mathrm{~mm}$.

Melloleitaniana B. Soares, 1943: 207 [desc]; H. Soares, 1945: 215 [syst]; Soares \& Soares, 1947b: 254 [syst]; Soares \& Soares, 1949: 190 [cat, redec, key]; 1984, 305 (syn. Acrogonyleptes) [syst]; H. Soares, 1966a: 88 [redesc]; Tavares, 1980: 157 [redesc]. (type species = Melloleitaniana curitibae Soares \& Soares, 1943, by original designation).

Paraproweyhia Soares \& Soares, 1947a: 138 [desc]; 1949: 207 [cat, redec, key]; 1984: 303 (syn. Hernandaria) [syst]. (type species $=$ Paraproweyhia curitibae Soares \& Soares, 1947, by original designation). Syn. nov.

Pseudoacrogonyleptoides H. Soares, 1966a: 89 [desc]; Soares \& Soares, 1984: 305 (syn. Acrogonyleptes) [syst]. (type species = Pseudoacrogonyleptoides granulatus H. Soares, 1966).

Type species: Acrogonyleptes spinifrons Roewer, 1917, by monotypy.
Diagnosis. Sexual dimorphism: male leg IV, posterior margin and free tergites of female armed (except $A$. granulatus) and lateral margin of female mesotergum armed (except $A$. cheguevarai sp. nov.). Convergent pair of median apophyses on anterior margin of prosoma, touching at apex, larger than those of angles. Prosoma entirely covered by granules, with lower density at middle, behind ocularium, and on anterior and lateral margins. Ocularium with one pair of inwardly curved convergent tubercles or parallel and straight tubercles or spines (except $A$. exochus, with a single spine). Three mesotergal areas on dorsal scute. Main pair of tubercles of area III fused. Areas I-III with tubercles of several sizes on each side; I with anterior and lateral granules elongated longitudinally. Lateral margin with few tubercles, larger at wider region of mesotergum. Posterior margin and free tergite I with some tubercles or larger spines; II-III with one tubercle 
or larger median spine. Coxa IV (except externally apical male apophysis), stigmatic and genital areas uniformly covered by granules. Pedipalp femur thinner than or of similar diameter as other articles. Legs with small similar-sized tubercles, except femur IV. Tarsus I with five articles. Penis with ventral plate longer than wide, with narrow apical concavity and U-shaped. Basal setae of ventral plate inserted in horizontal row on lateral lobe longer than wide, ventralmost seta smaller.

\section{Key to species of Acrogonyleptes}

1. Pedipalpal femur thinner than other articles, tarsus biconvex (Fig. 114); one tubercle or larger spine on lateral margin of dorsal scute (Figs 57, 62 and 85) 2

1 '. Pedipalpal femur with same diameter than other articles, tarsus ventrally straight (Figs 112 and 113); two or more larger tubercles (Figs 71 and 74), gradually larger tubercles (Fig. 70) or tubercles of similar size (Fig. 88) on lateral margin of dorsal scute

4

2. Ocularium tubercles a bit far from each other; single main tubercle on area III; external apophysis of male coxa IV almost transversal (Figs 82-87) A. rhinoceros

2 '. Ocularium tubercles convergent (touching apically) or single (Figs 57 and 62); main pair of tubercles of area III fused, with apexes free and rounded (Figs 57, 62 and 66); oblique external apophysis of male coxa IV (about $45^{\circ}$ regarding longitudinal axis) (Figs 57 and 62) .. 3

3. Single spine on ocularium; free tergites II-III with one median spine and some smaller similar-sized tubercles (Figs 57-61)

A. exochus

3'. Pair of tubercles on ocularium convergent (touching apically); free tergites II-III with three larger spines (median largest) (Figs 62-66) ..... A. granulatus

4. Three or more median tubercles fused (males/females) or very close (only females) on area III; small spines on anterior region of ocularium and behind median apophysis on anterior margin of prosoma; male with one dorso-apical apophysis with same size as basal one on femur IV (Figs 8891) ................................................ A. cheguevarai sp. nov.

4 '. One pair of tubercles fused (males/females) or very close (only females) on area III (Figs 67 and 71); only granules between ocularium and median apophyses on anterior margin (Figs 67 and 71); male femur IV without dorso-apical apophysis (Figs 69-73)

... 5

5. Male: External apophysis of coxa IV with backwards apex; dorso-basal apophysis high with two short branches. Female: Femur IV with prolateral row of larger spines (Figs 67-70) A. pectinifemur

5'. Male: External apophysis of coxa IV with short branches; dorso-basal apophysis low with two branches of similar size as its base. Female: Femur IV with larger retrolateral and prolateral spines (Figs 71-81).... A. spinifrons

\section{Acrogonyleptes exochus (Mello-Leitão, 1931)}

Figs 57-61, 142, 143, 180, 181, 186

Acrogonyleptoides exochus Mello-Leitão, 1931a: 134 (fig. 7) [desc]; 1935: 106 [cit]; B. Soares, 1945a: 194 [cit]; 1945b: 353 [cit]; Soares \& Soares, 1946: 105 [syst]; 1949: 158 [cat]; Pinto-daRocha \& Caron 1989: 1023 [cit].

Acrogonyleptes exochus Soares \& Soares, 1984: 306 (figs 15-16) [redesc]; Kury, 2003: 141 [cat].

Acrogonyleptoides piraquarensis Soares \& Soares, 1946: 103 (fig. 2) [desc]; 1949: 158 [cat]; 1984: 306 (syn. Acrogonyleptes exochus) [syst]; Pinto-da-Rocha \& Caron 1989: 1023 [cit].

Paraproweyhia curitibae Soares \& Soares, 1947a: 139 (fig. 1) [desc]; 1949: 207 [cat]; 1984: 303 (syn. Hernandaria heloisae (H. Soares, 1945)) [syst]. syn.n.

Diagnosis. A. exochus is closely related to A. granulatus and $A$. rhinoceros by having a thinner pedipalpal femur than remaining articles and by biconvex tarsus, two single apophyses on corners of anterior margin of dorsal scute and by one tubercle on lateral margin of dorsal scute being larger than others. A. exochus differs from other species of genus by having a single spine on ocularium and by stronger dark pigmentation on mesotergal area III, contrasting with rest of body and reticulated pigmentation on other areas.

Male redescription. Dorsum (Figs 57 and 61). Two single apophyses on corners of anterior margin of dorsal scute. Ocularium with a single median spine. Mesotergal area III with main pair of tubercles fused, apexes rounded and free. Lateral margin of dorsal scute with one row of similar-sized tubercles with one larger, eventually longer than wide (type: long) on wider region of mesotergum, might have one or two additional slightly smaller closer tubercles (type: 1/0). Posterior margin of dorsal scute and free tergites with similar-sized rounded tubercles; posterior margin and free tergite I unarmed, free tergites II-III with one large median spine (type: III larger). Pedipalps. Femur and trochanter elongated, diameter narrower than tibia and tarsus. Tarsus biconvex. Tibia IIi/IiIi (type: IIi) ectal; II/IIi/Iili mesal. Tarsus II ectal and mesal. Legs (Figs 58-60). External apical apophysis of coxa IV oblique, large, with wider apex, bifid; dorsal branch acuminated and ventral branch rounded, both similar-sized; internal apical apophysis large and pointed, of similar size as median spines on free tergites. Femur IV slightly curved inwards with 2-5 (type: 3) spines on basal 1/3, one larger submedian apical spine, and 1-2 (type: 2) apical spines, similar-sized to basal, pointed backwards; row of prolateral spines increasing apicad, apicalmost curved backwards. Dorso-basal apophysis larger than diameter of femur, bifid, with internal branch acuminated and larger than base, external short and curved downwards, rounded apex. Tarsal formula: 5, 7/10 (10), 6/7 (8), 7/9. Penis (Figs 142 and 143). Ventral plate with apical concavity shallow and narrow, Ushaped; large lateral lobe, longer than wide; median seta as small as ventro-apical setae, at same distance from dorsal and 


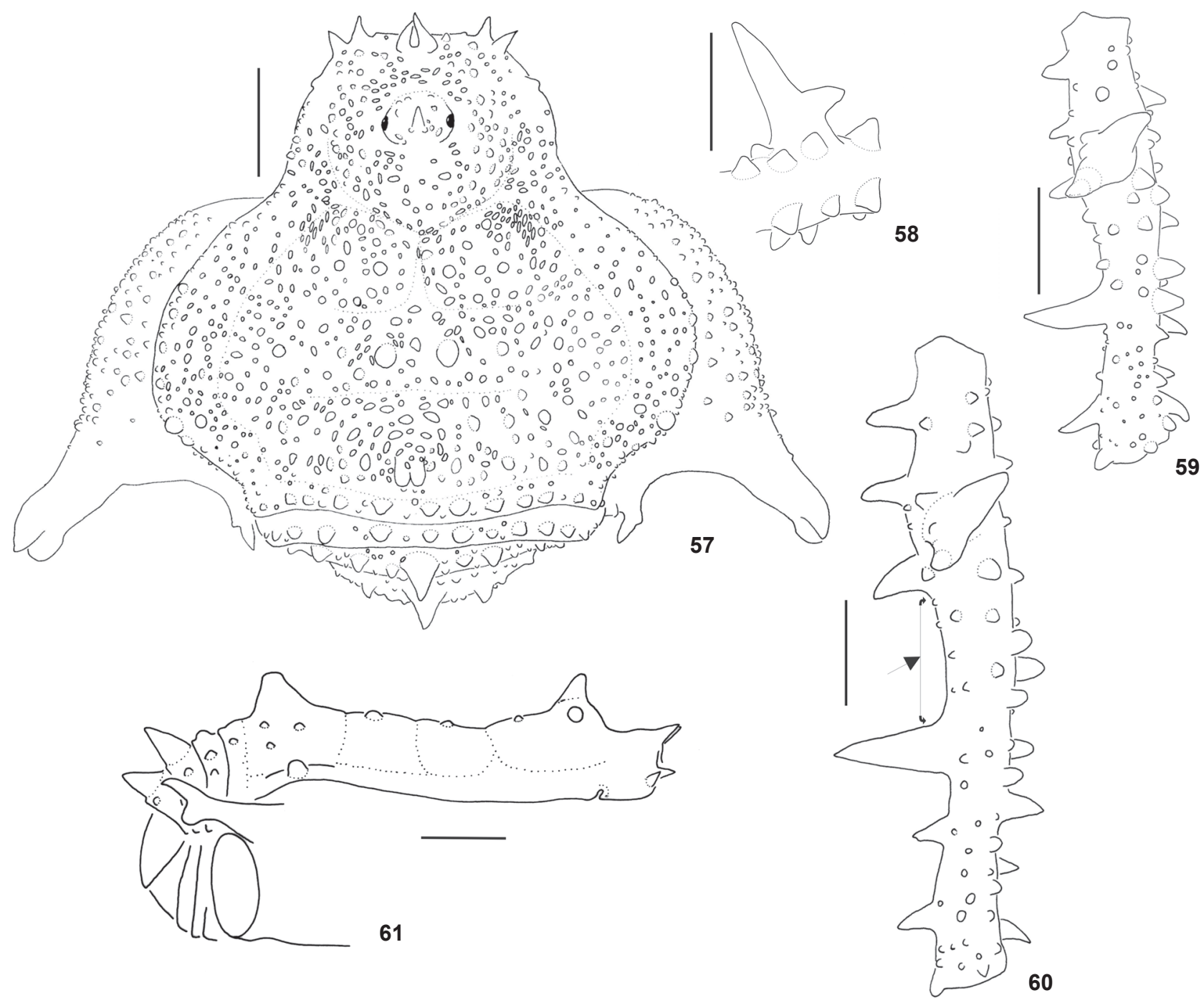

Figures 57-61. Acrogonyleptes exochus: (57) dorsal habitus (MZSP18669); (58) dorso-basal apophysis of right male femur IV, prolateral view (MHNCI6401); (59-60) right male femur IV, dorsal view; character 61 showed with arrow (MZSP18679 and MCN1277, respectively); (61) body, right lateral view (MCN1277). Scale bar: $1 \mathrm{~mm}$.

ventral setae. Ventral process with flabellum bearing projections on ventral margin. Glans stylus with oblique apex and with ventro-subapical projections. Coloration (Figs 180 and 181). Light brown, yellowish pedipalps, metatarsi and tarsi of legs, leg IV blackish. Dark reticulate pigmentation, denser on area III becoming darker or black. Measurements. Dorsal scute: 4.4-5.6 (5.6) long; 5.1-6.4 (6.4) wide; legs: I: 6.7-8.8 (8.8), II: 15.5-21 (21), III: 11.5-15.9 (15.9), IV: 15.9-20.5, male femur IV: 4.1-6.2 (6.2); pedipalp: 4-5 (4).

Female (Fig. 181). It differs from male by having: larger main spines of posterior margin and free tergites, eventually with one smaller spine on free tergite I; lateral margin of dorsal scute with larger and conical main tubercle; femur IV with row of spines scattered at median basal retrolateral region and with a dorsal prolateral row. Measurements. Dorsal scute: 4.1-5.7 long; 4.4-5.9; legs: I: 6.8-8.3, II: 15-22, III: 10.9-14.7, IV: 15.120.3; pedipalp: 4-5.

Material examined. Brasil, Paraná: Rio Negro, T. Borgmeyer, without date, 1 ma (MNRJ11391, holotype of A. exochus); Guaratuba (Serra da Prata), Gengnagel, X.1947, 1 ma (HSCP207); Curitiba, Gengnagel, XII.1950, 1 ma (HSCP208); ibidem, Gengnagel, XII.1948, 1 fe (HSCP209); Balsa Nova (Serra de São Luiz), R. Pinto-da-Rocha, A. B. Kury \& A. P. L. Giuponni, III.1999, 2 ma and 1 fe (MZSP18141); Rio Jacutinga, I. Knysak, IV.1980, 4 
fe (IBSP745); Quatro Barras (Alto da Serra), R. Pinto-da-Rocha, XI.1987, 2 ma and 1 fe (MHNCI6401); Quatro Barras, R. Pinto da Rocha, XI.1988, 1 ma and 1 fe (MHNCI6302); Campina Grande do Sul (Faz. Capivari), V. G. Persson, without date, 1 fe and 2 i (MHNCI6792); Piraquara, R. Pinto-da-Rocha \& A. Chagas, IV.1999, 1 ma and 2 fe (MZSP18669); Piraquara (Banhado), G. Hatschbach, VII.1945, 1 ma (MHNCI3624, holotype of $A$. piraquarensis); ibidem, R. Pinto-da-Rocha \& A. Chagas, IV.1999, 1 ma and 2 fe (MZSP18679); ibidem, R. Pinto-da-Rocha \& R.S. Bérnils, I.1991, 2 ma and 2 fe (MHNCI6844). Santa Catarina: Rancho Queimado, A.B. Bonaldo, X.1994, 2 ma and 2 fe (MCN1253); ibidem, A.B. Bonaldo, I.1995, 3 ma and 5 fe (MCN1277); ibidem, A.B. Bonaldo, XI.1995, 3 fe (MCN1293). Rio Grande do Sul: Caxias do Sul (Vila Oliva), A. Lise, IV.1975, 1 ma (MCN450); without date, 1 ma (MHNCI34).

\section{Acrogonyleptes granulatus (H. Soares, 1966), revalid. comb. nov. \\ Figs 62-66, 114, 146-148, 185}

Pseudoacrogonyleptoides granulatus H. Soares, 1966a: 89 [desc]; Soares \& Soares, 1984: 306 (figs 15-16) (syn. Acrogonyleptes exochus Mello-Leitão, 1931) [syst].

Diagnosis. A. granulatus closely related to A. exochus and $A$. rhinoceros by having a thinner pedipalpal femur than remaining articles along with a biconvex tarsus, with two single apophyses on corners of anterior margin of dorsal scute and by one tubercle on lateral margin of dorsal scute larger than other. It has low and convergent tubercles, as A. cheguevarai sp. nov., but differs from other genus species by having three strong spines on free tergites II-III.

Male description. Dorsum (Figs 62 and 65). Two single apophyses on corners of anterior margin of dorsal scute. Ocularium with one pair of small tubercles, curved inwards, with rounded apex. Mesotergal area III with main pair of tubercles fused, apexes free and rounded. Lateral margin of dorsal scute with one row of similar-sized tubercles and one larger on wider region of mesotergum, longer than wide. Posterior margin of dorsal scute and free tergites with rounded similarsized tubercles; posterior margin unarmed, free tergite I with one large conical tubercle; free tergites II-III with one large median spine, III largest, and one pair of paramedian smaller spines. Pedipalps (Fig. 114). Femur and trochanter elongated, diameter narrower than tibia and tarsus. Tarsus biconvex. Tibia IIi ectal and mesal. Tarsus II ectal and mesal. Legs (Figs 63 and 64). External apical apophysis of coxa IV oblique, elongated, with wider apex, bifid; dorsal branch acuminated, larger, ventral rounded; large and pointed internal apical apophysis, size similar to central spines of free tergites. Femur IV slightly curved inwards with 3-4 spines on basal 1/3, one larger submedian apical spine, 2-3 apical spines, similar-sized to basal, pointed backwards; row of prolateral spines, increasing apicad, apicalmost curved backwards; some of smaller spines with truncated apex. Dorso-basal apophysis larger than the diameter of femur, bifid, with internal branch acuminate and larger than base, external small and curved downwards, rounded apex. Tarsal formula: 5, 8/11 (8/9), 6/7 (6/7), 7/9 (7). Penis (Figs 146-148). Ventral plate with apical concavity swallow and narrow, V-shaped; lateral basal lobe as long as wide; short dorso-apical setae; median seta slightly larger than those more ventro-apical, inserted at same vertical line of dorso-apical. Ventral process with flabellum bearing projections on ventral margin and long longitudinal axis. Glans stylus with oblique apex and with small ventral subapical projections. Coloration. Light brown, legs lighter and yellowish pedipalps. Measurements. Dorsal scute: 3.7-4.2 long; 3.7-4.7 wide; legs: I: 6.5-7.2, II: 15-17.3, III: 10-11.5, IV: 13.8-15.8; male femur IV: 3.7-4.2; pedipalp: 4-4.9.

Female. It differs from male by having: femur IV with row of spines scattered at middle basal retrolateral and dorsal region; one prolateral row of spines in all extension. Measurements. Dorsal scute: 3.8-4.6 (3.8) long; 3.6-4.3 (4.2) wide; legs: I: 6.1-8.2 (6.1), II: 14.3-19.6 (15), III: 9.6-14.2 (9.6), IV: 12.4-18.4 (12.4), male femur IV: 3.7-4.2; pedipalp: 3.4-4.9 (3.4). Material examined. Brasil, Paraná: Piraquara (Banhado), Gofferjé, 1947, fe (CGPC917, holotype of Pseudoacrogonyleptoides granulatus). Santa Catarina: Rancho Queimado, L.Moura, X.1995, 1 fe (MCN1297). Rio Grande do Sul: Cambará do Sul, A.B. Bonaldo, XI.1993, 1 fe (MCN1204); Caxias do Sul (Vila Oliva), A. Lise, I.1976, 1 ma (MCN447); Caxias do Sul (Vila Oliva), A. Lise, IV.1975, 1 ma (MCN450); São Francisco de Paula, without collector, III.1988, 7 ma, 7 fe e 4 i (MCN1352); São Francisco de Paula (Potreiro Velho), A. Lise, III.1997, 17 ma and 7 fe (MCP186); ibidem, A. Lise, III.1997, 2 ma and 2 fe (MCP226); ibidem, A. Lise, V.1997, 2 ma and 1 fe (MCP228); ibidem, A. Lise, VI.1997, 4 fe (MCP229); ibidem, A. Lise, II.1998, 3 ma and 3 fe (MCP231).

\section{Acrogonyleptes pectinifemur (Soares \& Soares, 1947) comb. nov. \\ Figs 67-70, 149-151, 187}

Melloleitaniana pectinifemur Soares \& Soares, 1947b: 251, 253, figs 2-3 [desc]; 1949: 191 [cat]; H. Soares, 1966a: 89 [cit]; H. Soares, 1966b: 118 [cit]; Soares \& Soares, 1984: 306 (syn. A. curitibae (B. Soares, 1943) [syst].

Diagnosis. Acrogonyleptes pectinifemur is similar to $A$. spinifrons, both differ from other species of the genus by large body size and divergent pair of spines on ocularium. It differs from $A$. spinifrons by external apophysis of male coxa IV with long and backward directed apex; by high dorso-basal apophysis of male femur IV and by higher, comb-like armature on retrolateral and prolateral of male (only prolateral in female) femur IV.

Male redescription. Dorsum (Figs 67 and 70). Corners of anterior margin of dorsal scute with two single apophyses or 


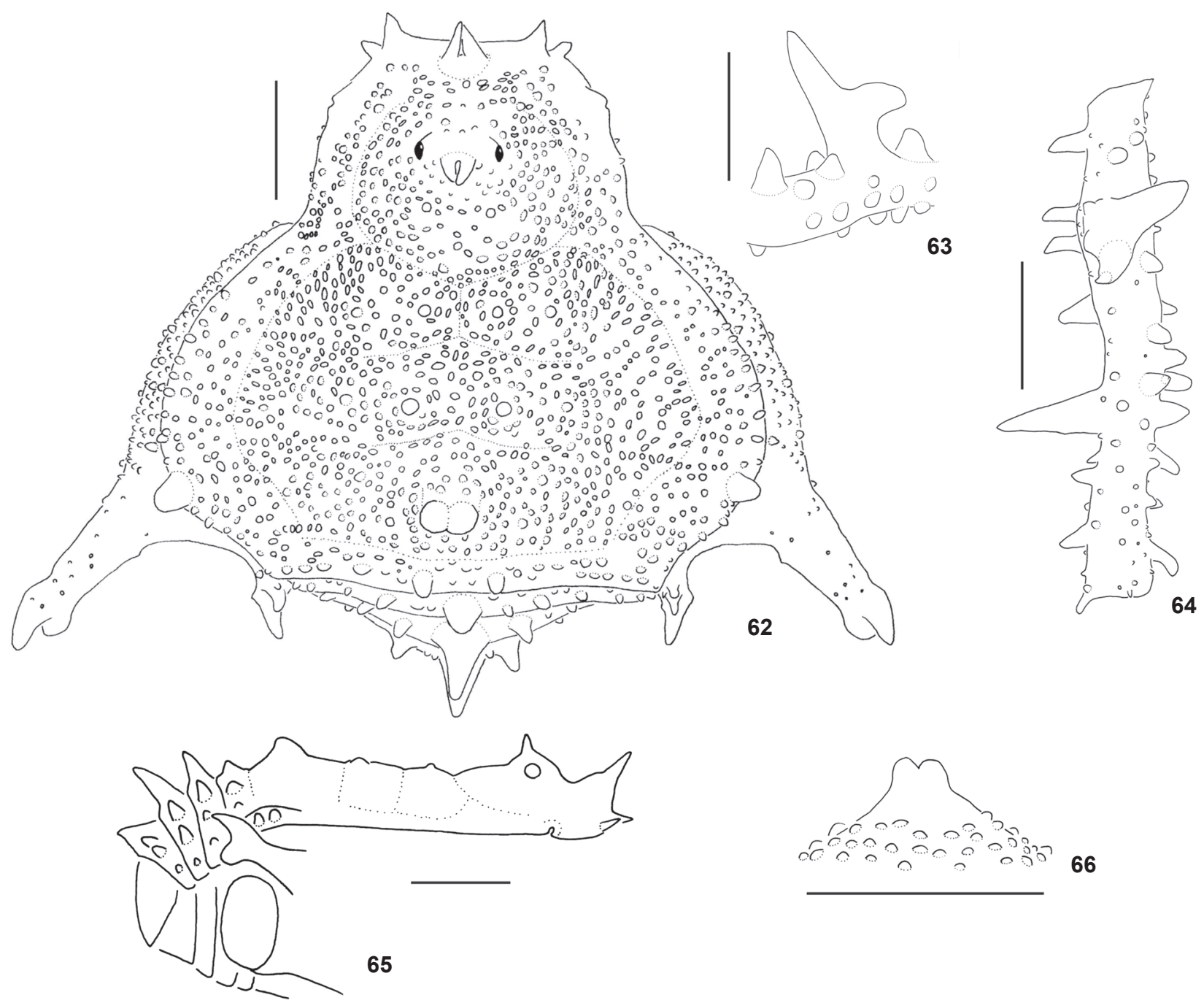

Figures 62-66. Acrogonyleptes granulatus (MCP186): (62) dorsal habitus; (63) dorso-basal apophysis of right male femur IV, prolateral view; (64) right male femur IV, dorsal view; (65) body, right lateral view (MCN447); (66) pair of main tubercles on mesotergal area III, frontal view (MCN450). Scale bar: $1 \mathrm{~mm}$.

with one internal apophysis bifid, with ventral or lateral branch. Ocularium with one pair of divergent spines. Main pair of tubercles of area III large and fused, with free apexes. Lateral margin of dorsal scute with tubercles in all its extension, with some larger tubercles on widest part of mesotergum. Posterior margin of dorsal scute and free tergites with one large rounded median tubercle, with one row of rounded tubercles slightly smaller than median and with scattered granules between tubercles. Pedipalps. Tibia IIi/ili ectal; IIi/Iii mesal. Tarsus IiI ectal; II mesal. Legs (Figs 68 and 69). External apical apophysis of coxa IV transversal, with two apical branches, dorsal acuminate and backwards, longer than ventral, rounded. Femur IV slightly curved inwards, with retrolateral spines almost equi- distant, increasing in size to the middle, two larger; row of prolateral spines increasing in size to the middle, apicalmost curved backwards. High dorso-basal apophysis, larger than the diameter of femur, bifid, internal branch acuminate, similar sized to external, curved downwards; base larger than branch with one tubercle on anterior face. Tarsal formula: 5, 8/10, 7, 7/8. Penis (Figs 149-151). Median seta of ventral plate small, at same direction of dorso-apical setae row. Flabellum of ventral process with projections on ventral margin and long longitudinal axis. Glans stylus with oblique apex, without projections; dorsal process long and granulate. Coloration. Uniformly darkbrown, area III darker, metatarsi and tarsi of legs lighter. Measurements. Dorsal scute: 4.8-6.1 long; 5.2-6.8 wide; legs: I: 8.3- 


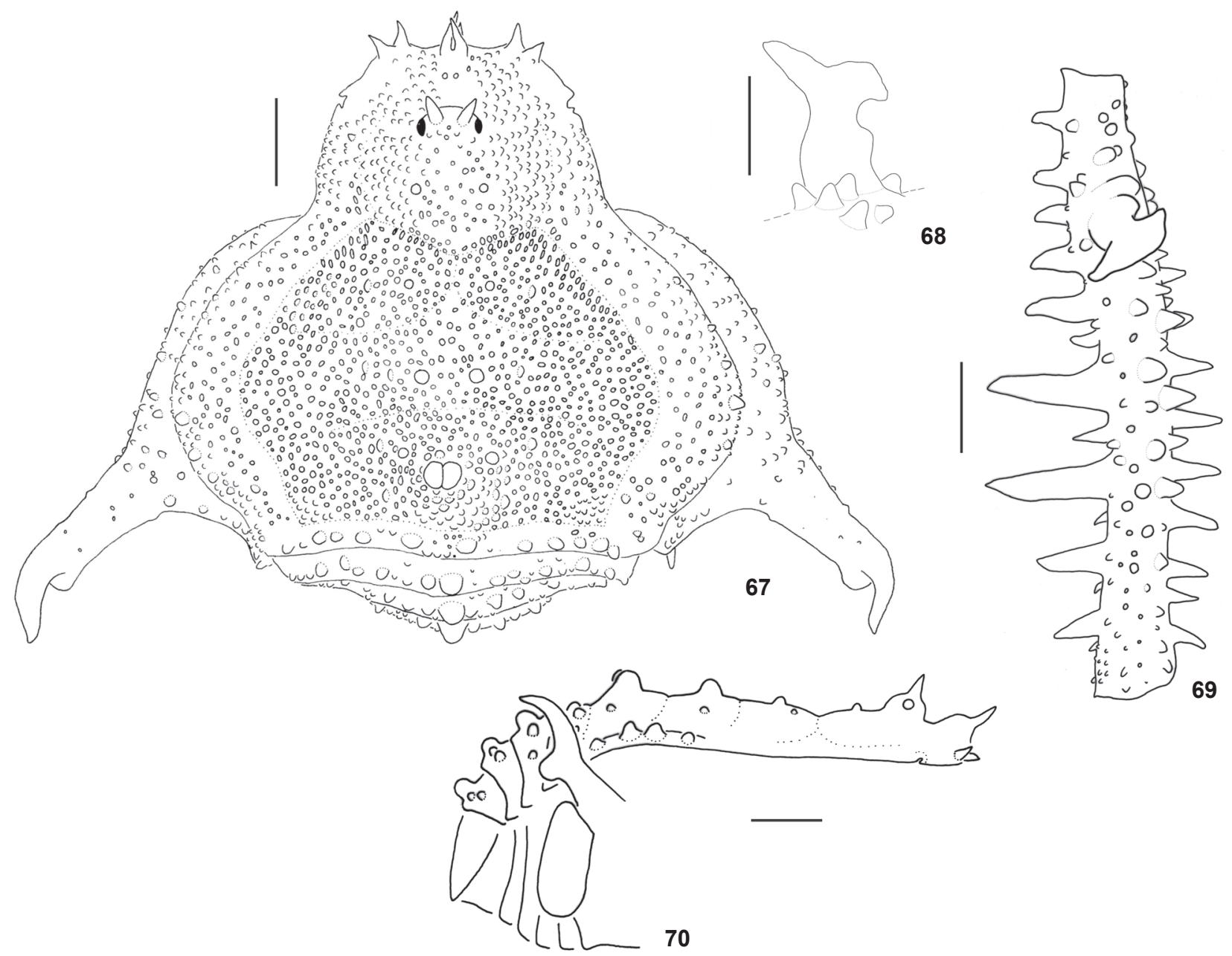

Figures 67-70. Acrogonyleptes pectinifemur: (67) dorsal habitus (MZSP978); (68) dorso-basal apophysis of right male femur IV, prolateral view (MNRJ4961); (69) right male femur IV, dorsal view (MZSP978); (70) body, right lateral view (MZSP1342). Scale bar: 1 mm.

11.2, II: 18.5-23.8, III: 14.4-17.6, IV: 19.2-26.2, male femur IV: 5.8-8.7; pedipalp: 3.2-4.7.

Female. It differs from male by having: smaller main pairs of areas tubercles; larger main spines of posterior margin and free tergites; femur IV with prolateral row of spines increasing in size apicad, larger than tubercles on the rest of article. Measurements. Dorsal scute: 4.9-6 long; 5.2-6 wide; legs: I: 8.3-10, II: 15.1-19.2, III: 13.5-15.4, IV: 18.2-21.6; pedipalp: 3.5-4.5.

Material examined. BrasiL, Santa Catarina: Florianópolis, Springmann, X.1945, 1 ma and 1 fe (MZSP978, paratypes), 2 ma and 1 fe (MZSP941, paratypes); Florianópolis, C. N. Gofferjé, II.1947, 1 ma and 1 fe (HSCP265), 1 ma and 2 fe (MZSP1342); Florianópolis (Canavieiras), C.N. Gofferjé, I.1950, 3 fe (HSCP906); Florianópolis (Costa da Lagoa), D. Pedroso, II.2002, 5 ma and 1 fe (MNRJ4961).
Acrogonyleptes spinifrons Roewer, 1917, revalid. Figs 71-81, 115, 152-158, 187

Acrogonyleptes spinifrons Roewer, 1917: 136 (fig. 32) [desc]; 1923: 508 (fig. 635) [redesc]; 1930: 360 [key]; Mello-Leitão, 1932: 317 (fig. 187) [redesc, key]; Soares \& Soares, 1949: 157 [cat]; 1984: 306 (syn. A. armatifrons (Roewer, 1917)) [syst].

Melloleitaniana curitibae B. Soares, 1943: 207 (fig. 2) [desc]; 1945a: 195 [syst]; H. Soares, 1945: 215 (fig. 2) [desc]; 1966a: 89 [cit]; 1966b: 118 [cit]; Soares \& Soares 1949: 190 [cat]; Pinto-da-Rocha \& Caron 1989: 1023 [cit]. Syn. nov.

Acrogonyleptes curitibae: Soares \& Soares 1984: 306 (figs 11-14) [redesc]; Pinto-da-Rocha, 2002: 379 (fig. 10) [cit]; Hara \& Gnaspini, 2003: (fig. 3) [cit]; Kury, 2003: 141 [cat].

Melloleitaniana riodareiensis Soares \& Soares 1945: 370 (fig. 2) [desc]; Tavares, 1980: 157 (figs 1-4) [redesc]; Soares \& Soa- 
res, 1984: 306 (syn. Acrogonyleptes curitibae) [syst].

Melloleitaniana riodariensis (misspelling): Soares \& Soares, 1949:

191 [cat]; H. Soares, 1966b: 118 [cit]; Pinto-da-Rocha \& Caron, 1989: 1023 [cit].

Diagnosis. Acrogonyleptes spinifrons is similar to $A$. pectinifemur by having large sized and divergent spines on ocularium. It differs from $A$. pectinifemur by smaller lateral spines of femur IV; shape of dorso-basal apophysis of femur (low and wide); large and oblique apical branch of external apophysis of male coxa IV. A. spinifrons is a very polymorphic species, some of the variable characters are: median and lateral apophyses on anterior margin of dorsal scute, armature of ocularium, posterior/lateral margins of dorsal scute, free tergites, mesotergal area III, femur IV, and shape of external apical apophysis of coxa IV.

Male description. Dorsum (Figs 71 and 74). Corners of anterior margin of dorsal scute with two single apophyses, internal apophysis bifid or trifid, with ventral or lateral branch, or with three apophyses (type: 2, laterally bifid). Ocularium with one pair of divergent spines. Main pair of tubercles of mesotergal area III fused in varied degrees always with free apexes or separated, they can be large or thin, high or low (type: fused and large). Lateral margins of dorsal scute with tubercles in all its extension, with some larger tubercles at wider part of mesotergum. Posterior margin of dorsal scute and free tergite I with only one row of rounded tubercles of similar size or one additional larger median rounded or conical tubercle or one spine (type: rounded tubercle); free tergites II-III with one row of rounded tubercles and one larger conical tubercle or spine, larger on tergite III; posterior margin and free tergites with scattered granules among tubercles. Pedipalps (Fig. 115). Tibia ili/IIi (Iii) ectal; IIi/II/Iiii/Iii/Ii (II) mesal. Tarsus IiI ectal; II mesal. Legs (Figs 72, 73 and 75-81). External apical apophysis of coxa IV transversal or oblique, with large apex, with two short apical branches, dorsal branch acuminate, ventral branch rounded. Femur IV curved inwards with scattered retrolateral spines of several sizes, larger in the middle region distance between these and next anterior spines larger than among other spines; row of prolateral spines increasing in size medially, apicalmost curved backwards; dorsal median tubercles larger than on rest of article. Dorso-basal apophysis small, size similar to the diameter of femur, bifid, internal branch acuminate, larger or of similar size to external branch, which is curved downwards; presence in some specimens of quadrate process at anterior base of apophysis. Tarsal formula: 5/6, 7/11, 6/7, 7. Penis (Figs 152-158). Median seta small, more ventrally placed than dorso-apical setae. Rounded flabellum of ventral process with projections on ventral margin. Glans stylus with oblique apex and without projections; dorsal process long and granulate. Coloration. Uniformly brownblackish, area III darker and metatarsi and tarsi of legs lighter. Measurements. Dorsal scute: 5.4-7.2 long; 5.2-7.4 wide; legs: I: 9.1-11.1, II: 17.5-23.6, III: 14.2-18.9, IV: 21.5-26.2; male femur IV: 5.7-6.9; pedipalp: 4.3-5.3.

Females. It differs from male by having: smaller main pairs of tubercles of mesotergal areas; larger main spines of posterior margin of dorsal scute and free tergites; femur IV with row of spines increasing in size apicad, retro and prolateral, similar, and with dorsal and ventral spines at middle basal region. Measurements. Dorsal scute: 5.3-7.3 (7.3) long; 5.5-7.8 (7.8) wide; legs: I: 8.1-13.3 (13.3), II: 16-23.4, III: 12.6-18.5, IV: 18.1-24.4; pedipalp: 3.9-5.3 (5.1).

Material examined. Brasil, São Paulo: Santos (mislabeled?), fe (SMFD1329, holotype of Acrogonyleptes spinifrons). Paraná: Tunas do Paraná (Parque Estadual Campinhos), R. Pinto-da-Rocha, XI.1989, 1 fe (MHNCI6663); Bocaiúva do Sul (Volta Grande), R. Hertel, X.1944, 2 fe (MHNCI3348/3349); ibidem, R. Hertel, IV.1944, 1 ma (MHNCI66); ibidem, R. Hertel, VI.1943, 1 ma (MHNCI68); ibidem, Hertel, X.1944, 1 ma e 2 fe (MZSP1035); Piraquara (Rincão), C. N. Gofferjé, IX.1948, 1 ma and 1 fe (HSCP35); ibidem, H. Gofferjé, VI.1950, 2 ma and 2 fe (MHNCI6163); ibidem, C. N. Gofferjé, V.1948, 1 ma and 2 fe (HSCP144); Morretes (Marumbi), Hatschbach, XII.1943, 1 fe (MHNCI67, "alótipo"); Morretes, Hatschbach, III.1946, 1 fe (MZSP1032); São José dos Pinhais, C. N. Gofferjé, I.1950, 1 ma (HSCP43); Curitiba, Pe. J. Moure, IV.1942, 1 ma (MHNCI65, holotype of Melloleitaniana curitibae); Curitiba (Rincão), C. N. Gofferjé, V.1948, 1 ma (HSCP776); ibidem, C. N. Gofferjé, IV.1948, 1 ma and 1 fe (HSCP946); Curitiba (Almirante Tamandaré, understory of bracatinga), without collector, XII.1982, 1 ma (HSCP832); Curitiba, Gengnagel, XII.1948, 1 ma and 1 fe (HSCP945); ibidem, C. N. Gofferjé, V.1948, 4 ma and 4 fe (MZSP1259); ibidem, Gengnagel, 1945, 1 ma (MZSP933); Campo Largo (Ferraria), without collector, I.1967, 1 ma and 2 fe (MHNCI); Morretes, G. Hatschbach, III.1946, 1 ma (MZSP1031); Reserva do Iguaçu (Rondinha, Faz. do Pinho), Moura-Leite \& Morato, X.1991, 1 ma (MHNCI 8076); Pinhão (Rio dos Touros), R. Pintoda-Rocha \& Barreto, XI.1991, 2 ma and 3 fe (MZSP14734); Teixeira Soares (Rio D'Areia), R. Lange, IX.1944, 1 ma (MHNCI1076, holotype of M. riodareiensis). Santa Catarina: Blumenau (Parque Natural Municipal Nascentes do Garcia), Equipe Biota, I.2003, 1 ma (IBSP5853); Rancho Queimado, A.B. Bonaldo, X.1994, 1 ma (MCN1251); Pouso Redondo, R.Pinto-da-Rocha, A.B. Kury \& A. Giupponi, III.1999; 1 ma and 3 fe (MZSP18180); Pouso Redondo (Serra Geral), R.Pinto-da-Rocha, A.B. Kury \& A. Giupponi, III.1999, 1 ma and 1 fe (MZSP18181); Paulo Lopes (Parque Estadual da Serra do Tabuleiro), Equipe Biota, I.2003, 4 ma and 1 fe (IBSP5370); Lajes, A. Castro, I.1976, 2 ma and 2 fe (HSCP791); Lajes, A. Castro, I.1976, 1 ma and 4 fe (MNRJ17382); Tubarão, E. Lerner, II.1986, 1 ma and 1 fe (MCN994). Rio Grande do Sul: Iraí, A. Lise, XI.1975, 1 ma and 2 fe (MCN336); Iraí, A. Lise, XI.1975, 1 fe (MCN449); Tenente Portela (Parque Estadual do Turvo), H. Bischoff, XI.1978, 1 ma (MCN595); Derrubadas (Parque Estadual do Turvo), A. Bonaldo, A.B. Kury \& R. Pinto-da-Rocha, II.1996, 1 ma and 1 fe (MNRJ6963); São Francisco de Paula (Potreiro Velho), A. Lise, V.1999, 1 ma and 1 fe (MCP236); Cambará do Sul, A.B. Bonaldo \& L. Moura, IV.1994, 1 ma and 1 fe (MCN1238); Torres, L. Buckup, X.1954, 4 ma and 3 fe (MCN168); Maquiné (FEPAGRO), Equipe Biota, I.2002, 3 ma and 5 fe (IBSP4403). 

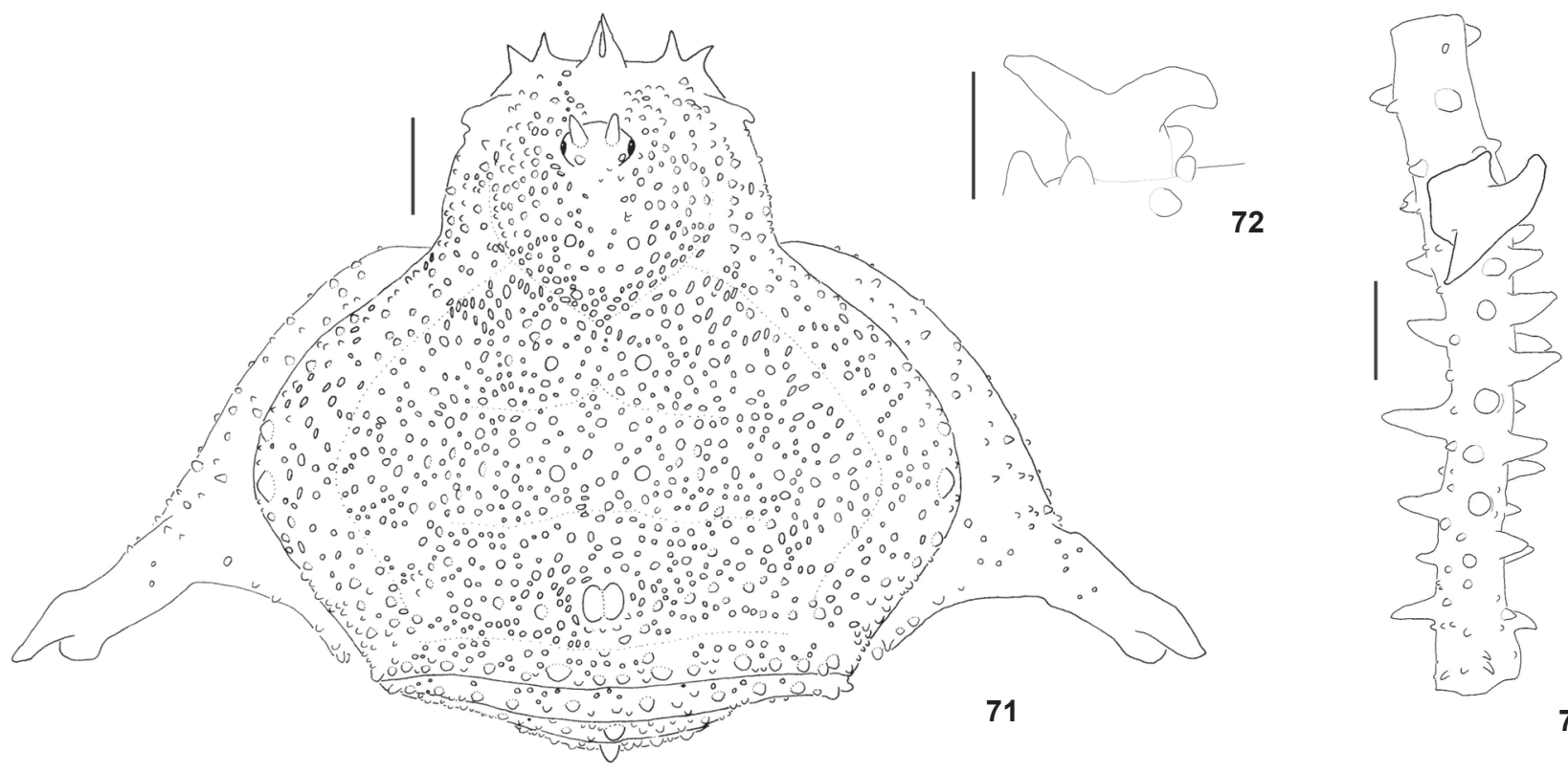

73

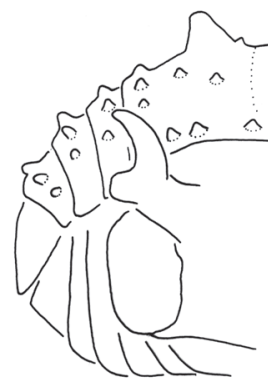

74
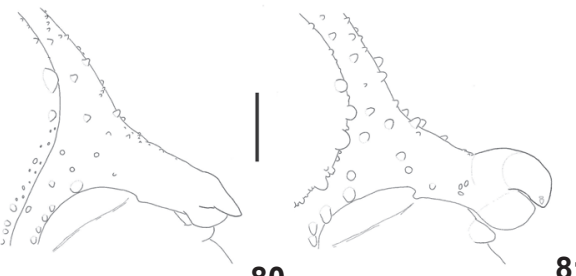

80

81

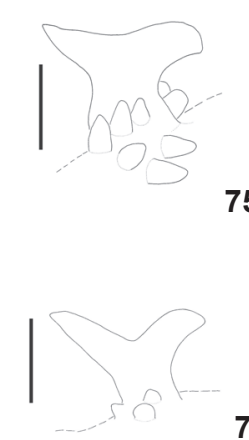

75

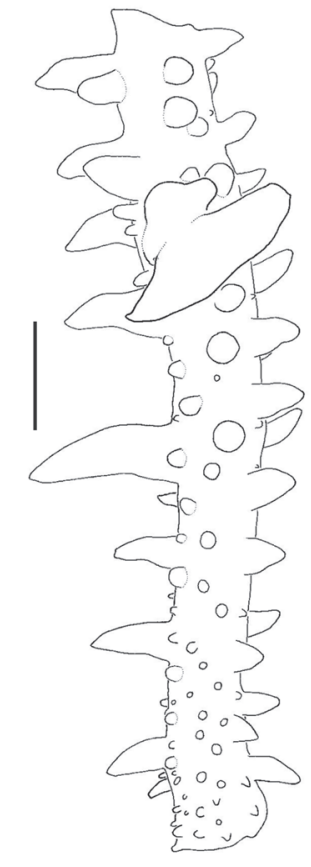

78

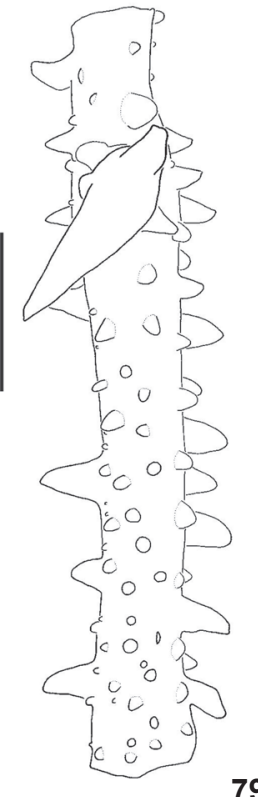

Figures 71-81. Acrogonyleptes spinifrons, male (MHCNI65): (71) dorsal habitus; (72) dorso-basal apophysis of right male femur IV, prolateral view; (73) right male femur IV, dorsal view; (74) body, right lateral view (male, IBSP5370); (75-77) dorso-basal apophysis of right male femur IV, prolateral view (MCN595, MCN168, HSCP791, respectively); (78-79) right male femur IV, dorsal view (MCN595, MHNCI172, respectively); (80-81) external apophysis coxa IV, dorsal view (MCN595, HSCP945, respectively). Scale bar: 1 mm. 


\section{Acrogonyleptes rhinoceros (Roewer, 1917) comb. nov.}

Figs 82-87, 144-145, 185

Sphaerobunus rhinoceros Roewer, 1917: 142 (fig. 36) [desc]; 1923: 536 (fig. 669) [redesc]; Mello-Leitão, 1932: 360 (fig. 224) [redesc]; Soares \& Soares, 1948: 580 [cat]; 1985a: 179 [redesc]; Kury, 2003: 139 [cat].

Diagnosis. It can be easily recognized by having a high and single tubercle on mesotergal area III, and a pair of tubercles, very low and distant from each other, on ocularium; male femur IV straight and long, armed with three retrolateral median spines. A. rhinoceros is closely related to A. exochus and A. granulatus by having pedipalpal femur thinner than remaining articles, biconvex tarsus; two single apophyses on corners of anterior margin of dorsal scute; one larger tubercle on lateral margin of dorsal scute.

Male description. Dorsum (Figs 82 and 85-87). Two single apophyses on corners of anterior margin of dorsal scute. Ocularium with one pair of small rounded tubercles, distant from each other. Mesotergal area III with one large high tubercle which is rounded at apex. Lateral margin of dorsal scute with one row of similar-sized tubercles and one larger acuminated or rounded tubercle (type: long and acuminate), which can be longer than wide, located on wider region of mesotergum, with one or two slightly smaller tubercles (type: 1) in some specimens. Posterior margin of dorsal scute and free tergites with rounded, similar-sized tubercles; posterior margin unarmed, free tergites I-III with one large median spine, one pair of paramedian smaller tubercles or some decreasing in size externally. Pedipalps. Femur and trochanter elongated, with diameter narrower than tibia and tarsus diameter. Tarsus biconvex. Tibia IIi ectal and mesal. Tarsus II ectal and mesal. Legs (Figs 83 and 84). External apical apophysis of coxa IV almost transversal, elongated, with wide apex, bifid; dorsal branch acuminate, larger, ventral branch rounded; only granules on internal apex of coxa IV. Femur IV straight and long with 3-5 (type: 3) large median retrolateral spines, slightly curved backwards, some small at apex and base; row of prolateral spines increasing apicadly, apical spine curved distally. Dorso-basal apophysis of similar size to femur, bifid, with similar-sized branches, internal acuminate, external with rounded apex. Tarsal formula: 5, 8/12, 7/8, 8/9. Penis (Figs 144 and 145). Ventral plate with shallow, narrow and U-shaped apical concavity; lateral lobe large, longer than wide; median seta as small as ventroapicalmost setae, equidistant from dorso-apical and ventral setae. Ventral process flabellum bearing projections on ventral margin and with large long longitudinal shaft. Glans stylus with oblique apex and subapical ventral projections. Coloration. Brown; legs, except for femur IV, lighter; pedipalps yellowish. Measurements. Dorsal scute: 3.6-4.9 (4.7) long; 3.7-5.5 (5.4) wide; legs: I 7.5-9.7 (8.9), II 20-25.7, III 13.5-16.8, IV 19.3-24.1, male femur IV: 5.6-7.0 (6.4); palp: 4.5-6.1 (5).
Female. It differs from male by having: larger main spines of posterior margin of dorsal scute and free tergites; lateral margin with larger conical main tubercle; femur IV with row of spines scattered at middle basal retrolateral and dorsal region. Measurements. Dorsal scute: 4-4.4 long; 3.9-4.7 wide; legs: I: 8.5-9, II: 23.7-26.1, III: 15.8-16.2, IV: 21.5-24.6; pedipalp: 5-5.6.

Material examined. BRASIL, [São Paulo]: Santos (mislabeled?), 1 ma (SMFD1334, holotype of Sphaerobunus rhinoceros). Santa Catarina: Ilhota (Parque Botânico Morro do Baú), R. Pinto-daRocha, R. S. Bérnils \& R. Lingnau, IV.1999, 4 ma and 1 fe (MZSP18653); Blumenau (Parque Ecológico Spitzkopf), R. Pintoda-Rocha, R. S. Bérnils \& R. Lingnau, III.1999, 13 ma and 6 fe (MZSP18385), 3 ma (MZSP18322); ibidem, A. Bonaldo, A. B. Kury \& R. Pinto-da-Rocha, II.1996, 1 ma, 4 fe e 1 i (MZSP14758); Blumenau (Parque Natural Municipal Nascentes do Garcia), Equipe Biota, I.2003, 1 ma and 1 fe (IBSP5894); Paulo Lopes (Parque Estadual da Serra do Tabuleiro), Equipe Biota, I.2003, 1 ma (IBSP5232), 1 ma (IBSP5444).

\section{Acrogonyleptes cheguevarai sp. nov. Figs 88-91, 116, 159-162, 188}

Diagnosis. It differs from other genus species by having trifid apophyses on corners of anterior margin of dorsal scute, one large median spine anterior to ocularium, mesotergal area III with 3-4 fused tubercles forming a robust elevation, very wide external apical apophysis of coxa IV, one dorso-apical apophysis on femur IV, and metatarsus with enlarged distal region. It shares low convergent tubercles on ocularium and low, similar sized tubercles on lateral margin of dorsal scute with some species of Hernandaria.

Male description. Dorsum (Figs 88 and 91). Corners of anterior margin of dorsal scute with two apophyses, internal trifid; pair of median apophyses on anterior margin larger than those of corners; covered with some small spines between anterior margin and ocularium. Ocularium with one pair of close and weak tubercles, with rounded apex slightly curved inwards. Prosomal area behind ocularium, mesotergal areas I and II with one main pair of rounded tubercles, II elongated longitudinally, larger on areas I-II; III with two pairs, one in front of other, or with one anterior pair and posterior tubercle (type: 2 pairs) fused into one enlarged protuberance with rounded apexes; I-III with tubercles of several sizes in each side. Lateral margin of mesotergum with similar-sized scattered tubercles. Posterior margin and free tergites with one row of smaller rounded tubercles and one larger median conical tubercle, decreasing in size from posterior margin to free tergite III, with scattered granules. Pedipalps (Fig. 116). Tibia Ii ectal, I mesal. Tarsus IiI ectal, II mesal. Legs (Figs 89 and 90). External apical apophysis of coxa IV enlarged and transversal with two or three (2) similar-sized short apical acuminated branches. Femur IV short with retrolateral spines increasing in size until apical 1/3, last two slightly curved backwards; a few apical spines smaller than basal; prolateral row of spines increasing in size apicadly, smaller than 


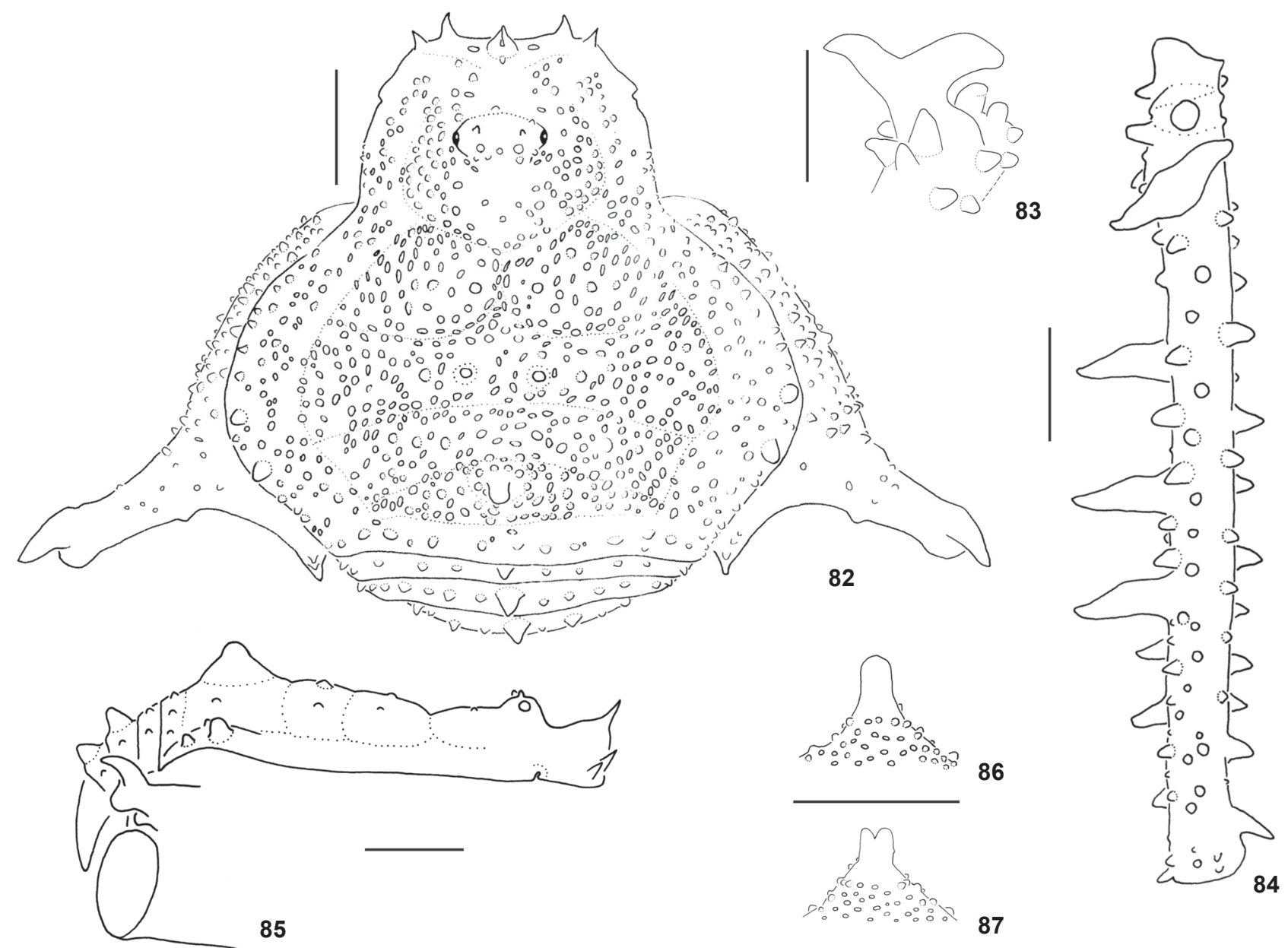

Figures 82-87. Acrogonyleptes rhinoceros: (82) dorsal habitus (MZSP18385); (83) dorso-basal apophysis of male right femur IV, prolateral view (MZSP18653); (84) male right femur IV, dorsal view (MZSP18385); (85) body, right lateral view (MZSP18653); (86-87) main tubercle of mesotergal area III (IBSP5232, IBSP5894, respectively). Scale bar: $1 \mathrm{~mm}$.

apical retrolateral spines; apical prolateral spine curved backwards; dorso-basal apophysis high, larger than diameter of femur, curved frontwards and bifid, with two equally sized upwards curved acuminated branches; one tubercle at base of apophysis on anterior face; one dorso-apical apophysis formed by several tubercles, slightly smaller than basal apophysis. Metatarsus IV with calcaneus broader than astragalus. Tarsal formula: 4/5 (5), 6/7 (7), 6, 6/7 (7). Penis (Figs 159-162). Ventral plate apexes curved inwards; apical concavity deeper than wide; basal setae close to each other in horizontal row, with ventralmost seta much smaller, distant from the others, inserted in lateral large lobe; median seta as small as ventro-apicalmost setae, equidistant from dorso-apical and ventral setae. Stylus with oblique apex and without projections; ventral process with flabellum bearing projections on ventral margin and longitudinally enlarged shaft. Coloration. Uniformly blackish; tarsi of legs and calcaneus of leg IV light brown; pedipalps yellowish. Measurements. Dorsal scute: 4.0-5.1 (5.1) long; 3.7-4.9 (4.9) wide; legs: I: 4.7-7.4 (7.4), II: 8.7-15.2 (15.2), III: 7.3-11.4 (11.4), IV: 10.715.4 (15.4), male femur IV: 2.5-4.4 (4.4); pedipalp: 2.5-4.4 (3.1).

Female. It differs from male by having: smaller main pairs of tubercles on mesotergal areas; tubercles of area III close to each other, or only posterior pair fused; larger tubercles of posterior margin and free tergites, eventually these tubercles may become conical increasing in size towards the middle, femur IV with a ventro-prolateral row of larger tubercles, increasing in size apicadly. Measurements. Dorsal scute: 4.2-5.5 long; 3.75.3 wide; legs: I: 5.1-6.9, II: 8.8-14.7, III: 7.1-11.7, IV: 10.6-16.4; pedipalp: 2.4-3.7.

Material examined. BRASIL, Rio Grande do Sul: Cambará do Sul, A. B. Bonaldo, XI.1993, 1 ma and 2 fe (MCN1205, paratypes); São Francisco de Paula, A. Lise, I.1981, 1 ma (MCN712, paratype); 


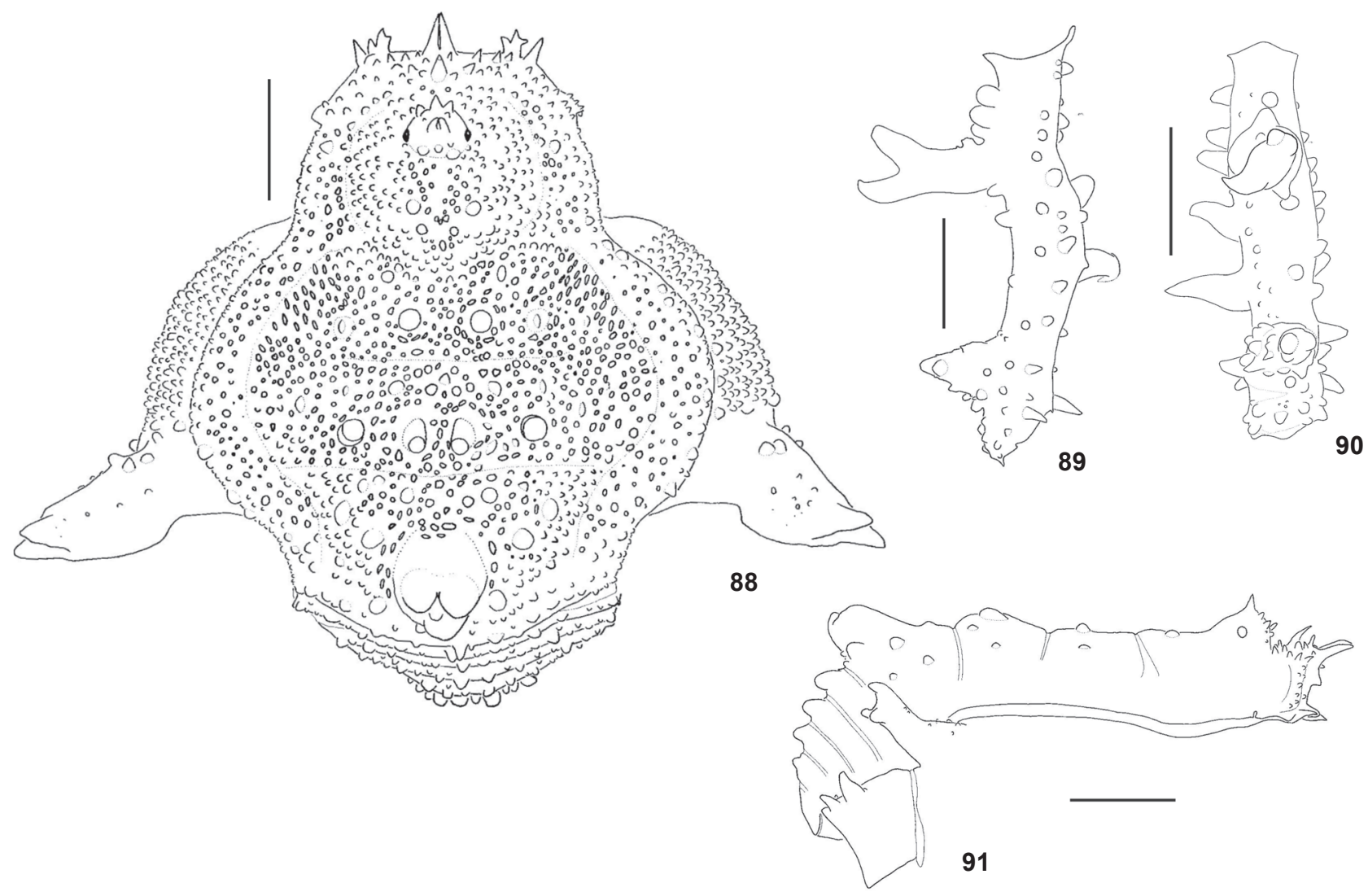

igures 88-91. Acrogonyleptes cheguevarai sp. nov.: (88) dorsal habitus (MCP); (89) right male femur IV, prolateral view (MCN712); (90) right male femur IV, dorsal view (MCP); (91) body, right lateral view (MCN712). Scale bar: $1 \mathrm{~mm}$.

Torres (São Pedro), Lise, A., XI.1976, 1 fe (MCN448, paratype); Maquiné (FEPAGRO), Equipe Biota, I.2002, 1ma and 1 fe (IBSP, ma holotype); ibidem, same data, 1 fe (MZSP29093, paratype); ibidem, 4 ma and 2 fe (MZSP28545, 28557, 28558, paratypes); Canela (Barragem dos Bugres), A. Silva, XI.1998, 1 fe (MCN1384, paratype); without data (MCP, paratypes).

Etymology. In honor of Che Guevara (1928-1967), the famous Argentine socialist revolutionary, who undertook the battle for the people's freedom in Latin America and Africa.

\section{Multumbo Roewer, 1927}

Multumbo Roewer, 1927: 351 [desc]; 1932: 317 [redesc, key]; Mello-Leitão, 1932: 117 [redesc]; 1935: 97 [key]; 1949: 24 [syst]; Soares \& Soares, 1948: 608 [cat, redesc, key]; Kury, 1992: 283 [redesc]; 2003: 134 [cat]; Pinto-da-Rocha, 1994: 29 [cit].

Type species: Multumbo terrenus Roewer, 1927, by monotypy.

Diagnosis. Sexual dimorphism: swollen male basitarsus; male leg IV armature present or absent. All body tubercles and granules rounded, except for main pair of ocularium tubercles (only apex rounded). Pair of median apophyses on anterior margin of dorsal scute smaller than those of corners, slightly separated and convergent, touching each other, or not, at the apex. Prosoma with one fold between ocularium and lateral margin, as a sub-anterior margin, with almost smooth anterior region until anterior margin of scute, without camouflage of debris. Ocularium wide, high and enlarged with one pair of high tubercles, rounded at apex, directed obliquely frontwards. Three mesotergal areas. Granules concentrated on areas close to sulci. Area III with main pair of separated tubercles. Lateral margin of dorsal scute with a few larger tubercles on wider region of mesotergum. Posterior margin of dorsal scute and free tergites with similar-sized tubercles. Genital and stigmatic areas deeper than coxae and posterior margin. Density of granules reduced on stigmatic and genital areas, with one pair of tubercles at base of genital area and without camouflage of debris. Pedipalpal femur with diameter similar to that of other articles. Legs with small and scattered tubercles, except femur IV of M. dimorphicus. Tarsus I with six articles. Penis with ventral plate longer than wide, with oblique side and U-shaped apical concavity. Basal setae of ventral plate with smaller ventralmost seta, inserted at short and wide lateral lobe. 


\section{Multumbo terrenus Roewer, 1927 Figs 92-94, 168-169, 176, 189}

Multumbo terrenus Roewer, 1927: 351 (fig. 17) [dexc]; 1932: 317 (fig. 33) [redesc]; Mello-Leitão, 1932: 118 (fig. 65) [redesc]; Soares \& Soares, 1948: 608 [cat]; Soares \& Bauab-Vianna, 1972: 204 [cit]; Kury, 1992: 283 (figs 7-11) [redesc]; 2003: 134 [cat].

Redescription of male and female. Dorsum (Figs 92 and 93). Anterior margin of dorsal scute with one pair of median convergent apophyses, not touching each other at apex, smaller than those of corners; two apophyses on corners, the external one single or bifid (single). All body tubercles and granules rounded, except for main pair of high, enlarged and parallel ocularium tubercles with rounded apexes. Oblique, and anteriorly slightly curved inwards, prosomal fold of tegument placed between ocularium and ozopore, not reaching lateral margin of dorsal scute, and with 1-3 tubercles (type: 1); anterior region of prosoma smooth or with few scattered granules (type: smooth) and without camouflage of debris. Prosoma behind ocularium, mesotergal areas I-III with one pair of main tubercles, far from each other on area I, larger than those of prosoma on I-II, largest on III; I-III with one additional pair of paramedian tubercles, similar in size to prosoma tubercles. Median longitudinal mark on mesotergum lacking pigmentation and limited by one row of granules, similar to sulci. Granulation concentrated near sulci of areas and on sides of ocularium. Lateral margin of dorsal scute with lower density of granulation, higher on prosoma; 1-5 (1 and 2) tubercles on wider part of mesotergum. Posterior margin and free tergites with one row of scattered tubercles, larger at median region and posterior segments. Venter. Similar-sized granules to those on dorsal scute, one row on free sternites and uniformly distributed on coxae, except for proximal smooth region; stigmatic and genital areas with lower density of granules, with one pair of tubercles at base of genital area; genital operculum granulate. Pedipalps. Diameter of femur similar to that of other articles. Tibia II mesal; IIi ectal. Tarsus II mesal; IIi ectal. Legs (Fig. 94). Leg I with larger tubercles on venter of trochanter and femur. Other leg articles with small scattered tubercles. Swollen male basitarsus. Tarsal formula: 6, 10/12 (10/11), 7, 7/8 (8). Penis (Figs 168 and 169). Ventral plate wide at basal setae region in dorsal view, with straight and oblique sides; apexes curved slightly inwards. Median seta slightly smaller than ventro-apical pair; apical setae larger at apex, distant from smaller ones; ventralmost basal seta much shorter than other basal setae, 4 inserted in one horizontal row on lateral lobe. Stylus with oblique apex and ventral projections; ventral process flabellum bearing projections on apex. Coloration. Uniformly brownish-black; legs light-brown; pedipalps, chelicerae, trochanter I, apex of metatarsi and tarsi yellowish. Measurements. Dorsal scute: 4.9-5.4 (5.4) long; 4.4-5.3 (4.9) wide; legs: I: 8.3-10.6 (10.1), II: 24.8-28.8 (24.9), III: 16.7-19 (16.7), IV: 24.2-28.4 (24.2), femur IV: 7.5-8.5 (8.5); pedipalp: 3.9-5 (5).
Material examined. Brasil, Rio de Janeiro: Nova Friburgo (Rio Grande de Cima, Fazenda São João), A. B. Kury \& R. Pintoda-Rocha, X.1988, 1 fe (MNRJ6330); Teresópolis, 1 fe (SMFD1425); Teresópolis (Fazenda Vale da Revolta), R. Sachsse, II.1989, 1 ma (MNRJ6424); Teresópolis (Parque Nacional da Serra dos Órgãos), A. Kury; A. Giupponi, D. Pedroso \& V. Orrico, VIII.2005, 2 ma (MNRJ16196); Silva Jardim (Aldeia Velha, Fazenda Bom Retiro), A. B. Kury, M. Khalil \& A. Duran, I.1994, $1 \mathrm{ma}$ and 1 fe (MNRJ6843); Cachoeiras de Macacu (Boca do Mato), R. Pinto-da-Rocha \& A.B. Kury, X.1988, 1 ma (MHNCI6389); Guapimirim (Estação Ecológica Estadual Paraíso), R. Pinto-da-Rocha \& R.S. Bérnils, VII.1996, 2 ma and 1 fe (MZSP15493); Guapimirim (Parque Nacional da Serra dos Órgãos, near residential Garrafão), A. F. Barbosa, X.2001, 1 ma (MNRJ4686); Rio de Janeiro, 1 ma and 1 fe (SMFD259, lectotype ma and paralectotype fe, here designated).

\section{Multumbo dimorphicus DaSilva \& Kury, 2007}

Fig. 189

Multumbo dimorphicus DaSilva \& Kury, 2007: 32, figs 1-9.

Diagnosis (DASILVA \& Kury 2007). It differs from M. terrenus by having the conspicuous sexual dimorphism on armature of leg IV.

Material Examined. BrasiL, Rio de Janeiro: Santa Maria Madalena (Parques Estadual do Desengano, Serra da Rifa), A.B. Kury, A.P.L. Giupponi, M. Baptista, III.1998, 1 ma and 2 fe (MNRJ17383, holotype ma and paratypes); Nova Friburgo (Serra Nova Friburgo), 11-12.X.1996, S. Ide, 1 ma (MZSP29085); (Área de Proteção Ambiental do Sana), D. Pedroso \& A. Pérez, VII.2002, 1 ma and 2 fe (MNRJ11353, paratypes); (Mury, Debossam), R.S. Bérnils \& P. Labiak, 29.VII.1996, 3 ma (MZSP29025); (Macaé de Cima, sítio David Miller), G. Machado \& S. Koehler, 20-22.X.1999, 2 ma (MZSP21265); ibidem, same data, 5 fe (MZSP21260).

\section{Piassagera Roewer, 1928}

Piassagera Roewer, 1928:123 [desc]; 1932: 322 [redesc, key]; Giltay, 1930: 242 [redesc]; Mello Leitão, 1932: 115 [redesc]; 1935: 95 [key]; 1949, 24 [syst]; Soares \& Soares, 1948: 614 [cat, redesc, key]; Kury, 1992: 280 (figs 1-6, 20-21) [redesc]; Kury, 2003: 136 [cat]; Pinto-da-Rocha, 1994: 29 [cit].

Type species: Piassagera brieni Roewer, 1928, by monotypy.

Diagnosis. Sexual dimorphism: swollen male basitarsus I. Body with high density of yellow granules. Anterior margin of dorsal scute with single pointed median apophysis. Ocularium low with one pair of low and weak tubercles. Smooth anterior region of ocularium. Three mesotergal areas. Areas of mesotergum with main pair of tubercles, not very distinguishable from granules. Area III with main pair of separated tubercles. Lateral margin with similar granulation to mesotergum. Granulate posterior margin of dorsal scute 

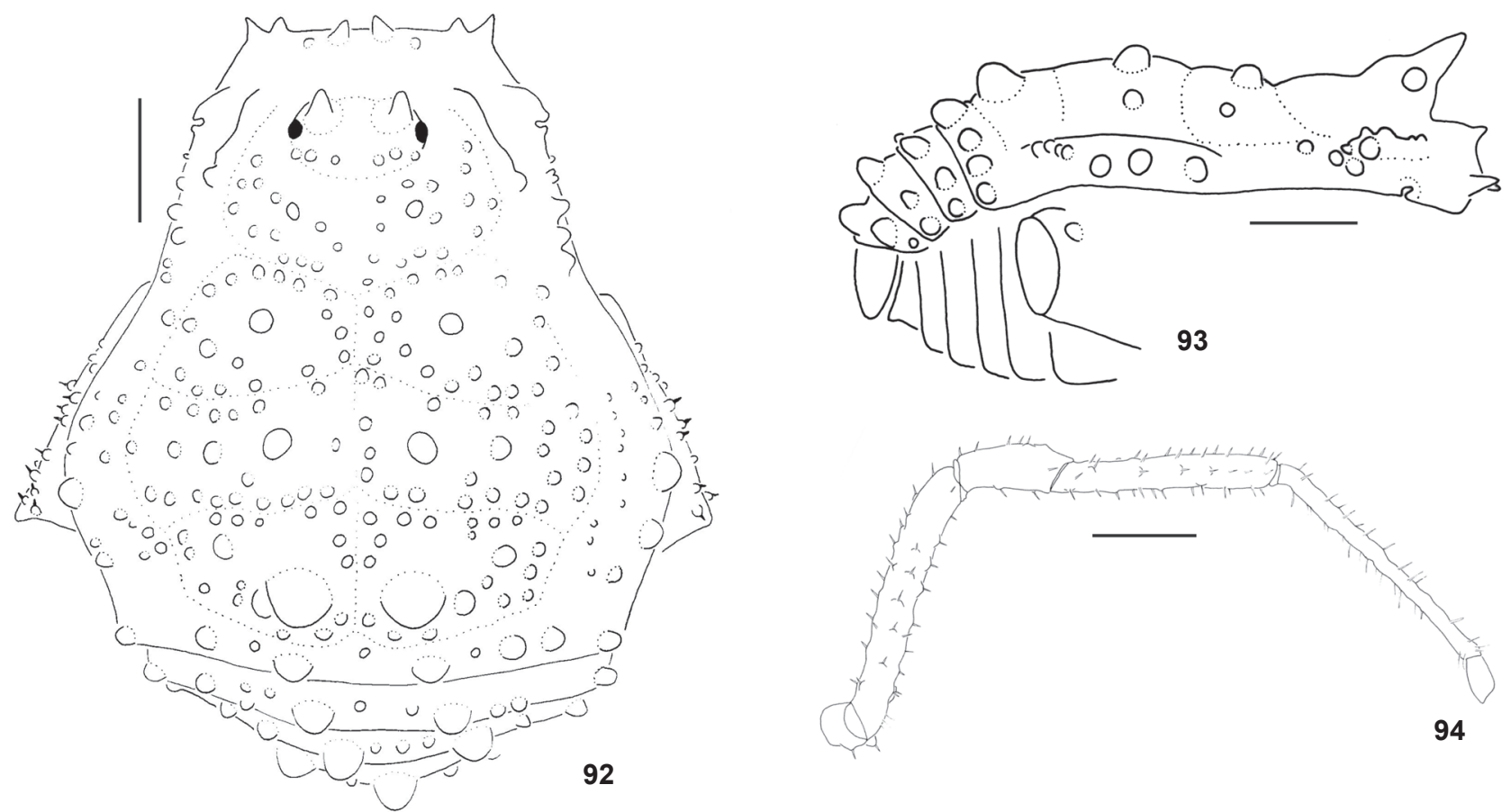

Figures 92-94. Multumbo terrenus: (92) dorsal habitus (female paralectotype, SMFD259); (93) body, right lateral view, male (MHNCI6839); (94) trocanther-tarsus of right leg I, retrolateral view, male (MZSP15493). Scale bar: $1 \mathrm{~mm}$.

and free tergites I-II. Huge granulate spine on free tergite III, almost the length of dorsal scute. Density of granules reduced on stigmatic and genital areas with one pair of tubercles at base of genital area. Pedipalp femur diameter similar to that of other articles. Legs long, thin, with weak tubercles. Tarsus I with five articles. Penis with ventral plate as long as wide, with apical U-shaped concavity. Basal setae of ventral plate with smaller ventralmost seta, inserted in one oblique row on the short and wide lateral lobe.

\section{Piassagera brieni Roewer, 1928}

Figs 95, 96, 163-165, 182, 186

Piassagera Brieni Roewer, 1928:123 (figs 1-2) [desc].

Piassagera brieni: Giltay, 1930: 243 (fig. 4) [redesc]; Mello Leitão, 1932: 115 (fig. 65) [redesc]; Roewer, 1932: 322 (figs 3839) [redesc]; Soares \& Soares, 1948: 614 [cat]; Kury, 1992: 281 (figs 1-6, 20-21) [redesc]; 2003: 136 [cat]; Kury \& Pintoda-Rocha, 2007: 197(fig. 4.29.h).

Redescription of male and female. Dorsum (Figs 95 and 96). Anterior margin of dorsal scute with single pointed median apophysis; two apophyses on corners, similar in size to median. Ocularium with one pair of low rounded or high cylindrical tubercles (type: low), far from each other. Uniformly dense granulation in entire dorsal scute, except for smooth prosomal anterior region of ocularium. Prosoma behind ocularium with one pair of tubercles; mesotergal areas without prominent tubercles. Lateral margin with tubercles close to each other on prosoma, near sulcus I. Posterior margin of dorsal scute and free tergites I-II with granules smaller than rest of dorsal scute, with one pair of slightly larger tubercles; free tergite III with very large granulated spine, similar in length to dorsal scute, with one row of larger granules close to each other on lateral margins. Venter. Granules in rows on free sternites, posterior margin of stigmatic area with lower density of granules than free tergites; coxa IV with few larger granules; stigmatic and genital areas with few granules, with one pair of tubercles at base of genital area; genital operculum with few granules at apex. Pedipalps. Diameter of femur similar to that of other articles. Tibia Iili mesal; IiI/IiIi (IiIi) ectal. Tarsus IiI mesal; IiI ectal. Legs. All legs elongated and thin with scattered tubercles. Swollen male basitarsus. Tarsal formula: 6, 10/13 (11), 7, 7/9 (8). Penis (Figs 163-165). Apexes of ventral plate directed slightly inwards; median seta slightly larger than two ventro-apical setae, distant from the dorsoapical setae group and placed slightly more ventrally; ventralmost basal seta much shorter than other basal setae, organized in one row almost horizontally inserted in lateral lobe. Stylus with oblique apex and small ventral subapical projections; ventral process with flabellum bearing projections on ventral margin. Coloration (Fig. 182). Reddish-brown, with yellow granules and tubercles; legs and pedipalps yellowish, 

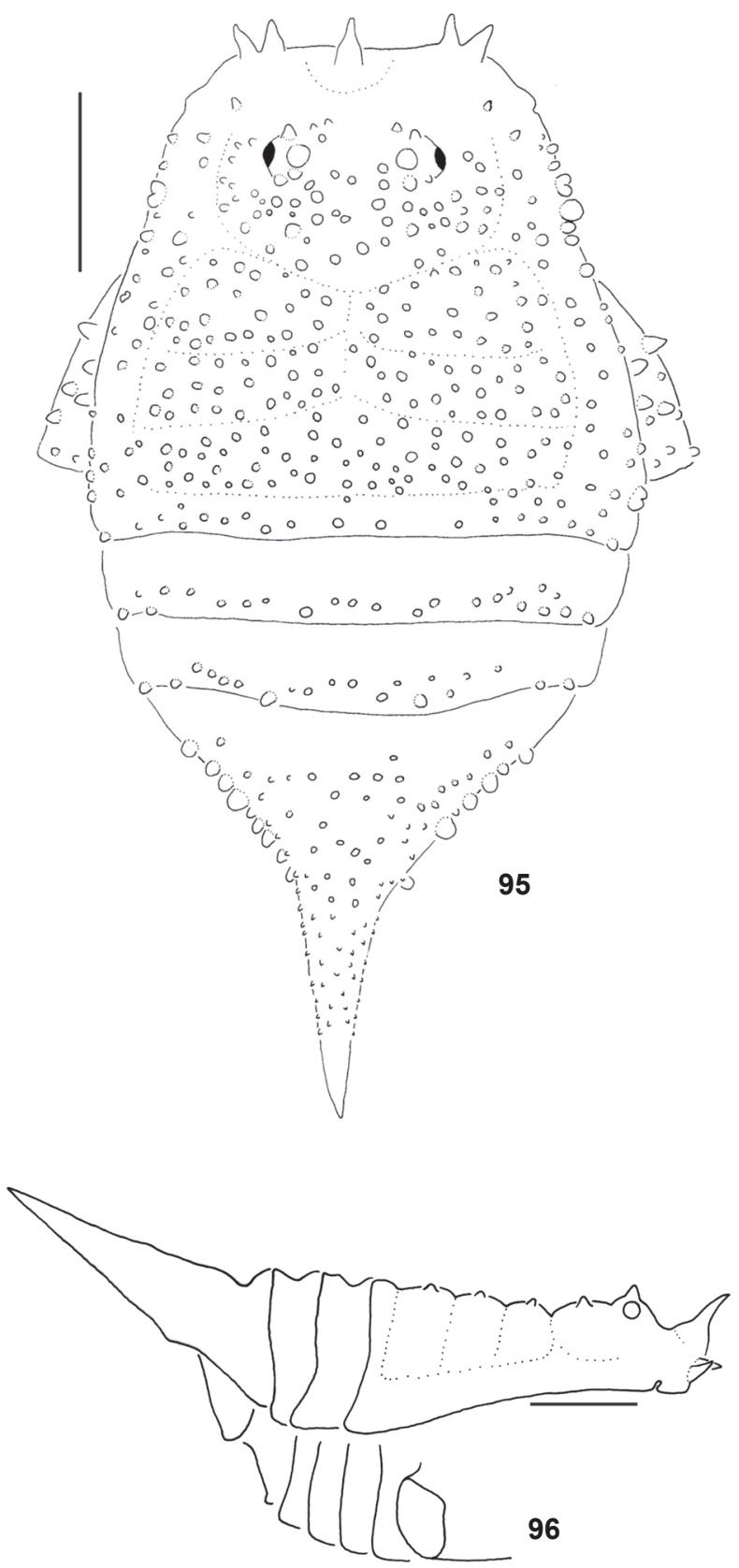

Figures 95-96. Piassagera brieni: (95) dorsal habitus (MZSP14015); (96) body, right lateral view (MZSP14005). Scale bar: $1 \mathrm{~mm}$.

both with black reticulate pigmentation; spine of free tergite III blackish. Measurements. Dorsal scute: 2.5-3.4 (2.7) long; 2.5-3.3 (3.3); legs: I: 7.9-9 (8.8), II: 21.8-26.3 (24), III: 13.715.8, IV: 19.4-23.4 (21), femur IV: 6.1-7.8 (6.8); pedipalp: 3.74.3 (4.1).

Material examined. BRASIL, São Paulo: Salesópolis (Estação
Biológica de Boracéa), S.A. Vanin, II.1973, 1 ma (MZSP12032); ibidem, C. Yamamoto, 1-4.VI.1997, 1 ma (MZSP22169); ibidem, Expedição MZSP, X.1982, 1 ma and 1 fe (MZSP14005); ibidem, L.R. Fontes \& P. Terra, I.1979, 1 ma and 1 fe (MZSP21436); ibidem, P. Biasi, II.1961, 3 ma and 1 fe (MZSP10592); Cubatão (Piassagüera), 1 ma (SMFD991, holotype), (Brien, X.1922 (Kury, 1992); Guarujá (Morro da Praia de Iporanga), M.B. DaSilva et al., 6.III.2004, 4 ma and 3 fe (MZSP22896); São Paulo (P.E. Serra do Mar, Núcleo Curucutu), T. Pavão, VIII.2003, 1 ma (MZSP29094); Bertioga (Vale do rio Itapanhaú), M.B. DaSilva \& A.A. Nogueira, XII.2004, 4 ma and 4 fe (MZSP22875).

\section{Pseudotrogulus Roewer, 1932}

Pseudotrogulus Roewer, 1932: 277, 308 [desc, key]; Mello-Leitão, 1935: 97 [key]; Soares \& Soares, 1948: 615 [cat, redesc, key]; Kury, 1992: 285 [redesc]; 2003: 137 [cat]; Pinto-daRocha, 1994: 29 [cit]; Firmo \& Pinto-da-Rocha, 2002: 173, 176 [redesc, syst].

Type species: Pseudotrogulus telluris Roewer, 1932, by monotypy.

Diagnosis. Without sexual dimorphism (except $P$. funebris with dimorphism on basitarsus I). Whitish tubercles and/or granules on dorsal scute and/or legs. One or two convergent median apophysis on anterior margin of dorsal scute. Prosoma with one oblique folding between ocularium and lateral margin, as a sub-anterior margin, anterior region of dorsal scute without camouflage of debris, almost smooth (except Pseudotrogulus trotskyi sp. nov.). Ocularium high and enlarged, with convergent or parallel, large frontward directed tubercles (except Pseudotrogulus trotskyi sp. nov.). Three mesotergal areas (except Pseudotrogulus trotskyi sp. nov. with four areas). Area III with main pair of tubercles separated. Lateral margin with a few larger tubercles on wider region of mesotergum (except Pseudotrogulus trotskyi sp. nov.). Posterior margin and free tergite I with some larger tubercles or spines and free tergites II-III with one median larger tubercle or spine (except Pseudotrogulus trotskyi sp. nov.). Venter almost smooth and without camouflage of debris, except distal coxae and posterior stigmatic area. Genital and stigmatic areas deeper than coxae and posterior margin of stigmatic area (except $P$. pagu sp. nov.). Ventral part of coxae and posterior margin of stigmatic area densely covered with high granules (except $P$. pagu sp. nov.). Density of granules reduced on stigmatic and genital areas, with one pair of tubercles at base of genital area (except Pseudotrogulus trotskyi sp. nov.). Diameter of pedipalpal femur similar to other articles. Ventral tubercles of femur I larger than those of other legs. Whitish ventral tubercles higher on other femora (except $P$. telluris). Penis with a ventral plate as long as wide, with U-shaped apical concavity. Ventralmost seta of basal group of ventral plate smaller, in an oblique row inserted on short and wide lateral lobe. Tarsus I with five articles (except Pseudotrogulus trotskyi sp. nov., 3-segmented). 


\section{Key for Pseudotrogulus}

1. Four areas on mesotergum; main pair of ocularium tubercles low and weak; anterior margin of dorsal scute covered by large tubercles between median and lateral apophyses; tarsal formula: 3, 5, 5, 5 (Figs 109-111) Pseudotrogulus trotskyi sp. nov.

$1^{\prime}$. Three areas on mesotergum (Figs 97 and 105); main pair of ocularium tubercles high (Figs 98 and 107); Anterior margin of dorsal scute with few small scattered tubercles or smooth between median and lateral apophyses (Figs 95 and 97); tarsal formula: 5, 7, 6, 6 .. 2

2. Main pair of tubercles of mesotergal area III and median tubercle of free tergite III rounded (Figs 100-103); prosomal folding on ocularium side with elongated and enlarged tubercles fused at base (Figs 101 and 175)

3

2 '. Main pair of tubercles of mesotergal area III and median tubercle of free tergite III conical (Figs 97 and 107); prosomal folding on ocularium side with unfused conical tubercles (Figs 97 and 105).....

3. Posterior margin of dorsal scute with high density of white side by side granules; femora of legs II-IV with larger ventral tubercles (Figs 100-101 and 184).... P. mirim

3'. Posterior margin of dorsal scute with scattered brown granules; femora of legs II-IV without larger tubercles (Figs 102-104) P. telluris

4. Most granules whitish; very enlarged, conical and granulate tubercle on free tergite III; ocularium tubercles convergent (Figs 97-99 and 183) P. funebris

4'. Granules same color as tegument, concentrated near sulci of mesotergal areas; free tergite III with three slightly larger tubercles than those of free tergite II; parallel tubercles on ocularium (Figs 105-108) P. pagu sp. nov.

\section{Pseudotrogulus funebris Firmo \& Pinto-da- Rocha, 2002}

Figs 97-99, 166-167, 183, 189

Pseudotrogulus funebris Firmo \& Pinto-da-Rocha, 2002: 173 [desc], figs 1-6.

Diagnosis. Differs from other Pseudotrogulus species by having a high density of whitish granules on dorsal scute; whitish conical tubercles adjacent on lateral margin; enlarged conical and granulate tubercle on free tergite III. It is the only species of the genus with eight tarsomeres on leg IV.

Redescription of male and female. Dorsum (Figs 97 and 98). Anterior margin of dorsal scute with one pair of median parallel apophyses; 2-3 (type: 3) apophyses on the corners, similar in size to median. Ocularium high with one pair of enlarged convergent tubercles, covering dorsal region of ocularium. Prosomal folding of tegument curved inwards, placed between ocularium and ozopore, distant from lateral margin; with 4-5 conical tubercles. Prosoma behind ocularium with or without one pair of tubercles (type: one pair); mesotergal areas I-II with one pair of slightly larger tubercles than those of ocularium, those of area I distant from each other; III with one pair of large and conical tubercles, one pair of paramedian tubercles similar in size to those of I-II. Granulation very dense, except for anterior region of prosoma, sides of ocularium, median region from ocularium to main pair of tubercles of III, sides of III, anterior angles of I, and posterior angles of III. Lateral margin with 1-3 (type: 3) larger conical tubercles, almost fused, at wider region of dorsal scute. Posterior margin of dorsal scute with one pair and free tergites with three tubercles, those in center of tergites II-III conical and straight, the remaining curved backwards; median tubercle of free tergite III enlarged and covered by granules; free tergite III with one row of granules which are slightly larger and close to each other on posterior margins. Venter. Stigmatic and genital areas with density of granules lower than coxae, with one pair of tubercles at base of genital area; genital operculum with a few granules at apex. Pedipalps. Tibia IIi mesal, IiIi ectal. Tarsus IiI mesal, IiI ectal. Legs (Fig. 99). Leg I with enlarged tubercles on venter of trochanter and femur; femur I with 9-12 (10) ventral tubercles, slightly larger than dorsal; basitarsus I swollen on male. Remaining leg articles with small scattered tubercles, femora II-IV with 1-13 larger ventral tubercles. Tarsal formula: 5, 9, 7, 8. Penis (Figs 166-167). Median seta larger than two ventro-apical setae and distant from dorsoapical setae; ventralmost basal seta much shorter than other basal setae, 3-4 dorsalmost setae inserted in one oblique row. Ventrally smooth stylus with oblique apex; ventral process flabellum bearing projections on ventral margin. Coloration (Fig. 183). Coxa IV, dorsal scute and free tergites I-II blackish, except for light brown central region from ocularium to free tergite II; all dorsal granules and tubercles of legs, pair of ocularium tubercles and tubercles of lateral margin whitish - remaining tubercles same color as tegument; legs light brown; pedipalps, chelicerae, coxa I, trochanter I, and apophyses on anterior margin of dorsal scute yellowish. Measurements. Dorsal scute: 3-3.7 (3.2) long; 3-3.6 (3) wide; legs: I: 6.9-7.3 (7.3), II: 15.6-17 (17), III: 11.2-12 (12), IV: 15.616.8 (16.8), femur IV: 4.3-5.1 (5.1); pedipalp: 4-4.3 (4.2).

Material examined. Brasil, São Paulo: Santo André (Paranapiacaba, Estação Biológica do Alto da Serra), R. Pintoda-Rocha, C. Firmo \& E. Chaves, IX.1998, 1 ma (MZSP16645, holotype), 1 ma and 2 fe (MZSP16646, paratype); ibidem, R. Pinto da Rocha \& S. Reidel, XII.1999, 2 ma and 2 fe (MNRJ4393, paratype); ibidem, R. Pinto-da-Rocha, C. Firmo \& R. Cordenonsi, V.1998, 1 ma (MZSP16644, paratype); ibidem, R. Pinto-da-Rocha \& S. Casari, I.1997, 1 fe (MZSP 17664); ibidem, R. Pinto-da-Rocha et al., VIII.1999, 2 ma and 2 fe (MZSP 18885); ibidem, R. Pintoda-Rocha, C. Firmo \& R. Cordenonsi, 17.V.1998, 2 fe (MZSP16430). 


\section{Pseudotrogulus mirim Kury, 1992}

Figs 100, 101, 125, 126, 174, 175, 184, 189

Pseudotrogulus mirim Kury, 1992: 286 (figs 14-19, 22-23) [desc]; Firmo \& Pinto-da-Rocha, 2002: 173 [syst]; Kury, 2003: 137 [cat].

Diagnosis. It is similar to $P$. telluris by having a high subanterior margin on dorsal scute, large tubercles on dorsal scute; pair of isolate tubercles on stigmatic area and three large rounded tubercles on free tergites II-III. Differs from P. telluris by having small whitish granules concentrated on posterior margin of dorsal scute; ventral tubercles of femora of legs larger than those on other parts of femora.

Redescription of male and female. Dorsum (Figs 100 and 101). Enlarged tubercles of dorsal scute and free tergites, scattered rounded granules. Anterior margin of dorsal scute with 12 median apophyses smaller than those of corners, or absent (type: 1); 2-4 apophyses on corners (type: 3, external below others). Ocularium high with one pair of enlarged and convergent tubercles, covering entire ocularium roof, same height as ocularium. Prosomal folding of tegument curved inwards, as a sub-anterior margin, placed between ocularium and ozopore, with 5-7 (type: 6/7) large tubercles directed horizontally frontwards. One pair of large tubercles behind ocularium and on mesotergal areas I-III, those of area I more distant from each other, those on area III larger. Granules concentrated in two paramedian regions behind ocularium to area I, near sulcus I, surrounding sulci IIIII, behind and between tubercles of area III, on lateral margin and posterior margin of mesotergum and on free tergites; larger concentration of smaller granules in a stripe on posterior margin and posterior angle of lateral margin. Free tergite I with 0-3 tubercles (type: absent); free tergites II-III with three tubercles; median larger on each segment; median of each anterior free tergite of size similar to paramedian of posterior free tergite; enlarged median on free tergite III. Venter. Smooth stigmatic area, except posterior margin; genital area with only one pair of tubercles at base; genital operculum with few granules at apex. Pedipalps. Tibia IIi/Iili/IIIi (Iili) mesal; Iili ectal. Tarsus IiI mesal; IiI ectal. Legs. Leg I with enlarged tubercles on ventral side of trocanther and on midventro-basal and dorsal areas of femur; femur I with 7-8 ventral tubercles twice as large as dorsal. Trochanter I and coxae II-IV with one high retrolatero-apical tubercle; coxa IV with rounded tubercles and one larger dorso-apical tubercle. Other leg articles with small scattered tubercles; femora II-IV with 3-5 larger ventral tubercles. Tarsal formula: 5, 7/8, 6, 6. Penis (Figs 125 and 126). Apexes of ventral plate slightly directed inwards; median seta slightly larger than two ventroapical setae and far from dorso-apical setae; ventralmost basal seta much shorter than other basal setae, three more dorsal setae in one oblique row inserted in lateral lobe. Stylus apex straight, with ventral projections; ventral process flabellum bearing projections on ventral margin and large long shaft. Coloration (Fig. 184). Brownish-black; smooth region of lateral sides of areas I-II, posterior half of area III and free tergites blackish; main pair of ocularium tubercles, distal part of metatarsi, tarsi, and granules of posterior margin and posterior region of lateral margin of dorsal scute white - tubercles of areas can be slightly whitish in some specimens (type: darker); pedipalps, chelicerae, coxae, trochanter I and apophyses on anterior margin of dorsal scute yellowish. Measurements. Dorsal scute: 3.3-4.3 (4) long; 3-3.9 (3.9) wide; legs: I: 6.4-8 (7.4), II: 15.9-24.4 (22), III: 10.9-16.9 (15.4), IV: 14.722.2 (21), femur IV: 4-7.2 (6.5); pedipalp: 3.2-4.1 (3.9).

Material examined. BrasiL, Rio de Janeiro: Mangaratiba (Reserva Ecológica Rio das Pedras, in front of Club Mediterranée), A. Giupponi, XI.2004, 1 ma and 1 fe (MNRJ17675); Angra dos Reis, W. Bokermann, XI.1991, 1 ma (MZSP11865); Angra dos Reis (road Lídice-Angra, 500 m), A. B. Kury, R. Pinto-da-Rocha, \& L. Mestre, II.1997, 1 ma and 3 fe (MNRJ5537); (Rio São Pedro, tributary of Rio Marambuca), M.B.DaSilva \& H.Y. Yamaguti, XI.2005, 1 ma and 1 fe (MZSP29087); Parati (Parati-Mirim, Road Rio-Santos), A. B. Kury, \& L. A. S. Kury, VI.1989, 2 ma and 1 fe (MNRJ6530, paratypes); (Road Parati to Cunha), M.B.DaSilva \& H.Y. Yamaguti, XI.2005, 7 ma and 5 fe (MZSP22894, 29083, 29084, 29088, 29089); São Paulo: Ubatuba (Picinguaba, Morro do Cuscuzeiro), G. Machado, XII.1995, 1 fe (MZSP16314); Ubatuba (Parque Estadual da Ilha de Anchieta, Fazenda Angelin), Equipe Biota, VIII.2001, 1 fe (IBSP3355); Ilhabela, Equipe Biota, X.2001, 2 fe (IBSP3746); Ilhabela (Trilha da Figueira), R. J. Sawaia, V.1997, 1 ma (MZSP16856); Salesópolis (Estação Biológica de Boracéa), R. Pintoda-Rocha, S. Casari, M. Ramirez \& R. S. Bérnils, I.1999, 1 ma (MZSP21665); ibidem, R. Pinto-da-Rocha et al., V.2001, 1 ma and 2 fe (MZSP29095); ibidem, A. D. Brescovit et al., IX.2000, 1 ma (IBSP1718); ibidem, C. Yamamoto, 1-4.VI.1997, 1 fe (MZSP22168); ibidem, J. P. L. Guadanucci, VI.2003, 1 ma (MZSP22073).

\section{Pseudotrogulus telluris Roewer, 1932}

Figs 102-104, 170-173, 189

Pseudotrogulus telluris Roewer, 1932: 309 (fig. 25) [desc]; MelloLeitão, 1935: 97 [cit]; Soares \& Soares, 1948: 615 [cat]; Kury, 1992: 285 [syst]; Firmo \& Pinto-da-Rocha, 2002: 173 [syst]; Kury, 2003: 137 [cat].

Diagnosis. It is closely related to $P$. mirim by having a strong folding of tegument on prosoma, as sub-anterior margin, high tubercles on dorsal scute, a pair of tubercles isolated on stigmatic area and three large, rounded tubercles on free tergites IIIII. P. telluris differs from P. mirim mainly by having granules distant from each other, on posterior margin of dorsal scute, by lacking larger tubercles on venter of femora II-IV and by presenting a whitish pair of tubercles on mesotergal area III.

Redescription of male and female. Dorsum (Figs 102 and 103). Large and rounded tubercles on dorsal scute and free tergites. Anterior margin of dorsal scute with one or two median apophyses smaller than those of corners or absent (type: 2); two or three apophyses on corners (type: 3 , same row). High ocularium with one pair of high convergent tubercles covering entire ocularium roof, same height as ocularium. Prosomal folding of tegument curved inwards, placed between ocularium and ozopore, 


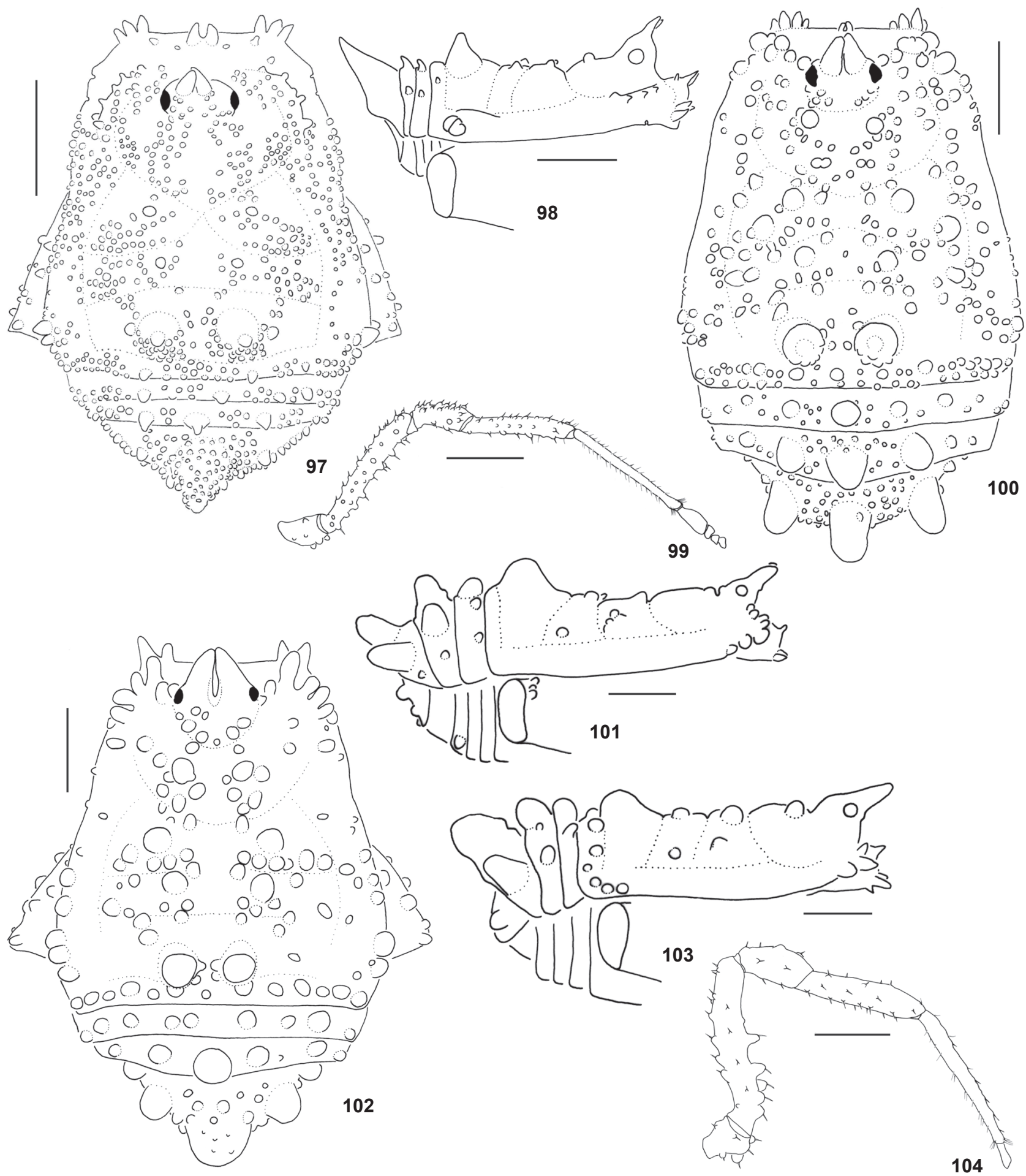

Figures 97-104. (97-99) Pseudotrogulus funebris: (97) dorsal habitus (MZSP18885); (98) body, right lateral view, male holotype (MZSP16645); (99) trochanter-tarsus of right leg I, retrolateral view (MZSP21666). (100-101) Pseudotrogulus mirim, female (MZSP16314): (100) dorsal habitus; (101) right lateral view. (102-104) Pseudotrogulus telluris: (102) dorsal habitus (male, MNRJ4595); (103) body, right lateral view, female (IBSP2269); (104) trochanter-tarsus of right leg I, retrolateral view, male holotype (SMFD1406). Scale bar: 1 mm. 
formed by five or six large cylindrical frontward directed tubercles. One pair of tubercles behind ocularium and on areas I-III; distant from each other in area I; larger in III. Granules concentrated in two paramedian regions behind ocularium to area I, near sulcus I, surrounding sulci II-III, behind and between tubercles of area III, on lateral margin and posterior margin of mesotergum, and free tergites. Free tergites II-III with three tubercles, median larger, and largest in III. Venter. Smooth stigmatic area, except for posterior margin, genital area with only one pair of tubercles at base; genital operculum with a few granules at apex. Pedipalps. Tibia IIi/IiIi (Iili) mesal and ectal. Tarsus II mesal, IiI ectal. Legs (Fig. 104). Trochanter I with high ventral tubercles; femur I with high tubercles on entire dorsum, with six ventral tubercles, twice larger than dorsal tubercles. Trochanter I and coxae II-IV with one retrolatero-apical high tubercle; coxa IV with rounded tubercles, larger dorso-apically. Remaining areas of legs with small, scattered and uniformly distributed tubercles. Tarsal formula: 5, 7/9 (8), 6, 6/7 (6). Penis (Figs 170-173). Apexes of ventral plate slightly directed inwards; median seta similar in size to two ventro-apical setae and distant from dorso-apical setae; basal ventralmost seta much shorter than other basal setae, dorsalmost more apicad, other three setae in one horizontal row on lateral lobe. Stylus with straight apex and ventral projections; ventral process flabellum bearing projections on ventral margin with strong and long shaft. Coloration. Dark reddish-brown, with smooth region of areas of dorsal scute blackish; all tubercles of femora, of area III, main pair of ocularium and apex of metatarsi and tarsi whitish in some specimens, the pair of area I tubercles are also whitish (type: brown); pedipalps, chelicerae, coxa-trochanter I and apophyses on anterior margin of dorsal scute yellowish. Measurements. Dorsal scute: 4.1-4.6 (4.4) long; 3.5-5 (5) wide; legs: I: 7.37.7 (7.7), II: 21.3-25.3 (25.3), III: 14.3-16.3 (16), IV: 19.1-22.2 (22.2), femur IV: 5.8-7.2 (7.2); pedipalp: 4.1-4.2 (4.2).

Material examined. BRASIL: Caldeirão, Rio Madeira (mislabeled?), 1 fe (SMFD1406, holotype). Rio de Janeiro: Teresópolis, R.S.B. Bérnils, 1 fe (MZSP27685); (Faz. Vale da Revolta), R. L. C. Baptista, I.1995, 1 ma (MNRJ4595); Teresópolis (Parque Nacional da Serra dos Órgãos), Equipe Biota, VIII.2001, 1 ma and 1 fe (IBSP2269); ibidem, R. Pinto-da-Rocha, B. Dietz \& R. Rosa, XI.1999, 1 fe (MZSP29061); Rio de Janeiro (Parque Estadual da Pedra Branca, Pau da Fome), A. Giupponi, D. Pedroso \& A.C. Gonçalves, VIII.2004, 1 fe (MNRJ17630).

\section{Pseudotrogulus pagu sp. nov.}

Figs 105-108, 117, 127, 128, 189

Diagnosis. It is the smallest species of Hernandariinae, similar in size to Pseudotrogulus trotskyi sp. nov. It also shares high and convergent median apophyses on anterior margin of dorsal scute, as well as those of corners with Pseudotrogulus trotskyi sp. nov.. Differs from other species of Pseudotrogulus by having an almost smooth lateral margin of dorsal scute and high, conical and parallel tubercles on ocularium. Differs from Pseudotrogulus trotskyi sp. nov. by having a heterogeneous less densely granu- lated body and conical tubercles on mesotergal area III, posterior margin, and free tergites.

Description of male and female. Dorsum (Figs 105 and 107). Anterior margin of dorsal scute with one pair of convergent median apophyses; 2-3 (type: 2/3) apophyses on corners, ectalmost ventral. Ocularium high, with one pair of large parallel tubercles, covering ocularium roof, same height than ocularium. Prosomal folding of tegument, as sub-anterior margin, curved inwards, between ocularium and ozopore, distant from lateral margin; with three or four (type: 4) conical tubercles. Prosoma behind ocularium and mesotergal areas I-III with one main pair of tubercles (apart on area II and prosoma); III with one pair of conical tubercles, I-II with one pair of similar sized paramedian tubercles. Scattered granulation, concentrated near sulci of areas, on prosoma behind ocularium, on posterior margin of dorsal scute and free tergites. Smooth lateral margin of dorsal scute, except for 3-5 (type: 4) tubercles near areas II-III. Posterior margin of dorsal scute and free tergite I with one pair, II with two or three (type: 3), and III with three larger conical tubercles, median tubercles of free tergites II-III larger. Venter. Uniformly distributed granules, similar in size to those of dorsal scute, in row on free sternites and coxae, except proximal smooth region; genital and stigmatic areas with lower density of granules, with one pair of tubercles at base of genital area; genital operculum with few granules at apex. Pedipalps (Fig. 117). Tibia IIi/IiIi (type: IiIi) mesal; II ectal. Tarsus IiI mesal; IiI ectal. Legs (Figs 106 and 108). I with strong tubercles on venter of trochanter; middle basal ventral and dorsum of femur; femur I with 5-6 (type: 5 ) ventral tubercles twice larger than dorsal; femora II-IV with 2 9 (type: 6, 3, 5, respectively) larger ventral tubercles. Other leg articles with small scattered tubercles. Tarsal formula: 4/5 (5), 7/ 9 (9), 6/7 (7), 6/8 (8). Penis (Figs 127-128). Median seta slightly larger than two ventro-apical setae and distant from dorso-apical setae; ventralmost basal seta much shorter than other basal setae, three other basal setae in one oblique row inserted in lateral lobe. Ventrally smooth stylus with straight apex; ventral process flabellum bearing projections on ventral margin. Coloration. Uniformly light brown; pedipalps and chelicerae yellowish; ventral femora and lateral margin of dorsal scute tubercles whitish. Measurements. Dorsal scute: 2.2-2.4 (2.3) long; 2-2.4 (2.2) wide; legs: I: 4-4.6 (4.6), II: 7.8-8.4 (7.9), III: 5.7-6.4 (5.9), IV: 8-8.7 (8.1), femur IV: 2.1-2.3 (2.1); pedipalp: 2.5-2.7 (2.6).

Material examined. Brasil, São Paulo: Cotia (Reserva do Morro Grande, Quilombo), M. C. Silveira, III.2003, 1 ma and 1 fe (MZSP28164, holotype ma and paratype fe); ibidem, J. P. Guadanucci, XII.2002, 1 fe (MZSP25767, paratype); Cotia (Reserva do Morro Grande, Grilos), G. R. S. Ruiz, III.2003, 1 ma (MZSP25768, paratype); Cotia (Reserva do Morro Grande, Torres), G. R. S. Ruiz, III.2003, 1 ma and 1 fe (MZSP25769, paratypes).

Etymology. A substantive in apposition of Patrícia Galvão, nickname "Pagu" (1910-1962), who was a socialist playwright and modernist writer. She was born and lived in São Paulo state, where she was a feminist symbol and organized worker's struggle. 

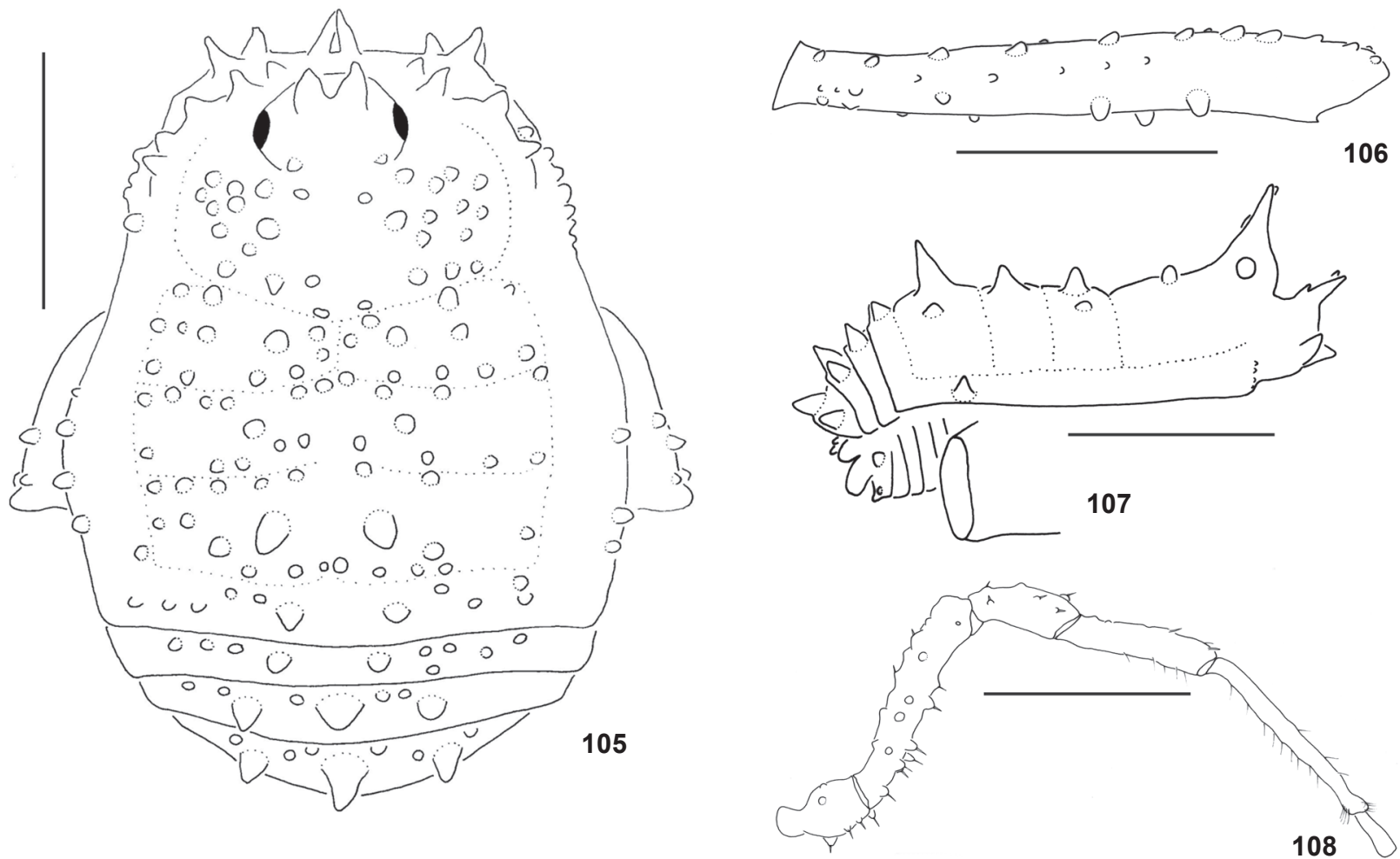

Figures 105-108. Pseudotrogulus pagu sp. nov.: (105) dorsal habitus, male holotype (MZSP25097); (106) right femur IV, prolateral view, female (MZSP25097); (107) body, right lateral view (MZSP25768); (108) trochanter-tarsus of right leg I, retrolateral view, female (IBSP). Scale bar: $1 \mathrm{~mm}$.

\section{Pseudotrogulus trotskyi sp. nov.}

Figs 109-111, 129, 130, 189

Diagnosis. It is as small as Pseudotrogulus pagu sp. nov., but presents longer legs. It differs from other species of Pseudotrogulus by having the anterior margin of dorsal scute covered by tubercles in same row of median and lateral apophyses; ocularium with low tubercles; body covered with dense granulation; whitish tubercles on dorsal scute and free tergites (granules are same color as tegument); four mesotergal areas, and the smallest number of tarsomeres amongst Hernandariinae $(3,5,5,5)$.

Male description. Dorsum (Figs 109 and 110). Anterior margin of dorsal scute with one pair of median, high, convergent apophyses; three high apophyses on corners, two dorsal parallel and similar-sized, third ventral and smaller; 3-4 high tubercles between pairs of apophyses, covering entire margin. Ocularium low, slightly larger than eye height, with one pair of small tubercles distant from each other and similar to other prosomal tubercles. Prosoma with some scattered tubercles, concentrated at median region behind ocularium. Four mesotergal areas; areas I-III of similar size, area IV with half the length of anterior areas; I-III with one pair of main tubercles, some smaller rounded and scattered; tubercles distant from each other on I, closer on area II; I-II with similar-sized tubercles, III larger; IV with two pairs of smaller tubercles in a horizontal row. Dense granulation covering entire dorsal scute. Lateral margin almost smooth, with two small tubercles near area II. Posterior margin of dorsal scute and free tergites with one row of rounded tubercles, two larger. Venter. Coxae, free sternites, and center of stigmatic and genital areas densely covered with strong granules; genital operculum with small granules. Pedipalps. Tibia IiIi mesal, IiI ectal. Tarsus IiI mesal, IiI ectal. Legs (Fig. 111). Leg I with strong tubercles on venter of trochanter and on ventro-proximal $2 / 3$, medium-lateral region, and dorsal part of femur; femur I with six extremely high ventral tubercles. Coxa IV with one high retrolateral apical tubercle and three high external and rounded dorso-apical tubercles; trochanter IV with one retrolateral basal tubercle. Remaining leg articles with small scattered tubercles, femur II with four ventral tubercles and three prolateral, femur III with 2-3 ventral and two prolateral and femur IV with three larger ventral tubercles. Tarsal formula: 3, 5, 5, 5. Penis (Figs 129 and 130). Median seta almost half the size of dorsal-apical setae; ventralmost basal seta much shorter than other basal setae, three dorsal setae in oblique row inserted in lateral lobe. Stylus 

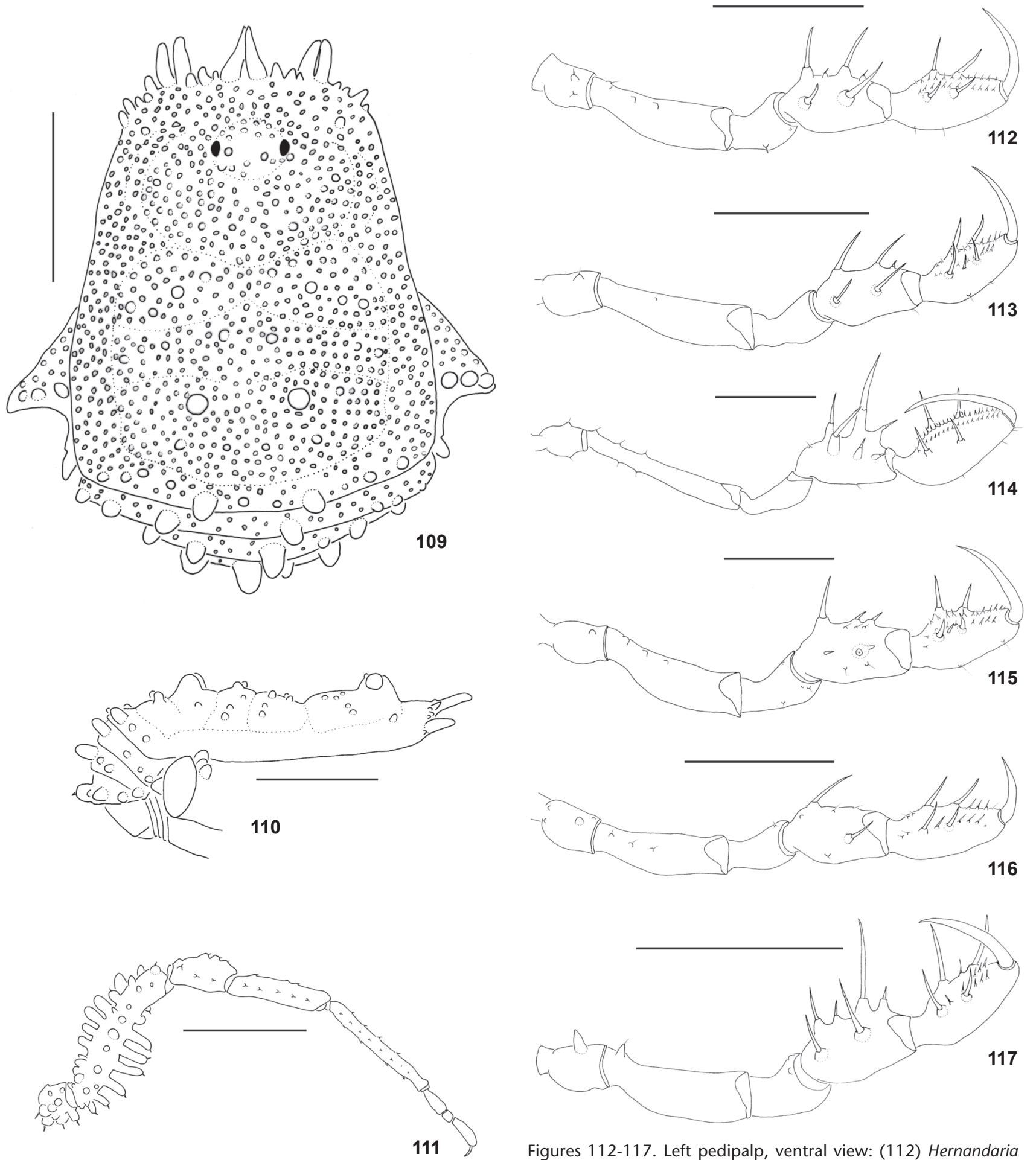

Figures 112-117. Left pedipalp, ventral view: (112) Hernandaria heloisae; (113) Hernandaria anitagaribaldiae sp. nov.; (114)

Figures 109-111. Pseudotrogulus trotskyi sp. nov.: (109) dorsal habitus (MZSP); (110) body, prolateral view (MZSP); (111) trochantertarsus of right leg I, retrolateral view (MZSP). Scale bar: $1 \mathrm{~mm}$.

Acrogonyleptes granulatus; (115) Acrogonyleptes spinifrons; (116) Acrogonyleptes cheguevarai sp. nov.; (117) Pseudotrogulus pagu sp. nov. Scale bar: $1 \mathrm{~mm}$. 

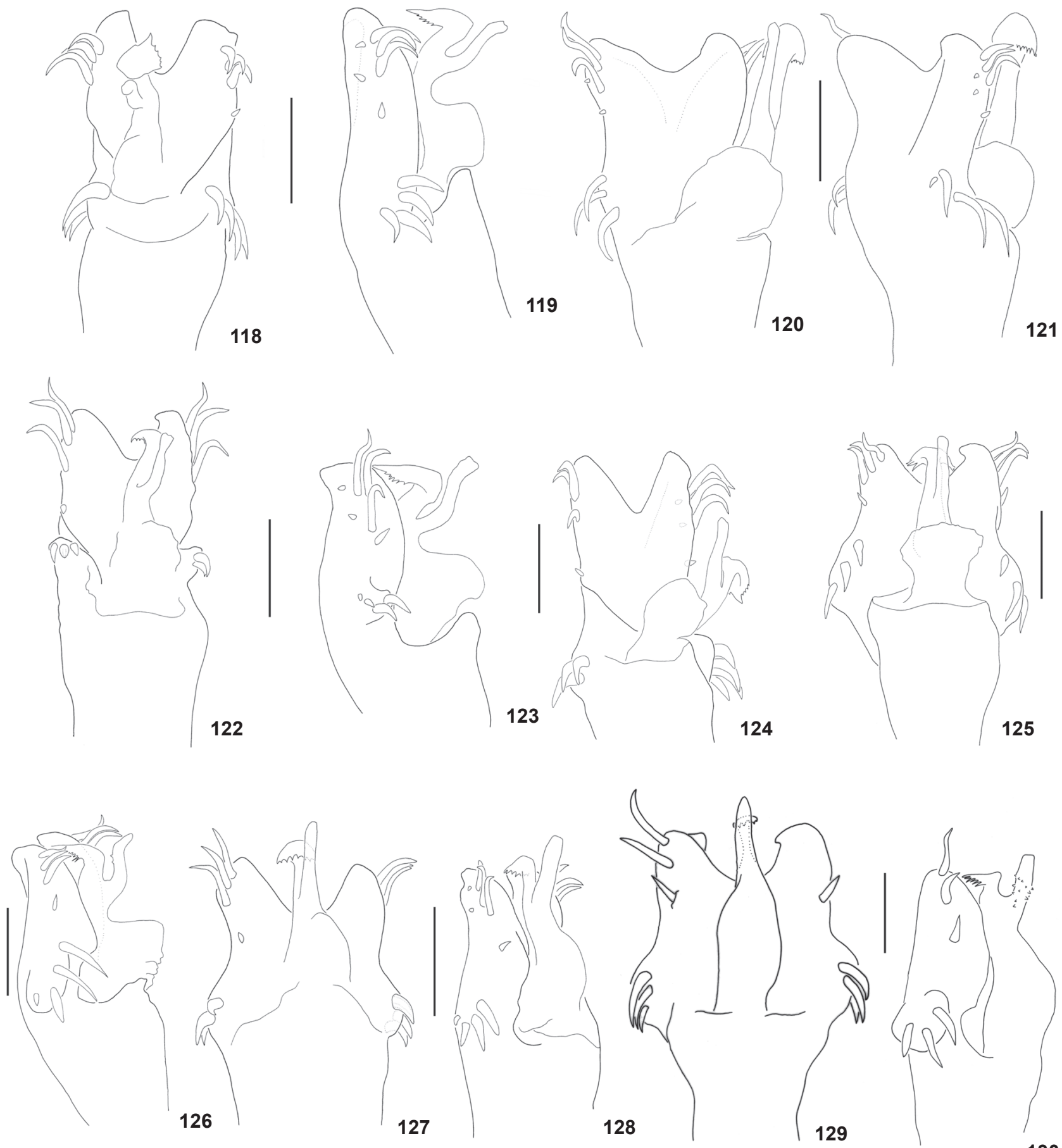

Figures 118-130. Penis: (118-119) Hernandaria setulosa, paralectotype (MNRJ26924); (120-121) H. chicomendesi sp. nov., holotype (MNRJ14313); (118 and 120) dorsal view; (119 and 121) left lateral view; (122-123) H. anitagaribaldiae sp. nov., paratype (IBSP5854): (122) dorsal view, (123) left lateral view; (124) H. sundermannorum sp. nov., holotype, dorsal view (MNRJ17114); (125-126) Pseudotrogulus mirim (MZSP): (125) dorsal view, (126) left lateral view; (127-128) P. pagu sp. nov. (MZSP25768): (127) dorsal view, (128) left lateral view; (129-130) Pseudotrogulus trotskyi sp. nov., holotype (MZSP28165): (129) dorsal view, (130) left lateral view. Scale bar: (118-128) $0.075 \mathrm{~mm},(129-130) 0.05 \mathrm{~mm}$. 

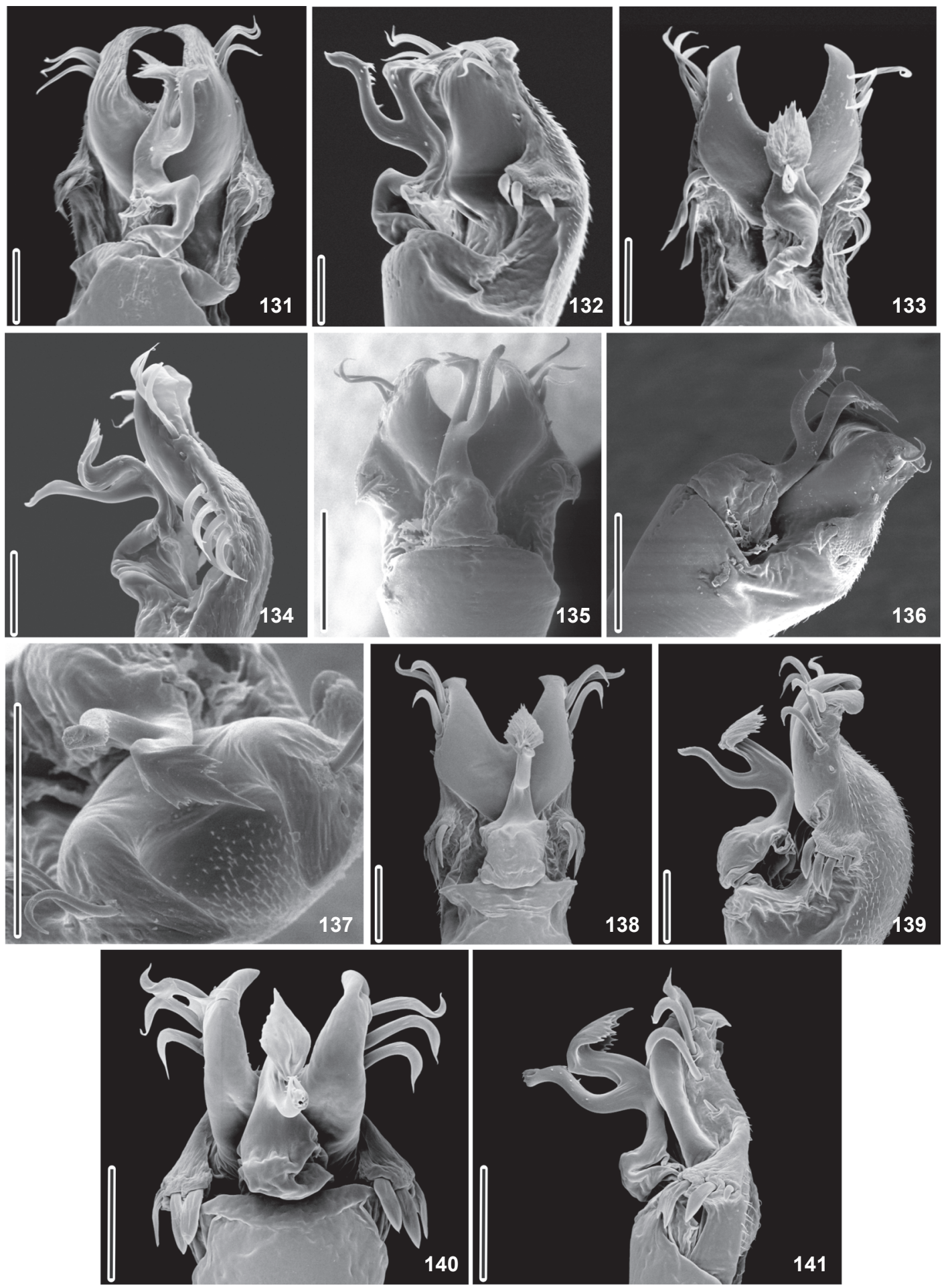

Figures 131-141. Penis: (131-132) Hernandaria armatifrons (MZSP15954): (131) dorsal view, (132) right lateral view; (133-134) Hernandaria heloisae (MZSP1338): (133) dorsal view, (134) right lateral view; (135-137) Hernandaria scabricula (MNRJ1415): (135) dorsal view; (136) right lateral view; ( 137) apical view; (138-139) Hernandaria una (MZSP18668): (138) dorsal view, (139) right lateral view; (140141) Hernandaria zumbii sp. nov. (MZSP18660): (140) dorsal view, (141) right lateral view. Scale bars: $0.05 \mathrm{~mm}$. 

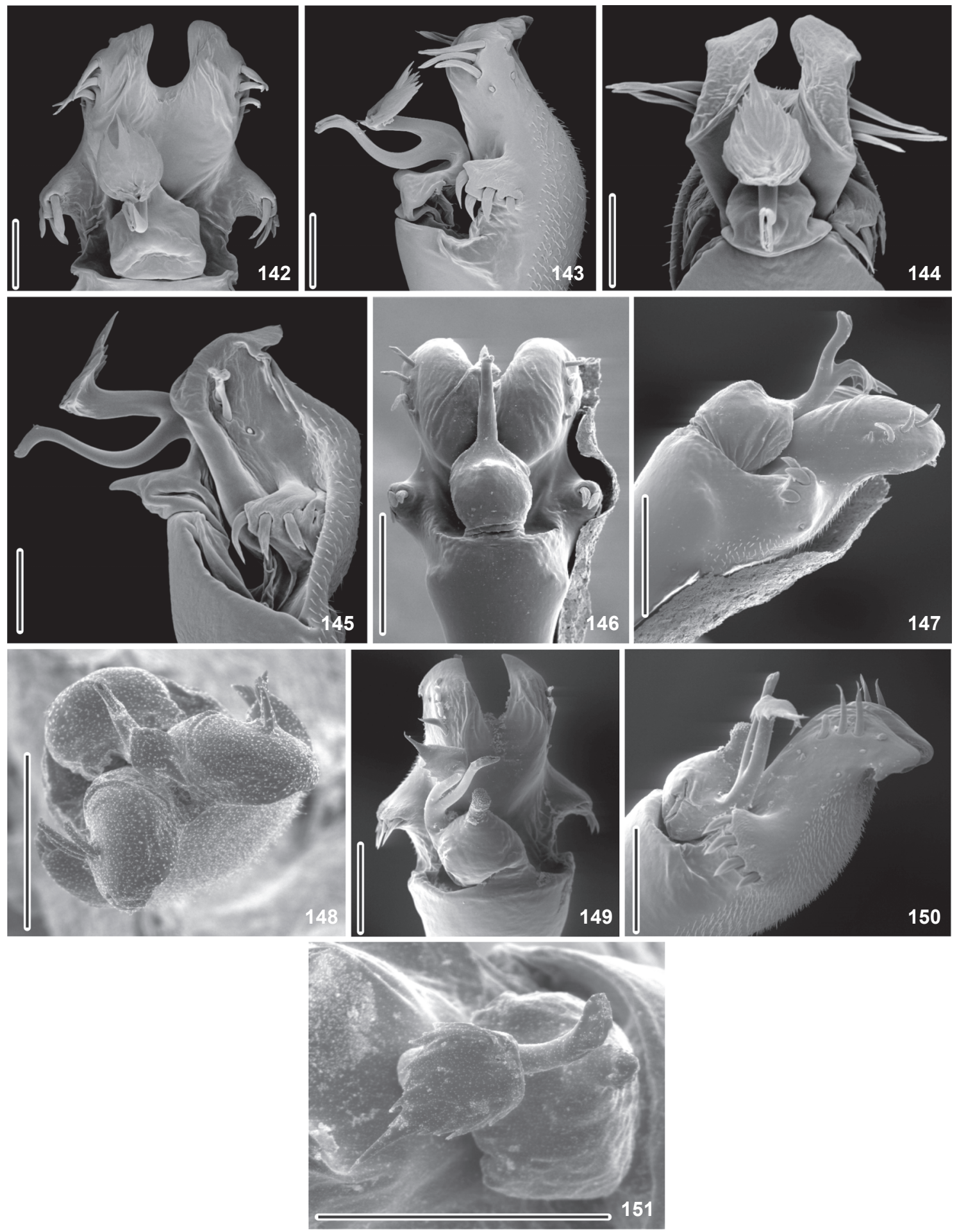

Figures 142-151. Penis: (142-143) Acrogonyleptes exochus (MZSP18679): (142) dorsal view, (143) right lateral view; (144-145) Acrogonyleptes rhinoceros (MZSP18653): (144) dorsal view, (145) right lateral view; (146-148) Acrogonyleptes granulatus: (146) dorsal view (MCN1352); (147) right lateral view (MCN1352); (148) apical view (MCN228); (149-151) Acrogonyleptes pectinifemur: (149) dorsal view (MNRJ4961); (150) right lateral view (MNRJ4961); (151) apical view of glans (HSCP265). Scale bars: $0.05 \mathrm{~mm}$. 

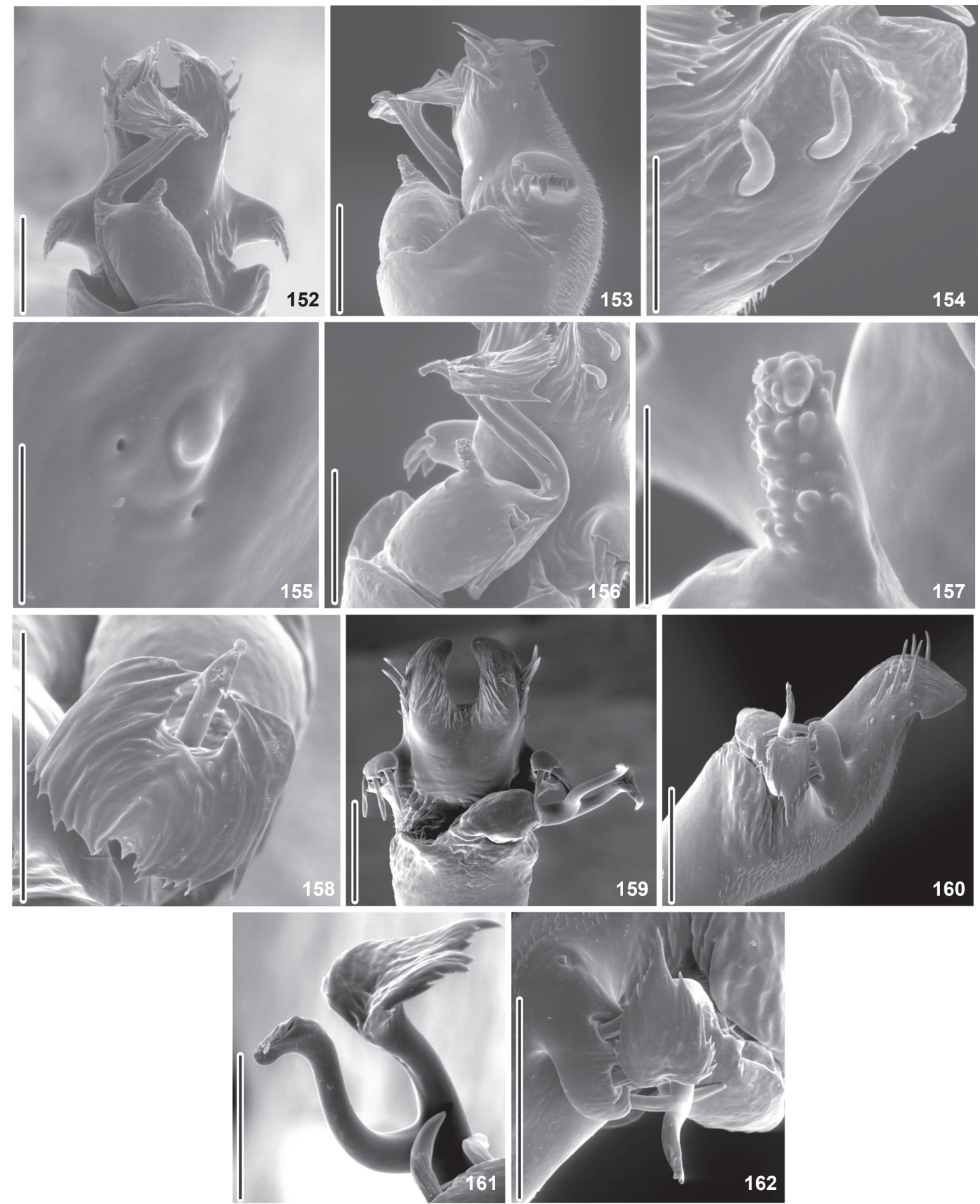

Figures 152-162. Penis: (152-158) Acrogonyleptes spinifrons (MCN595): (152) dorsal view; (153) right lateral view; (154) detail of apical setae; (155) detail of basalmost of apical setae; (156) right dorso lateral view of glans; (157) dorsal process; (158) apical view of ventral process and stylus; (159-162) Acrogonyleptes cheguevarai sp. nov. (MCP): (159) dorsal view; (160) right lateral view; (161) right lateral view of ventral process and stylus; (162) apical view of ventral process and stylus. Scale bars: (152-153) $0.05 \mathrm{~mm},(154,162) 0.025 \mathrm{~mm}$, (155) $0.005 \mathrm{~mm},(156,158-161) 0.05 \mathrm{~mm}$, (157) $0.0125 \mathrm{~mm}$. 

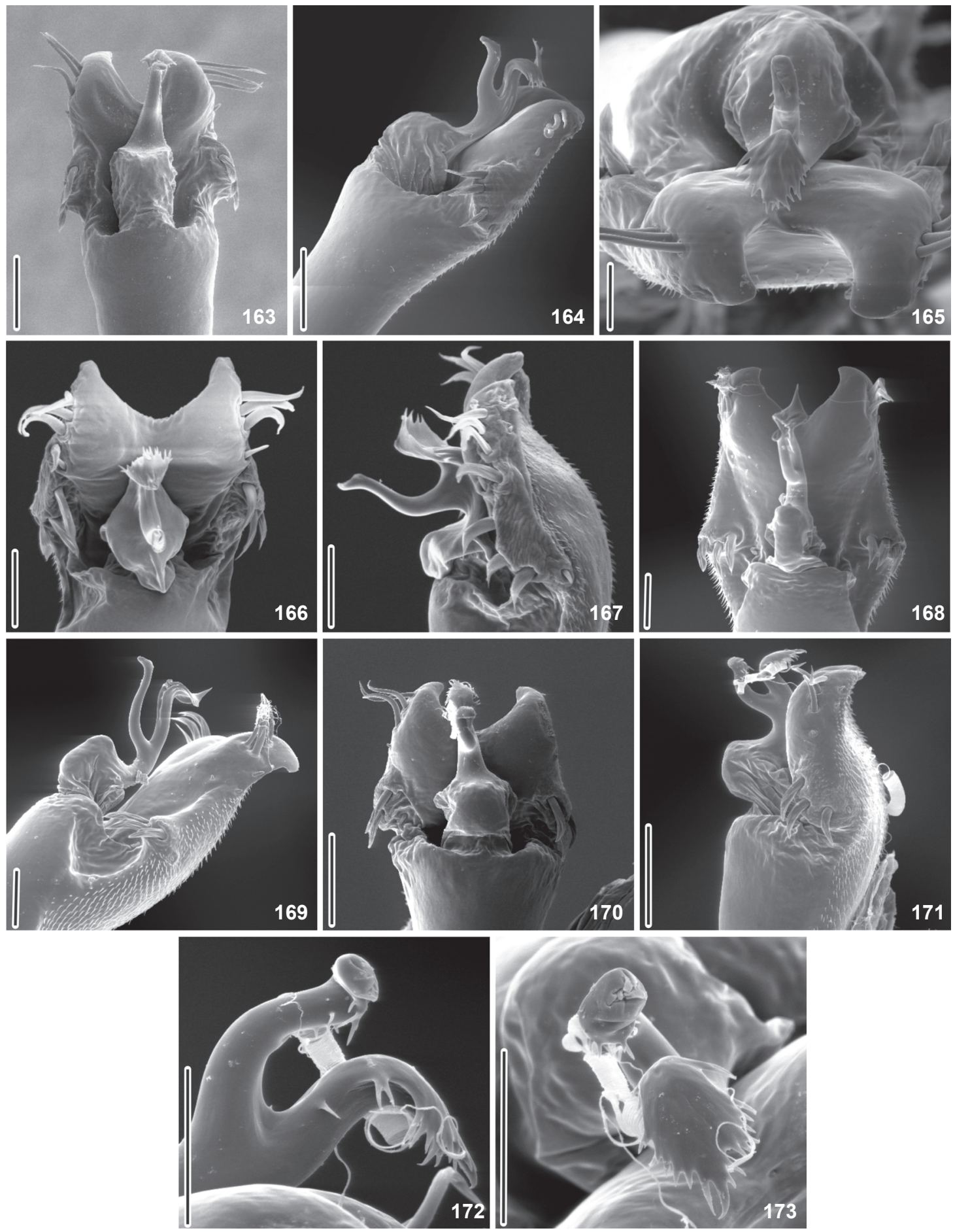

Figures 163-173. Penis: (163-165) Piassagera brieni (MZSP17613): (163) dorsal view; (164) left lateral view; (165) apical view; (166167) Pseudotrogulus funebris (MZSP21666): (166) dorsal view, (167) right lateral view; (168-169) Multumbo terrenus (MZSP15493); (168) dorsal view, (169) right lateral view; (170-173) Pseudotrogulus telluris (MNRJ4595): (170) dorsal view; (171) right lateral view; (172) right lateral view of ventral process and stylus; (173) apical view of ventral process and stylus. Scale bars: $(163-164,166-171) 0.05$ $\mathrm{mm},(165) 0.03 \mathrm{~mm},(172-173) 0.025 \mathrm{~mm}$. 

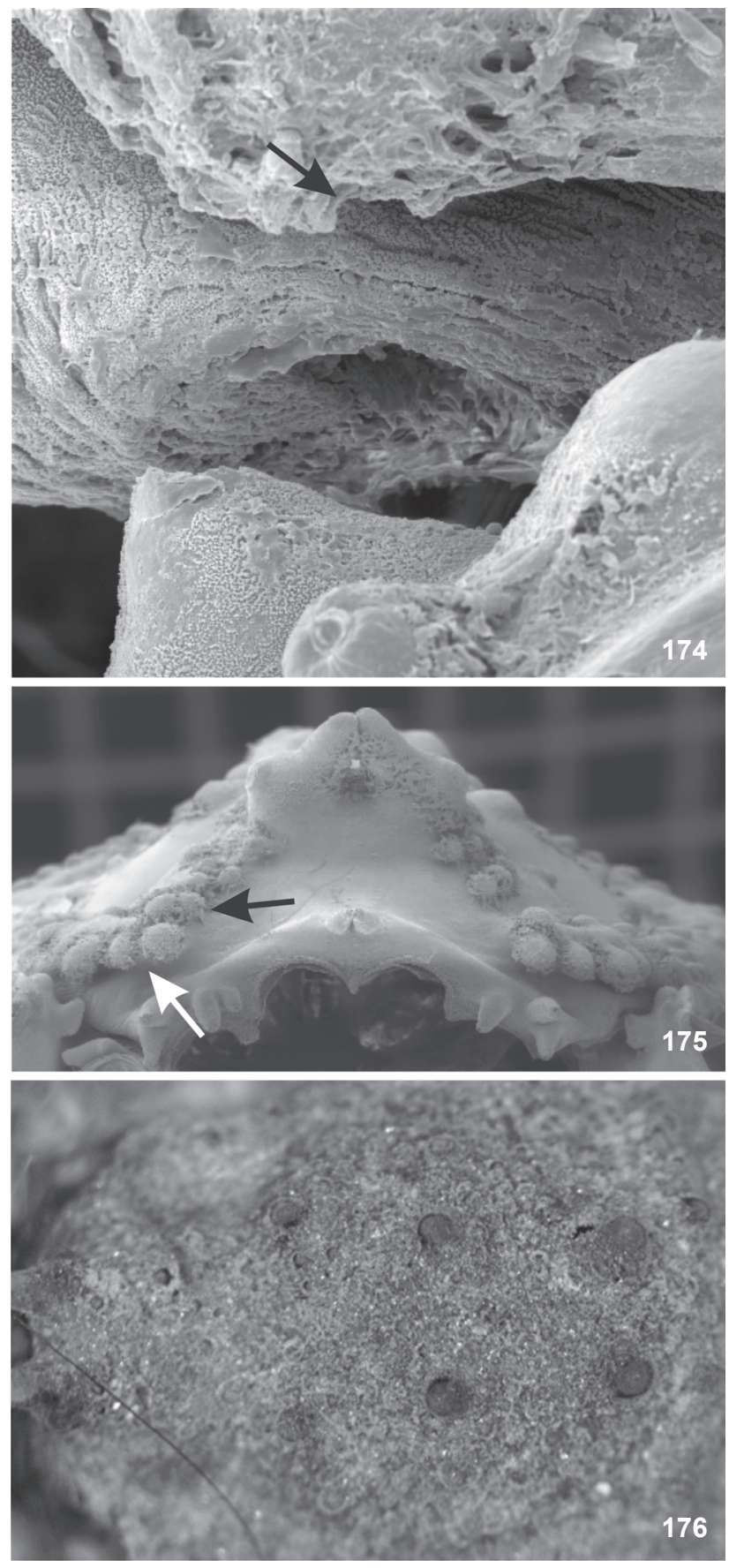

Figures 174-176. (174) Left ozopore of Pseudotrogulus mirim, lateral view: (175) folding of sub-anterior region of prosoma of $P$. mirim with enlarged tubercles arrowed, frontal view; (176) tegument of dorsal scute of Multumbo terrenus covered with debris, dorsal view. with straight apex and small subapical projections; ventral process with flabellum bearing projections on ventral margin. Coloration. Brown; lateral of prosoma, mesotergal areas I-IV, and free tergites blackish; all body tubercles and larger tubercles of legs whitish; trochanters, apophyses on anterior margin of dorsal scute, pedipalps and behind ocularium yellowish. Measurements. Dorsal scute: 2.6 long; 2.1 wide; legs: I: 4.25, II: 10.3, III: 7.9, IV: 10.8, femur IV: 3.0; pedipalp: 2.4 .

Material examined. BrasiL, Paraná: Guaraqueçaba (PR-405, Road to Curitiba), M.B. DaSilva et al., XII.2005, $1 \mathrm{ma}$ (MZSP28265, holotype).

Etymology. In honor of Leon Trotsky (1879-1940), one of the Russian socialist revolution leaders, who definitively changed $20^{\text {th }}$ century history. He was killed by order of Josef Stalin who transformed the Soviet Union into a dictatorial bureaucracy.

\section{Systematic notes on Gonyleptinae}

The synonymy of the type species of the genus Sphaerobunus Roewer 1917 (hitherto in the Gonyleptinae) with the hernandarienean Acrogonyleptes Roewer 1917 obligates the resurrection of the genus Acanthogonyleptes Mello-Leitão, 1922 (type species: Acanthogonyleptes pulcher Mello-Leitão 1922). Acanthogonyleptes has an extensive listing of 14 generic junior synonyms (KuRY 2003) which resulted in the following new combinations herein proposed:

Acanthogonyleptes alticola (Mello-Leitão, 1922) comb. nov. Acanthogonyleptes editus (Roewer, 1943) comb. nov.

Acanthogonyleptes fallax (Mello-Leitão, 1932) comb. nov. Acanthogonyleptes fulvigranulatus (Mello-Leitão, 1922) comb. nov. Acanthogonyleptes marmoratus (Mello-Leitão, 1940) comb. nov. Acanthogonyleptes pictus (Piza, 1942) comb. nov.

Acanthogonyleptes singularis (Mello-Leitão, 1935) comb. nov. Acanthogonyleptes soaresi (Mello-Leitão, 1944) comb. nov. Acanthogonyleptes variolosus (Mello-Leitão, 1944) comb. nov.

\section{Geographical distribution (Figs 185-189)}

Hernandariinae lives in the main core of the Atlantic Rain Forest, from the states of Rio de Janeiro to Rio Grande do Sul, except one species, Hernandaria scabricula, which lives to the south in inland Atlantic Forest and in riparian forests alongside the Prata River basin (Argentina and Paraguay). Of the 22 species of this subfamily, 19 live in ombrophilous forest close to the coast, while $H$. armatifrons lives exclusively in Araucaria forests and Acrogonyleptes spinifrons lives from the coastal area to the inland forest.

PinTO-DA-Rocha et al. (2005) studied four subfamilies of harvestmen (Goniosomatinae, Caelopyginae, Sodreaninae, and Progonyleptoidellinae) to present a historical biogeographic hypothesis of biota diversification in the Atlantic Rain Forest. They showed a high degree of endemism in harvestmen by using a similarity analysis among several well-sampled localities and pointed out the big role of geomorphological history 

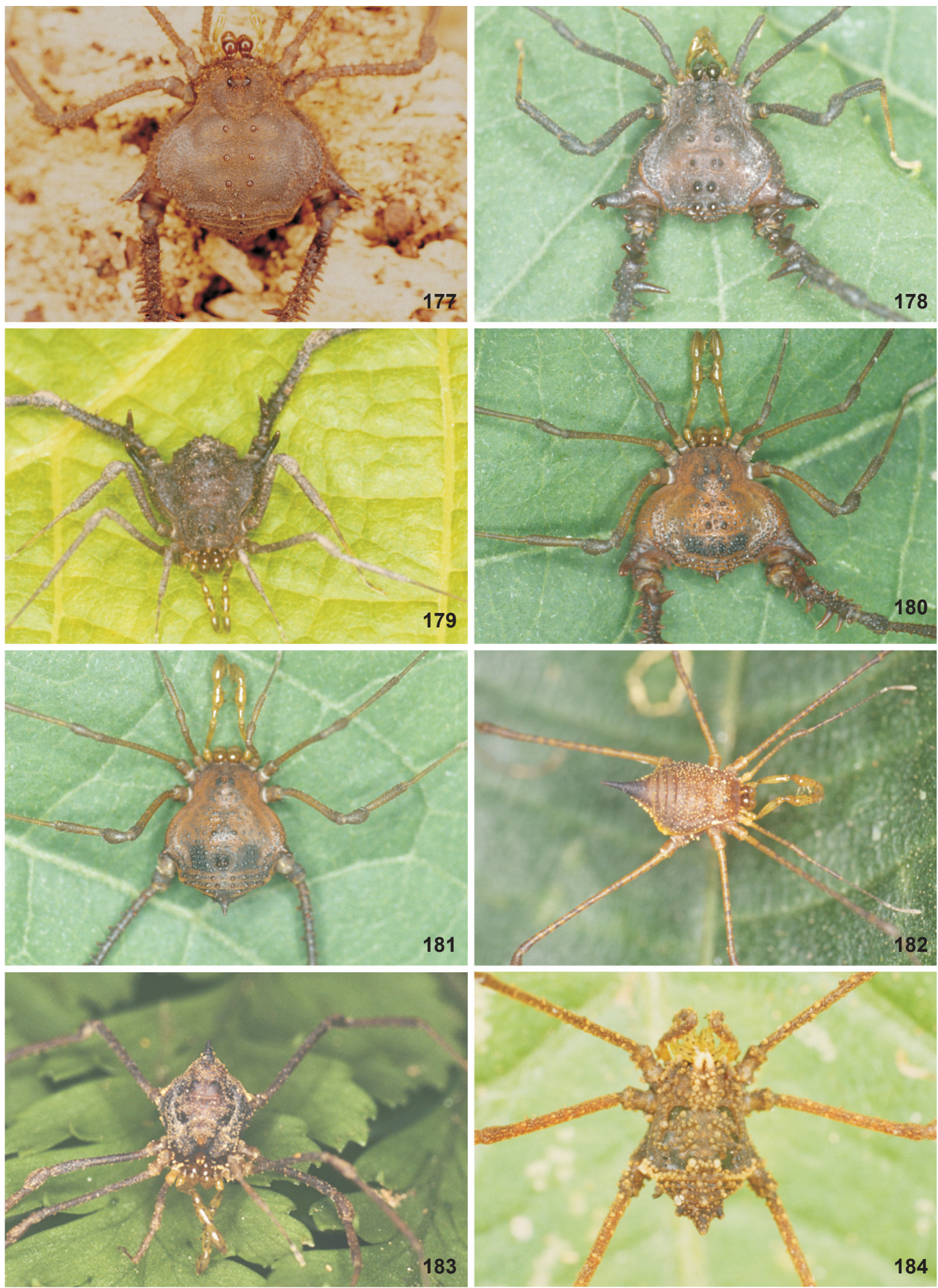

Figures 177-184. Photographs of live specimens of Hernandariinae: (177) Hernandaria armatifrons, male; (178) H. una, male; (179) H. anitagaribaldiae sp. nov., male; (180) Acrogonyleptes exochus, male; (181) A. exochus, female; (182) Piassagera brieni ; (183) Pseudotrogulus funebris; (184) Pseudotrogulus mirim. 

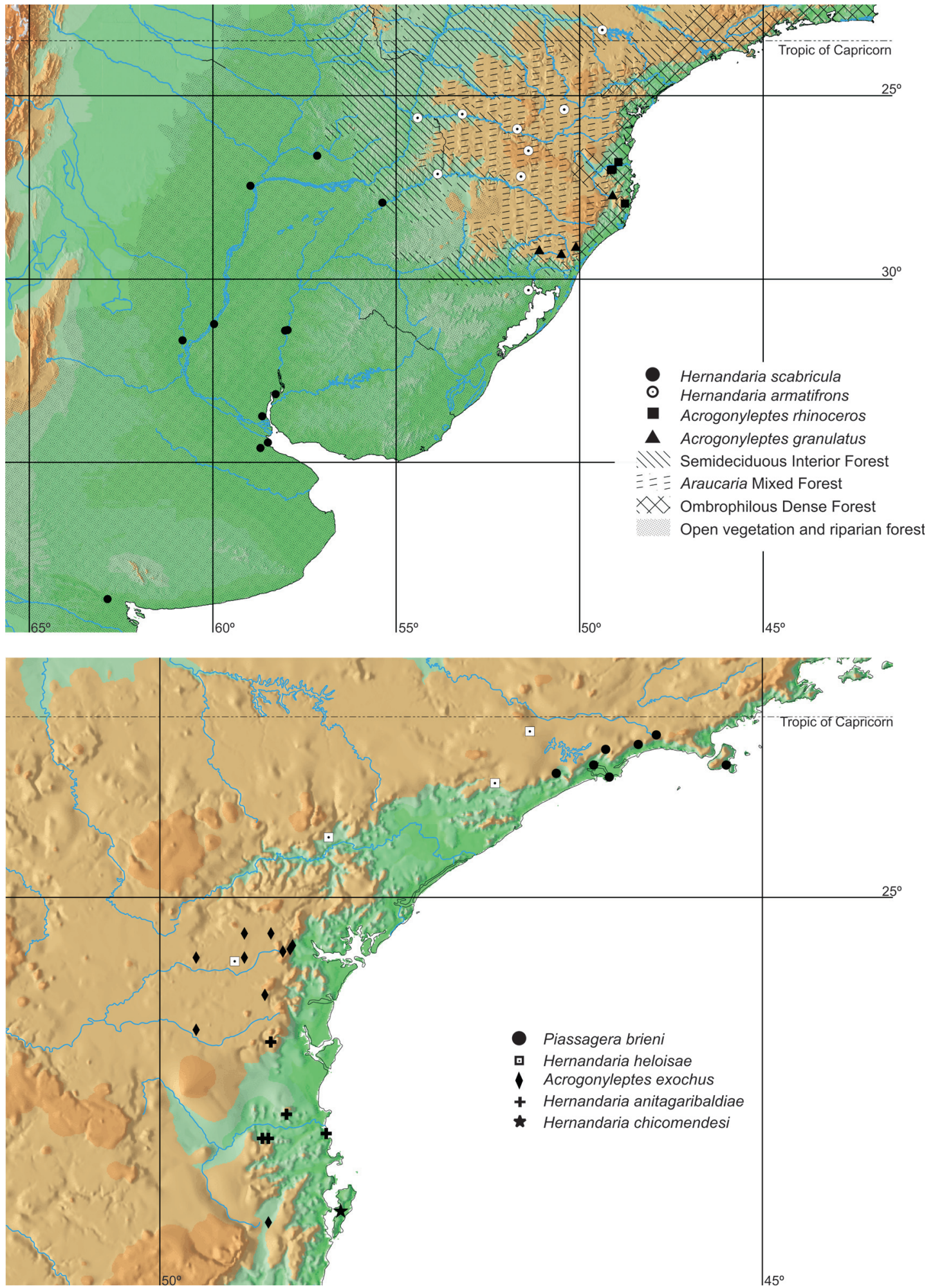

Figures 185-186. Records of geographical distribution of Hernandariinae. 

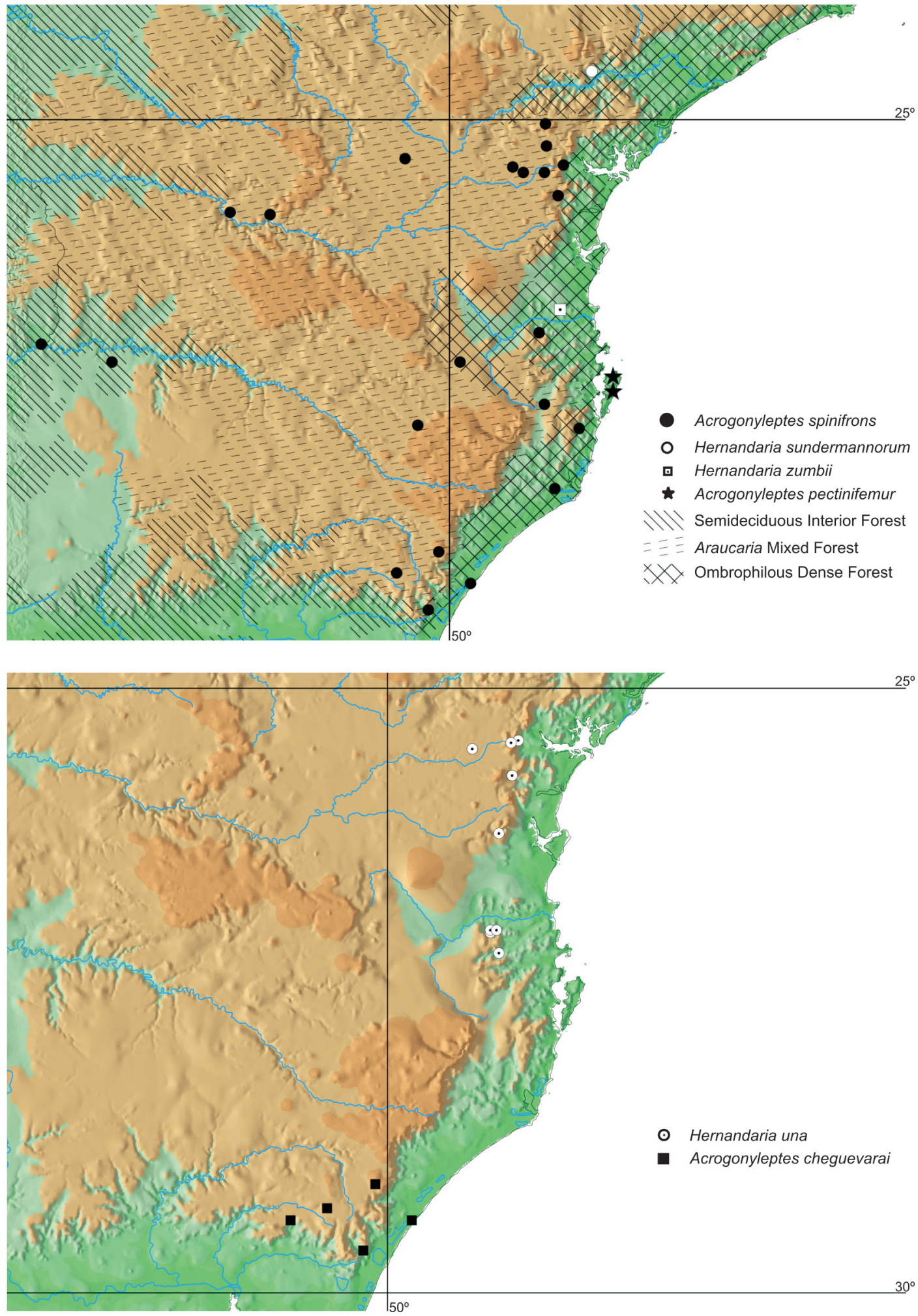

Figures 187-188. Records of geographical distribution of Hernandariinae. 


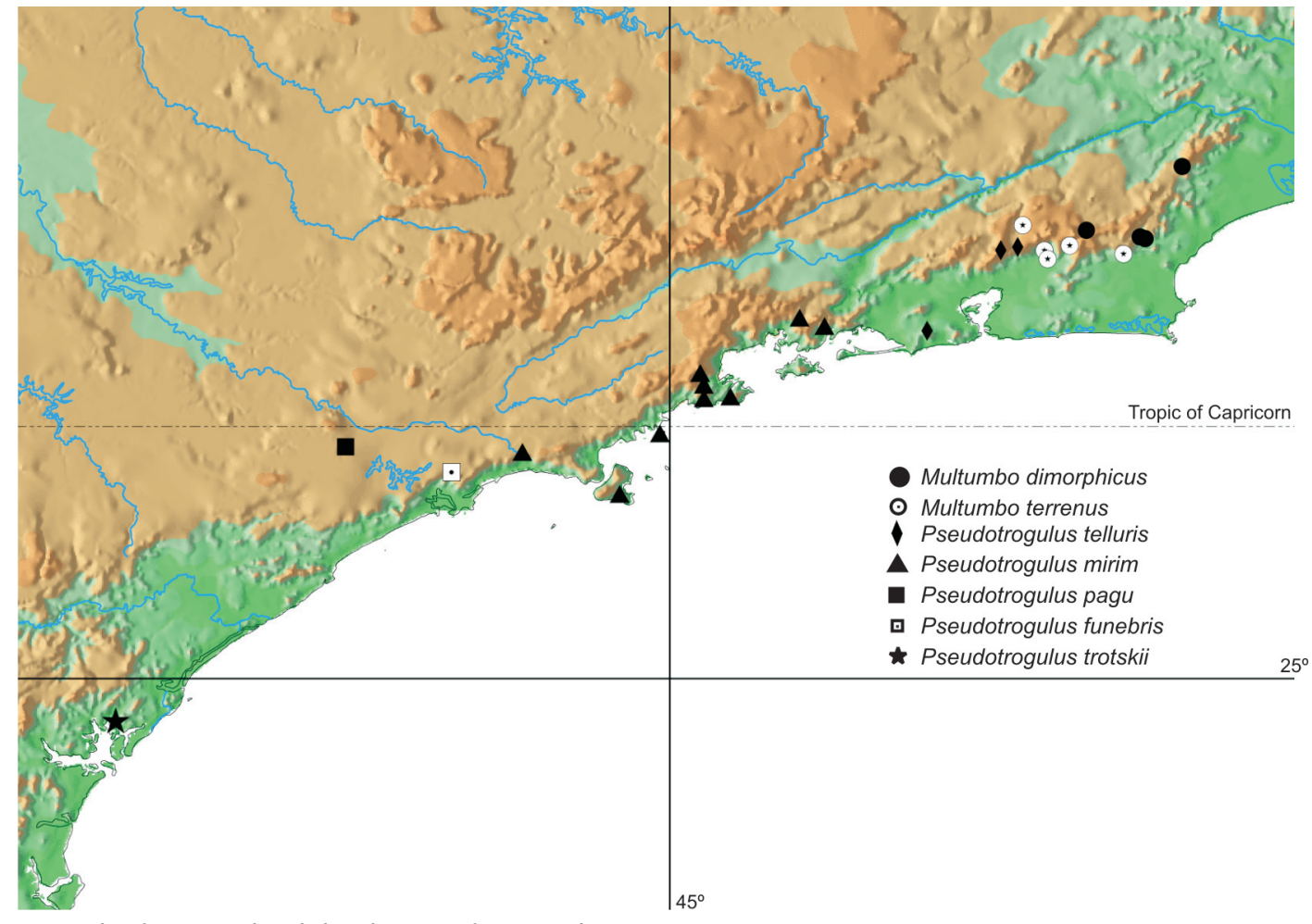

Figure 189. Records of geographical distribution of Hernandariinae.

in the isolation and speciation of harvestmen. The historical biogeographic analysis with the groups cited above resulted in eleven areas of endemism from Bahia to Santa Catarina. The analysis showed possible past vicariant events following a northto-south sequence that separated the opilionid fauna of these areas.

Hernandariinae species follow the same pattern of high endemism of the Atlantic Rain Forest harvestmen, with 15 of 22 species restricted to one of the areas of endemism proposed by Pinto-DA-Rocha et al. (2005). They are restricted to the Serra dos Órgãos - Org (three species, Multumbo spp. and Pseudotrogulus telluris), the Serra do Mar of São Paulo - SMSP (Piassagera brieni, Pseudotrogulus funebris and P. pagu), the Southern part of São Paulo - SSP (Hernandaria sundermannorum), the Paraná - PR (P. trotskyi and $H$. setulosa), and the Santa Catarina - SC (Acrogonyleptes pectinifemur, A. rhinoceros, A. granulatus, $H$. anitagaribaldiae, $H$. zumbii, and $H$. chicomendesi) areas of endemism. The exceptions are: H. heloisae (Fig. 186) which has been recorded in three areas (SSP, SMSP, and PR); A. cheguevarai (Fig. 188) which is endemic to Rio Grande do Sul (an area not delimited by PINTO-DA-Rocha et al. 2005); H. una (Fig. 188) and A. exochus (Fig. 186, both recorded in SC and PR); and H. armatifrons, H. scabricula, and $A$. spinifrons, mentioned above.

On the other hand, the subfamily range is displaced, by lacking species in northern regions and being present in south- ern regions outside Atlantic Forest limits when compared to many harvestmen taxa endemic to Atlantic Rain Forest, such as the four subfamilies previously cited, along with Bourguyiinae, Tricommatinae, and Mitobatinae. Based on the historical scenario proposed by PINTO-DA-Rocha et al. (2005) and complemented with distributional data of Bourguyiinae (Yamaguti \& PinTo-DARосна, 2009), we can suggest some causes for the differences in Hernandariinae distribution.

First, these works and some others (e.g., CRACRAFT \& PRUM 1988, AMorim \& Pires 1996, Bates et al. 1998, Ron 2000, Eberhard $\&$ BERMingham 2005) have pointed to a common origin for most of the biota in the Atlantic Rain Forest, and its close relationship with the Amazon forest biota. Furthermore, the region where Hernandariinae lives, from Org to SC was secondarily separated from northern areas (AMORIm \& Pires 1996, Pinto-dARocha et al. 2005, Yamaguti \& Pinto-da-Rocha 2009). Then, based on this historical scenario, Hernandariinae would have arisen in the southern region of the Atlantic Rain Forest, with a few extinctions (or unknown species) in two areas of endemism: Serra da Mantiqueira (Mnt) and Serra da Bocaina (Boc). Second, some species would have dispersed inland and to southern open areas. The unique distributional patterns of $H$. scabricula and $H$. armatifrons corroborate this hypothesis: these two species are sister taxa and the remaining Hernandaria species are from coastal ombrophilous forest. 
The species ranges and phylogenetic patterns of Hernandariinae indicate the group as being a good subject for historical biogeography studies in the Atlantic Forest. The high endemism of species can complement the delimitation of areas of endemism by PinTo-DA-Rocha et al. (2005). The clade Multumbo+Piassagera+Pseudotrogulus living in the central areas of endemism (Org, LSRJ, SMSP) contrast to clade Hernandaria+ Acrogonyleptes living in the southern areas (PR, SC), which can provide considerable empirical data for a new proposition for the evolution of the Atlantic Rain Forest biota. With the present review, Hernandariinae should be used in any future biogeographical study of this biome.

\section{ACKNOWLEDGEMENTS}

This paper is part of a Ph.D. thesis by MBS presented on March 2008 in the Instituto de Biociências of the Universidade de São Paulo. We are grateful to Cristina Rheims who kindly reviewed the language, Marcos Ryotaro Hara for manuscript review, Adriano B. Kury, Antonio C. Marques, Dalton S. Amorim, and Sílvio Nihei for a review of the original thesis, and two anonymous referees. We thank curators who loaned the material. FAPESP provided fellowship (MBS, \#03-02673-0) and grant (RPR, \#0806604-7). CNPq provided grant (RPR, \#472960/2008-3). We thank André A. Nogueira, Humberto Y. Yamaguti, Lia B. Monguillot, Cibele Bragagnolo, Marco C. Silveira, Marcos R. Hara, Fabiana C. Pioker, and Gustavo E. Kaneto for help during collecting trips.

\section{LITERATURE CITED}

AcostA, L.E. 1996. Die Typus-Exemplare der von Carl-Friedrich Roewer beschriebenen Pachylinae (Arachnida: Opiliones: Gonyleptidae). Senckenbergiana Biologica 76 (1/2): 209-225.

Acosta, L.E.; A. Pérez-GonZalez \& A.L. Tourinho. 2007. Chapter 15: Methods and Techniques of Study: Methods for taxonomic study, p. 494-505. In: G. Machado; R. PinTo-DARocha \& G. Giribet G. (Eds). Harvestmen, the biology of Opiliones. Cambridge, Harvard University Press.

Amorim, D.S. 1982. Classificação por seqüenciação: uma proposta para a denominação dos ramos retardados. Revista Brasileira de Zoologia 1 (1): 1-9.

AMorim, D.S.; M.E. Araújo \& A.M. Sole. 1993. Origin of evolutionary novelties and elimination of plesiomorphic alleles: some comments on limitations of the concept of synapomorphy. Revista Brasileira de Genética 16 (1): 245-252.

Amorim, D.S. \& M.R.S. Pires. 1996. Neotropical biogeography and a method for a maximum biodiversity estimation, $\mathrm{p}$. 183-219. In: C.E.M. Bicudo \& N.A. Menezes (Eds). Biodiversity in Brazil. A first approach. São Paulo, Conselho Nacional de Desenvolvimento Científico e Tecnológico.

Bates, J.M.; S.J. Hackett \& J. Cracraft. 1998. Area-relationships in the Neotropical lowlands: an hyphothesis based on raw distributions of Passerine birds. Journal of Biogeography 25: 783-793.
Bremer, K. 1994. Branch support and tree stability. Cladistics 10: 295-304.

Bragagnolo, C.; A.A. Nogueira; R. Pinto-Da-Rocha \& R. Pardini. 2007. Harvestmen in an Atlantic forest fragmented landscape:Evaluating assemblage response to habitat quality and quantitty. Biological Conservation 139: 389-400.

Canals, J. 1936. Observaciones biológicas en arácnidos del orden Opiliones. Revista Chilena de História Natural 40: 61-63.

Canals, J. 1943. Descripción de nuevos géneros y especies de Opiliones de la subfamilia Pachylinae. Notas del Museo de la Plata, Zoologia, 8 (63): 1-22.

Capocasale, R. 1966. Opiliones del Uruguay. Discocyrtus prospicuus Holmberg, el alotipo hembra de Pygophalangodus gemignanii uruguayensis Ringuelet (Gonyleptidae) y Metalibitia rosascostai sp. nov. (Cosmetidae). Bulletin du Muséum National D'Histoire Naturelle 37 (4): 631-644.

Capocasale, R. 1968. Nuevos aportes para el conocimiento de la distribucion geografica de los opiliones de Uruguay. Neotropica 14 (44): 65-71.

Capocasale, R. 2003. Diversidad de la biota uruguaya. Opiliones. Anales del Museo de Historia Natural y Antropología 10 (2): $1-8$.

Carpenter, J. M. 1988. Choosing among multiple equally parsimonious cladograms. Cladistics 4: 291-296.

Carpenter, J. M. 1994. Successive weighting, reliability and evidence. Cladistics 10: 215-220.

Cracraft, J. \& R.O. Prum. 1988. Patterns and processes of diversification: speciation and historical congruence in some Neotropical birds. Evolution 42 (3): 603-620.

Curtis, D.J. \& G. Machado. 2007. Ecology, p. 280-308. In: R. Pinto-Da-Rocha; G. Machado \& G. Giribet (Eds). Harvestmen: the biology of Opiliones. Cambridge, Harvard University Press.

DaSilva, M.B. \& P. Gnaspini. 2009. A systematic revision of Goniosomatinae (Arachnida: Opiliones: Gonyleptidae), with a cladistic analysis and biogeographical notes. Invertebrate Systematics 23: 530-624.

DaSilva, M.B. \& A.B. Kury. 2007. On the loss of sexual dimorphism in the Hernandariinae now including Multumbo Roewer and Piassagera Roewer (Opiliones, Gonyleptidae). Zootaxa 1558: 29-37.

Eberhard, J.R. \& E. Bermingham. 2005. Phylogeny and comparative biogeography of Pionopsitta parrots and Pteroglossus toucans. Molecular Phylogenetics and Evolution 36: 288-304.

FARRIS, J.S. 1969. A successive aproximations approach to character weighting. Systematic Zoology 18 (4): 374-385.

Firmo, C.L. \& R. Pinto-da-Rocha. 2002. A new species of Pseudotrogulus Roewer and assignment of the genus to the Hernandariinae (Opiliones, Gonyleptidae). Journal of Arachnology 30: 173-176.

Frers, A.G. 1917. Nota sobre "Apembolephaenus Jorgei" Holmberg. Comunicaciones de la Sociedad Argentina de Ciencias Naturales, Physis, 3: 405-406. 
Giltay, L. 1930. Liste des Arachnides brésiliens récoltés par la Mission belgo-brésilienne Jean Massart, p. 234-245. In: R. Boulllenne; P. Ledoux; P. Brien \& A. Navez. Une Mission Biologique Belge au Brésil, 2. Bruxelles, Imprimerie Medicale et Scientifique.

Gnaspini, P.; M.B. DaSilva \& F.C. Pioker. 2004. The occurrence of two adult instars among Grassatores (Arachnida: Opiliones) - A new type of life-cycle in arachnids. Invertebrate Reproduction and Development 45 (1): 29-39.

Gnaspini, P. \& M.R. Hara. 2007. Defense mechanisms, p. 374399. In: R. Pinto-da-Rocha; G. Machado \& G. Giribet (Eds). Harvestmen: the biology of Opiliones. Cambridge, Harvard University Press.

Goloboff, P. 1993. Estimating character weights during tree search. Cladistics 9: 83-91.

Goloboff, P. 1999. Nona, ver. 2.0. Tucumán, Published by author.

Goloboff, P.; J.S. Farris \& K. Nixon. 2003. T.N.T.: Tree Analysis Using New Technology. Available online at: http:// www.zmuc.dk/public/phylogeny [Acessed: 9.III.2009].

Goodnight, J.C. \& M.L. Goodnight. 1947. Studies on the phalangid fauna of Central America. American Museum Novitates 1340: 1-21.

Hara, M.R. \& P. Gnaspini. 2003. Comparative study of the defensive behavior and morphology of the gland opening area among harvestmen (Arachnida, Opiliones, Gonyleptidae) under a phylogenetic perspective. Arthropod, Structure \& Development 32: 257-275.

Hara, M.R. \& R. Pinto-DA-Rocha. 2010. Systematic review and cladistic analysis of the genus Eusarcus Perty, 1833 (Arachnida, Opiliones, Gonyleptidae). Zootaxa.

Holmberg, E.L. 1909. Gonyleptidarum novum genus. Apuntes de Historia Natural de Buenos Aires Zoologia 1 (3): 38-39.

ICZN. 1999. International Code of Zoological Nomenclature. International Commission of Zoological Nomenclature, $4^{\text {th }}$ ed., available online at: http://www.iczn.org/iczn [Acessed: 9.III.2009].

Kästner, A. 1937. Chelicerata. 7. Ordnung der Arachnida: Opiliones Sundeval $=$ Weberknechte, p. 300-393. In: W. Kukenthal \& T. Krumbach. Handbuch der Zoologie. Berlin, Walter de Gruyter and Co., vol. 3.

Kornet, D.J. \& H. Turner. 1999. Coding polymorphism for phylogeny reconstruction. Systematic Biology 48 (2): 365-379.

KunY, A.B. 1989. Notes on Mitobatinae III: a remarkable new Brazilian species of Mitobates Sundevall, 1833 (Opiliones, Laniatores, Gonyleptidae). Boletim do Museu Nacional Rio de Janeiro (N. S., Zoologia) 328: 1-12.

KurY, A.B. 1990. Synonimic notes on Mitobates Sundevall, with redescription of the type species, $M$. conspersus (Perty) (Opiliones: Gonyleptidae: Mitobatinae). Bulletin of the British Arachnology Society 8 (6): 194-200.

KuRY, A.B. 1992. The false Cranainae of the brazilian Atlantic Forest (Opiliones, Gonyleptidae). Tropical Zoology 5 (2): 279-291.

KurY, A.B. 1994. On the identity of the enigmatic Leptocnema Koch (Arachnida, Opiliones, Gonyleptidae). Mitteilungen aus dem Zoologisches Museum in Berlin 70 (1): 93-98.

KuRY, A.B. 1997. The genera Saramacia and Syncranaus Roewer, with note on the status of the Manaosbiidae (Opiliones, Laniatores, Gonyleptoidea). Boletim do Museu Nacional do Rio de Janeiro 374: 1-22.

KunY, A.B. 2003. Annotated catalogue of the Laniatores of the New World (Arachnida, Opiliones). Revista Ibérica de Aracnología, vol. esp. monográfico (1): 5-337.

KunY, A.B. 2007. Laniatores, p. 159-246. In: R. Pinto-DA-Rocha; G. Machado \& G. Giribet (Eds). Harvestmen: the biology of Opiliones. Cambridge, Harvard University Press.

Kury, A.B. \& G. Giribet. 2007. Phylogeny and biogeography, p. 62-87. In: R. Pinto-da-Rocha; G. Machado \& G. Giribet (Eds). Harvestmen: the biology of Opiliones. Cambridge, Harvard University Press.

Kury, A.B. \& R. Pinto-DA-Rocha. 1997. Notes on the Brazilian harvestmen genera Progonyleptoidellus Piza and Iporangaia Mello-Leitão (Opiliones, Gonyleptidae). Revista Brasileira de Entomologia 41 (1): 109-115.

Kury, A.B. \& R. Pinto-Da-Rocha. 2007. Gonyleptidae Sundevall, 1833, p. 196-203. In: R. Pinto-Da-Rocha; G. Machado \& G. GIRIBET (Eds). Harvestmen: the biology of Opiliones. Cambridge, Harvard University Press.

LeE, D.C. \& H.N. Bryant. 1999. A reconsideration of the coding of inapplicable characters: assumptions and problems. Cladistics 15: 373-378.

Lipscomb, D.L. 1992. Parsimony, homology and the analysis of multistate characters. Cladistics 8: 45-65.

Machado, G. \& R. Macías-Ordóñez. 2007a. Social behavior, p. 400-413. In: R. PINTO-DA-Rocha; G. Machado \& G. Giribet (Eds). Harvestmen: the biology of Opiliones. Cambridge, Harvard University Press.

Machado, G. \& R. Macías-OrdóÑez. 2007b. Reproduction, p. 414454. In: R. Pinto-da-Rocha; G. Machado \& G. Giribet (Eds). Harvestmen: the biology of Opiliones. Cambridge, Harvard University Press.

Machado, G.; G.S. Requena \& B.A. Buzatto. 2009. Comportamento reprodutivo de opiliões (Arachnida): sistemas de acasalamento e cuidado parental. Oecologia Brasiliensis 13 (1): 58-79.

Machado, S.F.; R.L. Ferreira \& R.P. Martins. 2003. Aspects of the population ecology of Goniosoma sp (Arachnida Opiliones Gonyleptidae) in limestone caves in southeastern Brazil. Tropical Zoology 16 (1): 13-31.

Mello-Leitão, C.F. 1923. Opiliões Laniatores do Brasil. Arquivos do Museu Nacional, Rio de Janeiro 24: 105-197.

Mello-Leitão, C.F. 1926. Notas sobre Opiliones Laniatores sulamericanos. Revista do Museu Paulista 14: 327-383.

Mello-Leitão, C.F. 1927a. Arachnideos de Santa Catharina. Revista do Museu Paulista 15: 395-419.

Mello-Leitão, C.F. 1927b. Generos novos de Gonyleptideos (nota prévia). Boletim do Museu Nacional do Rio de Janeiro 3 (2): 13-22. 
Mello-Leitão, C.F. 1930a. Gonyleptidas novos ou pouco conhecidos da Republica Argentina, da subfamilia Pachylinae. Annais da Academia Brasileira de Ciências 2 (3):137-142.

Mello-LeITÃo, C.F. 1930b. Nota sobre Arachnideos argentinos. Annais da Academia Brasileira de Ciências 2 (4): 211-214.

Mello-LeITÃo, C.F. 1931a. Opiliões novos ou críticos. Arquivos do Museu Nacional do Rio de Janeiro 33 (3):117-148.

Mello-Leitão, C.F. 1931b. Nota sobre arachnideos argentinos. III Opiliões novos ou críticos. IV Aranhas novas. Annais da Academia Brasileira de Ciências 3 (2): 83-97.

Mello-Leitão, C.F. 1932. Opiliões do Brasil. Revista do Museu Paulista 17 (2): 1-505.

Mello-LeitÃo, C.F. 1933a. Notas sobre os opiliões do Brasil descritos na obra póstuma de Sørensen: "Descriptiones Laniatorum". Boletim do Museu Nacional do Rio de Janeiro 9 (2): 99-114.

Mello-Leitão, C.F. 1933b. Novos Gonyléptidae do Brasil Meridional. Archivos da Escola Superior de Agricultura e Medicina Veterinária 10 (2): 133-151.

Mello-Leitão, C.F. 1935. Algumas notas sobre os Laniatores. Arquivos do Museu Nacional do Rio de Janeiro 36: 89-116.

Mello-Leitão, C.F. 1939. Les Arachnides et la zoogéographie de l'Argentine. Physis 17: 601-630.

Mello-Leitão, C.F. 1949. Famílias, subfamília, espécies e gêneros novos de opiliões e notas de sinonímia. Boletim do Museu Nacional do Rio de Janeiro 94: 1-33.

MuÑoz Cuevas, A. 1973. Sur les caractères génériques de la famille des Gonyleptidae (Arachnida, Opilions, Laniatores). Bulletin du Muséum National D'Histoire Naturelle 87 (113): 225 234.

Nixon, K. C. 1999. Winclada (BETA) ver. 0.9.9. New York, Published by author, Ithaca.

PAGE, R.D.M. 2001. NEXUS Data Editor 0.5.0. Available online at: http://taxonomy.zoology.gla.ac.uk/rod/NDE/ [Acessed: 9.III.2009].

Pimentel, R.A. \& R. Riggins. 1987. The nature of cladistic data. Cladistics 3: 201-209.

PinTo-DA-Rocha, R. 1994. A new species of Santinezia from central Amazonia, with systematic comments on the genus (Arachnida, Opiliones, Cranaidae). Andrias 13: 29-32.

PINTO-DA-Rocha, R. 1997. Systematic review of the neotropical family Stygnidae (Opiliones, Laniatores, Gonyleptoidea). Arquivos de Zoologia 33 (4): 163-342.

PINTO-DA-Rocha, R. 2002. Systematic review and cladistic analysis of the Brazilian subfamily Caelopyginae (Opiliones: Gonyleptidae). Arquivos de Zoologia 36 (4): 357-464.

Pinto-da-Rocha, R. \& S. Caron. 1989. Catálogo do Material-tipo da coleção de Arachnida Rudolf Bruno Lange do Museu de História Natural "Capão de Imbuia", Curitiba, Paraná, Brasil. Revista Brasileira de Biologia 49 (4): 1021-1029.

Pinto-DA-Rocha, R. \& G. Giribet. 2007. Taxonomy, p. 88-246. In: R. Pinto-DA-Rocha; G. Machado \& G. GiRibet (Eds). Harvestmen: the biology of Opiliones. Cambridge, Harvard University Press.
Pinto-Da-Rocha, R.; G. Machado \& G. GiRibet. 2007. Harvestmen: the biology of Opiliones. Cambridge, Harvard University Press.

Pogue, M.G. \& M.F. Mickevich. 1990. Character definitions and character state delineation: the bête noire of phylogenetic inference. Cladistics 6: 319-361.

Ringuelet, R.A. 1955a. Noticias sobre los Opiliones del Uruguay. Notas del Museo de La Plata 18 (163): 279-297.

Ringuelet, R.A. 1955b. Los Opiliones misioneros. Boletín de la Sociedad Entomológica Argentina 6-7: 1-2.

Ringuelet, R.A. 1955c. Noticias sobre los Opiliones del Uruguay. Boletín de la Sociedad Entomológica Argentina 6-7: 7.

Ringuelet, R.A. 1957. Biogeografia de los aracnidos argentinos del oden Opiliones. Contribuciones Cientificas de la Universidad de Buenos Aires 1 (1): 5-33.

Ringuelet, R.A. 1959. Los aracnidos argentinos del orden Opiliones. Revista del Museo Argentino de Ciencias Naturales "Bernardino Rivadavia" 5 (2): 125-439.

Ringuelet, R.A. 1963. Opiliofauna Uruguaya. Revista de la Sociedad Entomologica Argentina 24: 35-51.

Rodrigo, A. 1992. Two optimality criteria for selecting subsets of most parsimonious trees. Systematic Biology 41 (1): 33-40.

Roewer, C.F. 1913. Die Familie der Gonyleptiden der OpilionesLaniatores. Archiv für Naturgeschichte 79A (4): 1-256 and 79A (5): 257-473.

Roewer, C.F. 1917. 52 neue Opilioniden. Archiv für Naturgeschichte 82A (2): 90-158.

Roewer, C.F. 1923. Die Weberknechte der Erde. Systematische Bearbeitung der bisher bekannten Opiliones. Jena, Gustav Fischer.

RoEwER, C.F. 1927. Brasilianische Opilioniden, gesammelt von Herrn Prof. Bresslau in Jahre 1914. Abhandlungen der Senckenbergischen Naturforschenden Gesellschaft 40 (3): 333-352.

Roewer, C.F. 1928. Opilions nouveaux de Brésil. Bulletin et Annales de la Société Entomologique de Belgique 68: 123127.

Roewer, C.F. 1929. Weitere Weberknechte III. III. Ergänzung der: "Weberknechte der Erde", 1923. Abhandlungen Naturwissenschaftlichen Verein Zu Bremen 27 (2): 179-284.

RoEwer, C.F. 1930. Weitere Weberknechte IV. IV. Ergänzung der: "Weberknechte der Erde", 1923. Abhandlungen Naturwissenschaftlichen Verein Zu Bremen 27 (3): 341-452.

Roewer, C.F. 1931. Weitere Weberknechte V. V. Ergänzung der: "Weberknechte der Erde", 1923. Abhandlungen Naturwissenschaftlichen Verein Zu Bremen 28 (2-3): 101-164.

Roewer, C.F. 1932 Weitere Weberknechte VII (7.Ergänzung der Webernechte der Erde, 1923). Archiv für Naturgeschichte, Berlin 1 (2): 275-350.

Roewer, C.F. 1943. Weitere Weberknechte XI. Über Gonyleptiden. Senckenbergiana 26 (1-3): 12-68.

Ron, S.R. 2000. Biogeographic area relationships of lowland Neotropical rainforest based on raw distributions of vertebrate groups. Biological Journal of Linnean Society 71: 379-402. 
SoARes, B.A.M. 1943. Alguns opiliões do estado de Paraná. Archivos do Museu Paranaense 3: 205-213.

SoARES, B.A.M. 1944. Notas sobre opiliões da coleção do Museu Nacional do Rio de Janeiro. Papéis Avulsos do Departamento de Zoologia do Estado de São Paulo 6 (15): 163-180.

SoAres, B.A.M. 1945a. Opiliões do Paraná. Arquivos do Museu Paranaense 4 (8): 191-206.

SOARES, B.A.M. 1945b. Opiliões da coleção do Museu Nacional do Rio de Janeiro. Arquivos de Zoologia do Estado de São Paulo 4 (9): 341-393.

SoAres, B.A.M. \& H.E.M. SoAres. 1945. Mais opiliões pertencentes ao Museu Paranaense. Revista Agrícola, Piracicaba 20 (9-12): 365-377.

SoAres, B.A.M. \& H.E.M. SoAres. 1946. Novos Opiliões de Banhado (Estado do Paraná). Papéis Avulsos do Departamento de Zoologia do Estado de São Paulo 7 (8): 101-111.

SoAres, B.A.M. \& H.E.M. Soares. 1947a. Opiliões paranaenses da coleção Joram Leprevost. Papéis Avulsos do Departamento de Zoologia 8 (12): 137-144.

Soares, B.A.M. \& H.E.M. Soares. 1947b. Opiliões da coleção Gofferjé (Opiliones - Gonyleptidae). Papéis Avulsos do Departamento de Zoologia 8 (21): 249-259.

SoARES, B.A.M. \& H.E.M. SoAres. 1948. Monografia dos gêneros de opiliões neotrópicos I. Arquivos de Zoologia do Estado de São Paulo 5 (9): 553-635.

Sodres, B.A.M. \& H.E.M. Soares. 1949. Monografia dos gêneros de opiliões neotrópicos II. Arquivos de Zoologia do Estado de São Paulo 7 (2): 151-239.

SoAres, B.A.M. \& H.E.M. Soares. 1954. Monografia dos gêneros de opiliões neotrópicos III. Arquivos de Zoologia do Estado de São Paulo 8 (9): 225-302.

SOARES, H.E.M. 1945. Contribuição ao estudo dos opiliões do Estado do Paraná. Arquivos do Museu Paranaense 4 (9): 207-230.

SOARES, H.E.M. 1966a. Opiliões da coleção Gofferjé (Opiliones: Gonyleptidae, Phalangodidae). Papéis Avulsos do Departamento de Zoologia do Estado de São Paulo 18 (10): 77-102.

SoARES, H.E.M. 1966b. Opiliões pertencentes à coleção "Eugênio W. Gruman" (Opiliones, Cosmetidae, Gonyleptidae). Papéis Avulsos do Departamento de Zoologia do Estado de São Paulo 18 (12): 117-123.

SOARES, H.E.M. 1972. Opera Opiliologica Varia. II (Opiliones: Gonyleptidae, Phalangiidae, Phalangodidae). Revista Brasileira de Biologia 32 (1): 65-74.

SOARES, H.E.M. \& B.A.M. SOARES. 1984. Opera opiliologica varia XXV. (Opiliones, Gonyleptidae). Revista Brasileira de Entomologia 28 (3): 301-314.

SOARES, H.E.M. \& B.A.M. SOAREs. 1985a. Opera opiliologica varia XXII (Opiliones: Gonyleptidae). Naturalia 10: 157-200.

SoAres, H.E.M. \& B.A.M. Soares. 1985b. Contribution à l'étude dês opilions (Opiliones: Cosmetidae, Phalangodidae, Gonyleptidae) du Paraguay. Revue suisse de Zoologie 92 (1): 3-18.

Soares, H.E.M. \& M.J. Bauab-Vianna. 1972. Algunas notas sobre opiliones com la descripcion de allotypi y nuevas formas (opiliones, Gonyleptidae). Physis, Secc. C, 31 (82): 203-218.

Sørensen, W. 1884. Opiliones Laniatores (Gonyleptides W. S. Olim) Musei Hauniensis. Naturhistorisk Tidsskrift 14 (3): 555-646.

Sørensen, W. 1895. Viaggio del dottor A. Borelli nella Republica Argentina e nel Paraguay. XVII Opiliones Laniatores. Bollettino dei Musei di Zoologia ed Anatomia Comparata della R. Università di Torino 10 (210): 1-6.

Sørensen, W. 1902. Gonyleptiden (Opiliones Laniatores). Hamburger Magalhaensische Sammelreise 5: 1-36.

Sørensen, W. 1932. Descriptiones Laniatorum (Arachnidorum Opilionum Subordinis). (Opus posthumum recognovit et edidit Kai L. Henriksen). Det Kongelige Danske Videnskabernes Selskabs Skrifter., Naturvidenskabelig og Mathematisk Afdeling (= Mémoires de l'Académie Royale des Sciences et des Lettres de Danemark, København), ser. 9, 3 (4): 197-422.

Strong, E.E. \& D. Lipscomb. 1999. Character coding and inapplicable data. Cladistics 15: 363-371.

Swofford, D.L. 2002. PAUP*. Phylogenetic Analysis Using Parsimony (*and Other Methods). Version 4. Sunderland, Sinauer Associates.

TAVARES, M.L.R. 1980. Novas ocorrências de opiliões no Rio Grande do Sul e descrição da femêa de Melloleitaniana riodariensis Soares \& Soares, 1945 (Gonyleptidae). Iheringia 55: 155-159.

Tourinho, A.L. \& A.B. Kury. 2003. A review of Jussara, with descriptions of six new species (Arachnida, Opiliones, Sclerosomatidae) from Brazil. Tropical Zoology 16 (2): 209-275.

Valentinis de Martínez, S. 1974. Consideraciones ecológicas sobre algunas especies de opiliones (Aracnida) halladas en el Depto. La Capital (Santa Fe; Argentina). Comunicaciones del Museo Provincial de Ciencias Naturales "Florentino Ameghino", Zoologia, 7: 1-11.

VASCONCELOS, E.G. 2005. Notes on Geraecormobius clavifemur (MelloLeitão, 1927) and description of Geraecormobius reitzi n. sp. (Arachnida: Opiliones: Gonyleptidae). Zootaxa 1088: 1-10.

Wiens, J.J. 1995. Polymorphic characters in phylogenetic systematics. Systematic Biology 44 (4): 482-500.

WiLKINSON, M. 1995. A comparison of two methods of character construction. Cladistics 11: 297-308.

Willemart, R.H.; F. Osses; M.C. Chelini; R. Macías-Ordóñez \& G. MACHADO. 2009. Sexually dimorphic legs in a neotropical harvestman (Arachnida, Opiliones): Ornament or weapon? Behavioural Processes 80: 51-59.

Yamaguti, H.Y. \& R. Pinto-da-Rocha 2009. Taxonomic review of Bourguyiinae, cladistic analyisis, and a new hypothesis of biogeographic relationships of the Brazilian Atlantic Rainforest (Arachnida, Opiliones, Gonyleptidae). Zoological Journal of the Linnean Society 156: 319-362.

Submitted: 09.III.2009; Accepted: 25.III.2010.

Editorial responsibility: Antonio C. Marques 


\section{TAXONOMIC INDEX}

Descriptions and redescriptions pages are in bold.

Acanthogonyleptes.....

Acrogonyleptes $578,579,580,581,582,583,585$

$587,600,626,631$

Acrogonyleptoides .................................................. 578, 600

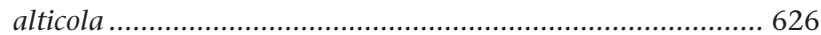
anitagaribalidiae ......... 588, 596, 598, 599, 620, 621, 627, 630 Apembolephaeninae ..................................................... 586

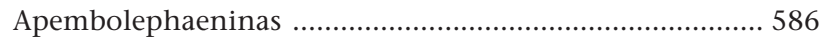
Apembolephaenus ................................................. 578, 587

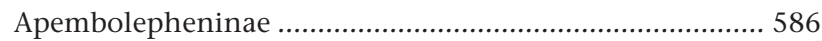

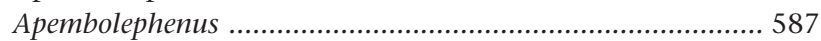
Ariaeus ................................................................ 578, 580 armatifrons ........ 581, 582, 587, 588, 591, 622, 626, 627, 630 Bourguyiinae .................................................. 577, 630 brieni ......... 579, 582, 584, 586, 612, 613, 614, 625, 627, 630 Caelopyginae ......................................... 577, 582, 583, 626

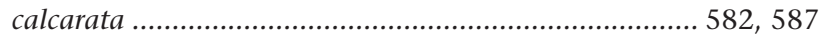
calcaratus ................................................................... 588 cheguevarai ........ 582, 601, 602, 604, 609, 611, 620, 624, 630 chicomendesi ............................. 588, 593, 599, 601, 621, 630 clavifemur ....................................................... 579, 580 curitibae ........................................ 579, 582, 601, 602, 606 dimorphicus ................................................ 579, 582,612

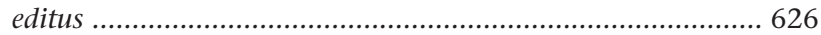

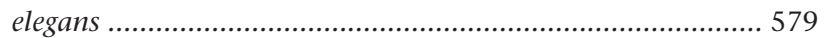
Eusarcus .................................................................... 578 exochus ............. 582, 600, 601, 602, 603, 609, 623, 627, 630

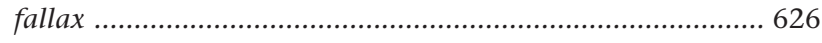

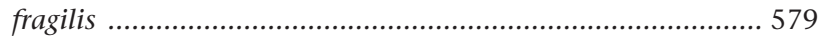
fulvigranulatus ..................................................... 579, 626 funebris ............. 578, 582, 584, 585, 615, 617, 625, 627, 630

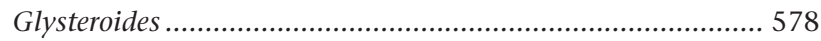

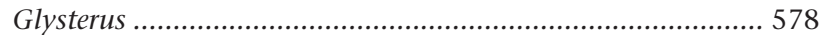
Goniosomatinae ........................................... 577, 583, 626 Gonyleptinae .................................................... 583, 584 granulatus .......... 582, 601, 602, 604, 605, 609, 620, 623, 630 heloisae ..................... 586, 588, 590, 591, 596, 620, 622, 630 Hernandaria ....... 578, 579, 581, 582, 583, 585, 587, 588, 631 Hernandariinae ......... 578, 580, 582, 583, 585, 586, 587, 630

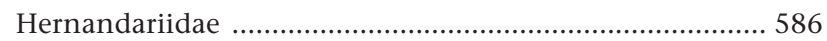

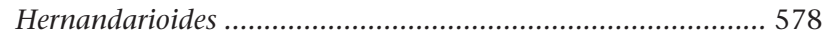

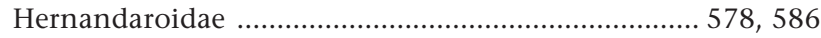

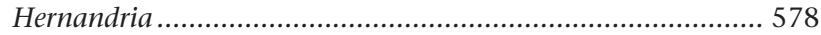

Heteropachylinae ............................................................ 577

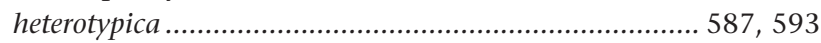

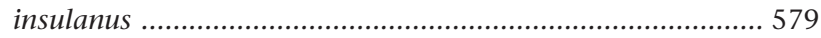
jorgei .................................................... 578, 579, 587, 591

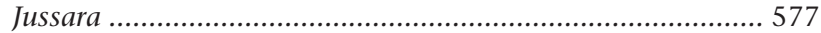

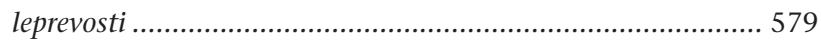

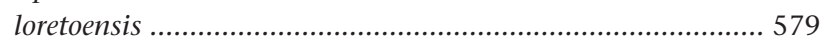

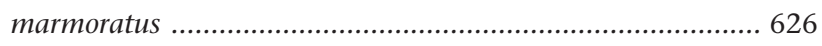

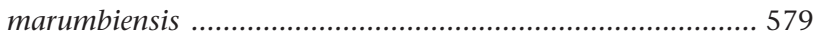

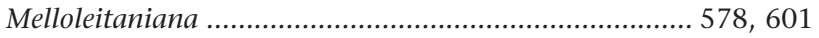

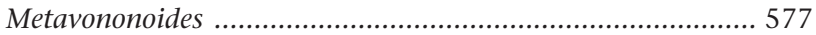

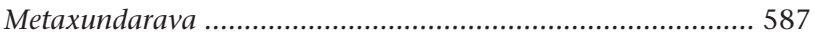

mirim ............... 578, 582, 584, 615, 616, 617, 621, 626, 627

Mischonyx .................................................. 577, 582, 583

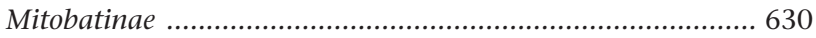

Multumbo .......... 579, 582, 583, 584, 585, 587, 611, 630, 631

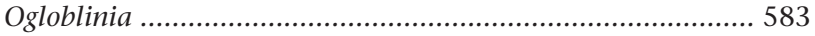

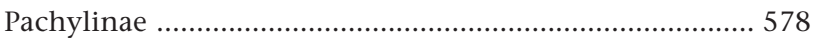

pagu ................. 582, 584, 585, 615, 618, 619, 620, 621, 630

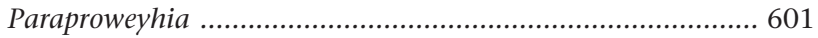

pectinifemur ............... 579, 582, 602, 604, 606, 607, 623, 630

Piassagera ............................... 579, 582, 583, 587, 612, 631

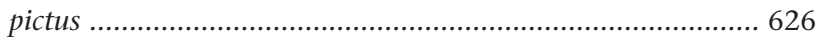

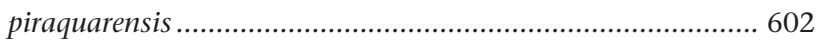

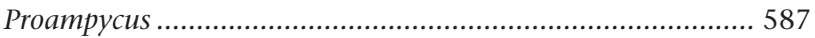

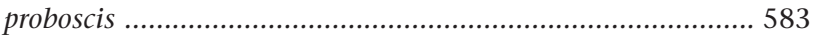

Progonyleptoidellinae ...................... 577, 582, 583, 584, 626

Proweyhia .............................................................. 578, 587

Pseudoacrogonyleptoides ............................................. 578, 601

Pseudotrogulus .... 578, 579, 582, 583, 585, 587, 614, 615, 630

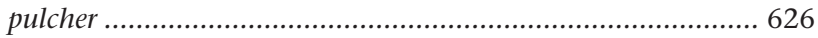
rhinoceros .................. 582, 600, 602, 604, 609, 610, 623, 630

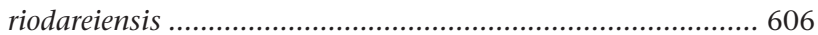

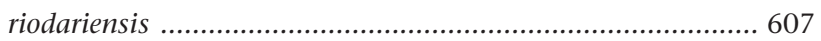

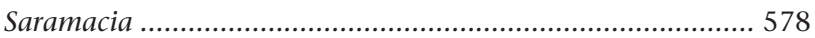

scabricula ... 578, 579, 582, 587, 588, 590, 592, 622, 626, 630

Sclerosomatidae .......................................................... 583

setulosa .................... 586, 587, 588, 593, 594, 599, 621, 630

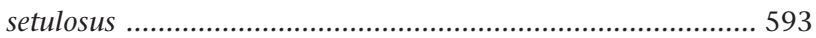

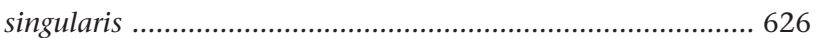

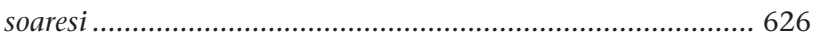

Sodreaninae …..................................577, 582, 583, 626

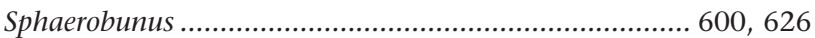

spinifrons (Acrogonyleptes) ........... 581, 582, 601, 602, 604, 606, $607,608,620,624,626,630$

spinifrons (Proampycus) ........................................ 587, 591

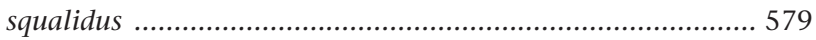

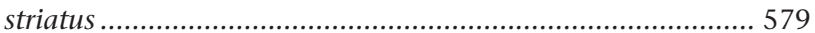

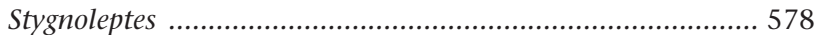

sundermannorum ........................ 588, 590, 596, 597, 621, 630 telluris ............... 578, 582, 584, 614, 615, 616, 617, 625, 630

terrenus ............................ 579, 583, 611, 612, 613, 625, 626

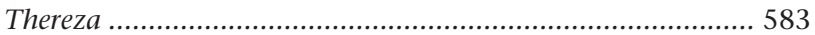

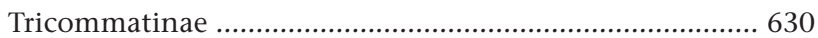

trochanteralis ........................................................ 579, 580

trotskyi ............................ 582, 615, 618, 619, 620, 621, 630

tuberculatus .................................................... 578, 579

una ….............. 581, 587, 588, 593, 595, 599, 622, 627, 630

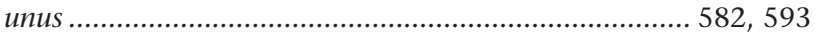

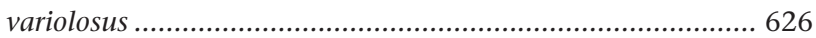

zumbii .............................. 584, 588, 596, 599, 600, 622, 630 
Appendix 1. List of characters used in cladistic analysis of Hernandariinae.

\section{Ocularium}

[1] Armature of ocularium (consensus: $L=11, \mathrm{ci}=.18 \mathrm{ri}=.47$; most parsimonious: $\mathrm{L}=10, \mathrm{ci}=.20 \mathrm{ri}=.52$ ):

0 . low tubercles (Fig 36);

1. spines (Fig 74);

2. enlarged tubercles (same height as ocularium - pair of tubercles covering entire roof of ocularium) (Fig 101).

[2] Number and direction of ocularium armature $(L=7, \mathrm{ci}=.28 \mathrm{ri}=.66)$ :

0 . paired armature and parallel (Fig 105);

1. paired armature and convergent (Fig 52);

2. single armature, placed in middle (Fig 57).

[3] Direction of ocularium armature in lateral $\operatorname{view}(\mathrm{L}=5, \mathrm{ci}=.20, \mathrm{ri}=.63)$ :

0 . perpendicular to dorsal scute (Fig 61);

1. oblique to dorsal scute (frontwards) (Fig 70)

[4] Ocularium height $(\mathrm{L}=2, \mathrm{ci}=.50, \mathrm{ri}=.80)$

0 . low (height less than 2 times eye diameter) (Fig 85)

1. high (height more than 3 times eye diameter) (Fig 103)

\section{Dorsal scute}

[5] Prosoma/opisthosoma length ratio $(L=1, c i=1, r i=1)$

0. near $1 / 2$ (Fig 88)

1. similar-sized (Fig 97)

[6] Shape of areas in lateral view $(\mathrm{L}=4, \mathrm{ci}=.25, \mathrm{ri}=.72)$

0 . humped (Fig 85)

1. flat (Fig 36)

[7] Number of ozopores (ordered; $L=2, c i=1, r i=1$ )

0. two openings (HARA \& GNASPINI 2003, Fig. 31)

1. one large opening (HARA \& GNASPINI 2003, Fig. 30)

2. one reduced opening (present article, Fig. 174)

[8] Camouflage with debris $(\mathrm{L}=2, \mathrm{ci}=.50, \mathrm{ri}=.87)$

0 . absent

1. present (Fig. 176)

[9] Median apophyses on anterior margin (ordered; $L=3, \mathrm{ci}=.66 \mathrm{ri}=.91$ )

0 . absent

1. small (Fig. 97)

2. enlarged (Fig. 88)

[10] Number and direction of median apophyses on anterior margin (consensus and most parsimonious: $\mathrm{L}=3, \mathrm{ci}=.66, \mathrm{ri}=.87$ )

0 . paired, separate (Fig. 92)

1. paired, convergent (Fig. 88)

2. single (Fig. 95)

[11] Lateral apophyses on anterior margin of dorsal scute (ordered; $L=4, \mathrm{ci}=.50, \mathrm{ri}=.80$ )

0 . absent

1. small apophyses

2. large apophyses (Fig. 95)

[12] Folding and row of tubercles between ocularium and anterior margin (ordered; $L=3, \mathrm{ci}=.66, \mathrm{ri}=.83$ )

0. absent (Fig. 95)

1. with weak tubercles, sparsely distributed (Fig. 98)

2. with strong tubercles, jointly distributed (Fig. 101)

[13] Armature (tubercles/spines) of mesotergal area III (ordered; $L=2, c i=1, r i=1$ )

0. paired, separate (Fig. 100)

1. paired, fused (Fig. 66)

2. single (Fig. 86)

ZOOLOGIA 27 (4): 577-642, August, 2010 
[14] Shape of armature (tubercles/spines) of mesotergal area III (ordered; $L=7, c i=.28, r i=.37$ )

0. conical (Fig. 51)

1. rounded (Fig. 42)

2. elliptical

[15] Size of armature of mesotergal area III (ordered; $L=7$, ci $=.28, \mathrm{ri}=.44$ )

0 . similar to those of area II (Fig. 39)

1. larger than those of area II (Fig. 33)

2. larger than any other elevation on the body

[16] Sexual dimorphism in size of armature of mesotergal area III $(L=5, c i=.20, r i=.63)$

0 . absent

1. present

[17] Number of mesotergal areas (ordered; $\mathrm{L}=7, \mathrm{ci}=.28, \mathrm{ri}=.68$ )

0 . three, area IV absent (Fig. 57)

1. four, area IV smaller than area III (Fig. 43)

2. four, area IV similar size as area III (Fig. 39)

[18] Dark patches on corners of mesotergal areas $(L=1, c i=1, r i=1)$

0 . absent

1. present (Fig. 183)

[19] Sexual dimorphism of armature on lateral margin of mesotergum $(L=4, c i=.25, r i=.62)$

0 . absent

1. present (Fig. 180 male and Fig. 181 female)

[20] Size of tubercles on lateral margin (ordered; $L=6, c i=.33, \mathrm{ri}=.66$ )

0 . similarly sized (Fig. 48)

1. some larger (Fig. 70)

2. one larger (Fig. 62)

[21] Whitish tubercles on lateral margin $(L=4, \mathrm{ci}=.25$, ri $=.66)$

0 . absent

1. present (Fig. 184)

[22] Whitish tubercles and granules on posterior region of dorsal scute $(L=4, \mathrm{ci}=.25, \mathrm{ri}=.25)$

0 . absent

1. present (Fig. 184)

[23] Whitish granules on whole dorsal scute $(L=3$, ci $=.33$, ri $=.0)$

0 . absent

1. present (Fig. 182)

[24] Shape of granules of anterior part of mesotergal area I $(\mathrm{L}=4, \mathrm{ci}=.25$, ri $=.70)$

0 . almost rounded (Fig. 28)

1. elongate (Fig. 62)

[25] Distribution of granules on mesotergal areas $(\mathrm{L}=3, \mathrm{ci}=.33, \mathrm{ri}=.83)$

0 . uniformly distributed (Fig. 23)

1. concentrated near sulci (Fig. 28)

[26] Size of most granules and tubercles $(L=1, c i=1, r i=1)$

0 . small (tubercles of area I smaller than eye diameter) (Fig. 28)

1. large (tubercles of area I larger than eye diameter) (Fig. 102)

[27] Size and shape of granulation on mesotergal areas $(\mathrm{L}=3, \mathrm{ci}=.33$, ri $=.75)$

0. similar to each other (Fig. 39)

1. different sizes and shapes (Fig. 88)

[28] Density of granulation (ordered; $L=7, \mathrm{ci}=.28, \mathrm{ri}=.70$ )

0 . low (scattered granules, some regions of dorsal scute smooth)

1. median (granules scattered throughout dorsal scute) (Fig. 39)

2. high (granules adjacent to each other) (Fig. 23) 


\section{Venter}

[29] Depth of stigmatic and genital areas $(L=3, \mathrm{ci}=.33$, ri =.60)

0 . shallow, the same height of coxa

1. deeper than coxa IV

[30] Camouflage with debris on stigmatic and genital areas $(L=1, c i=1, r i=1)$

0 . present

1. absent

[31] Ornamentation of stigmatic and genital areas (ordered; $L=3, \mathrm{ci}=.66, \mathrm{ri}=.85$ )

0 . many uniformly distributed granules

1. pair of tubercles and few granules

2. only a pair of tubercles

[32] Granulation of coxa IV $(\mathrm{L}=2, \mathrm{ci}=.50, \mathrm{ri}=.66)$

0 . similar to other parts

1. more dense and high, clearly contrasting with stigmatic and genital area

\section{Free tergites}

[33] Sexual dimorphism of ornamentation on posterior margin of dorsal scute and free tergites $(L=4, \mathrm{ci}=.25, \mathrm{ri}=.75)$

0 . absent

1. present (Figs 180-181)

[34] Ornamentation of male free tergites II and III $(L=4, \mathrm{ci}=.25, \mathrm{ri}=.78)$

0. similar-sized tubercles (Fig. 52)

1. larger spine or tubercle (Fig. 82)

[35] Ornamentation of female free tergites II and III ( $L=4, \mathrm{ci}=.25, \mathrm{ri}=.62)$

0 . similar-sized tubercles

1. larger spine

[36] Armature on male posterior margin of dorsal scute to free tergite III $(L=8, c i=.25, r i=.53)$

0 . tergite II and III with larger armature (Fig. 61)

1. similarly sized or slightly increasing in size antero-posteriorly (Fig. 21)

2. decreasing (larger anteriorly, on posterior margin) (Fig. 56)

[37] Armature on female posterior margin of dorsal scute to free tergite III $(L=6, c i=.33, r i=.60)$

0 . tergite II and III with larger armature

1. similarly sized or slightly increasing in size antero-posteriorly

2. decreasing (larger anteriorly, on posterior margin)

[38] Shape of armature on male posterior margin and free tergites $(L=7, \mathrm{ci}=.14, \mathrm{ri}=.57)$

0 . conical tubercles or spines (Fig. 48)

1. rounded tubercles (Fig. 13)

[39] Shape of armature on female posterior margin and free tergites $(L=4, \mathrm{ci}=.25, \mathrm{ri}=.66)$

0 . spines

1. rounded tubercles

[40] Huge tubercle or spine (much larger than any other; more than twice the length of tergite) on free tergite III $(L=3, \mathrm{ci}=.33, \mathrm{ri}=.33)$

0 . absent (Fig. 65)

1. present (Fig. 99)

[41] Row of high and juxtaposed granules on lateral margin of main elevation of free tergite III $(\mathrm{L}=2, \mathrm{ci}=.50, \mathrm{ri}=0)$

0. absent (Fig. 97)

1. present (Fig. 100)

\section{Pedipalp}

[42] Femur width $(\mathrm{L}=2$, ci $=.50, \mathrm{ri}=.80)$

0 . wide (diameter similar to tibia and tarsus) (Fig. 112)

1. thin (diameter much narrower than tibia and tarsus) (Fig. 114)

ZOOLOGIA 27 (4): 577-642, August, 2010 
[43] Venter of tarsus $(\mathrm{L}=2, \mathrm{ci}=.50, \mathrm{ri}=.83)$

0. straight (Fig. 116)

1. convex (Fig. 114)

[44] Ectal armature of tarsus $(\mathrm{L}=4, \mathrm{ci}=.25, \mathrm{ri}=.50)$

0. lil (Fig. 113)

1. II (Fig. 114)

[45] Pair of regular longitudinal median row of small setae on venter of tarsus $(L=1, c i=1, r i=1)$

0 . absent

1. present

\section{Legs}

[46] Ventral tubercles of leg I $(L=3, \mathrm{ci}=.33, \mathrm{ri}=.83)$

0. normal (Fig. 94)

1. enlarged (Fig. 55)

[47] Male basitarsus ( $\mathrm{L}=6, \mathrm{ci}=.16, \mathrm{ri}=.54$ )

0 . similar diameter to other tarsal articles (Fig. 111)

1. swollen (Fig. 99)

[48] Number of tarsomeres of leg I (ordered; $L=3$, ci $=.75$, ri $=.91$ )

0 . more than eight

1. six or seven

2. five

3. three

[49] Number of tarsomeres of leg III (ordered; $L=10, \mathrm{ci}=.40$, ri $=.66$ )

0 . more than 16

1. nine

2. seven

3. six

4. five

[50] Metatarsus IV of male $(\mathrm{L}=2, \mathrm{ci}=.50, \mathrm{ri}=0)$

0 . normal

1. swollen

[51] Arrangement of armature on legs I-III $(\mathrm{L}=2, \mathrm{ci}=.50$, ri $=.85)$

0 . tubercles/spines of different sizes in slightly sinuous rows (Fig. 94)

1. tubercles/spines of similar size in regular rows (Fig. 55)

[52] Ventral tubercles on femora of legs II-IV $(L=2, \mathrm{ci}=.50$, ri $=.66)$

0 . all subequal in size, uniformly distributed (Fig. 89)

1. most subequal, small, plus a few sparse much larger tubercles (Fig. 106)

[53] Sexual dimorphism of armature on leg IV $(\mathrm{L}=2$, $\mathrm{ci}=.50$, ri $=.83)$

0 . present (Figs 180, 181)

1. absent

[54] Prolatero-distal armature on female femur IV $(L=4, \mathrm{ci}=.25$, ri $=.57)$

0 . absent

1. present (Fig. 181)

\section{Sexual character on male leg IV}

[55] Base of external apophysis of coxa IV $(\mathrm{L}=5, \mathrm{ci}=.20$, ri $=.20)$

0. straight (Fig. 71)

1. curved frontwards (Fig. 33)

[56] Dorso-basal apophysis of femur IV $(\mathrm{L}=3, \mathrm{ci}=.33$, ri =.0)

0 . absent

1. present 
[57] Shape of the dorso-basal apophysis of femur IV $(\mathrm{L}=8, \mathrm{ci}=.37$, ri $=.50)$

0 . low, without branches (Fig. 14)

1. low, internal branch larger than external (Fig. 29)

2. high, internal branch upwards and larger than external (Fig. 44)

3. high, branches similar sized (Fig. 34)

[58] Shape of femur IV $(L=3, \mathrm{ci}=.33, \mathrm{ri}=.75)$

0 . curved inwards (Fig. 59)

1. straight to curved outwards (Fig. 45)

[59] Distribution of retrolateral spines of femur IV (consensus: $L=12, \mathrm{ci}=.33 \mathrm{ri}=.33$; most parsimonious: $\mathrm{L}=11, \mathrm{ci}=.36 \mathrm{ri}=.41$ )

0 . on entire extension

1. increasing in size apicadly (Fig. 64)

2. 1-2 larger in the median third (Fig. 60)

3. approximately 3 larger in the median third (Fig. 84)

4. absent

[60] Unarmed space between larger median retrolateral spine and anterior spine of femur IV $(\mathrm{L}=5, \mathrm{ci}=.20, \mathrm{ri}=.20)$

0 . absent (Fig. 54)

1. present (Figs $48,52,66$ )

[61] High tubercles at median-ventral region of femur IV $(L=2, \mathrm{ci}=.50, \mathrm{ri}=0)$

0 . absent (Fig. 77)

1. present (Fig. 60)

\section{Penis}

[62] Shape of ventral plate $(L=5, \mathrm{ci}=.40, \mathrm{ri}=.70)$

0. narrower at apex (YAMAgutI \& PINTO-DA-Rocha 2009, Fig. 90)

1. rectangular (Fig. 138)

2. quadrate (Fig. 170)

[63] Shape of apex $(\mathrm{L}=7, \mathrm{ci}=.42, \mathrm{ri}=.77)$

0 . straight

1. concave, U-shaped shallow and wide (Fig. 146)

2. concave, U-shaped deep and wide (Fig. 138)

3. concave, U-shaped deep and narrow (Fig. 159)

[64] Lateral lobes of ventral plate (ordered; $\mathrm{L}=7$, ci $=.28$, ri $=.50$ )

0 . absent (Fig. 166)

1. short (Fig. 135)

2. large (Fig. 149)

[65] Arrangement of basal setae of ventral plate in lateral view $(L=7, \mathrm{ci}=.14, \mathrm{ri}=.60)$

0. obliquely disposed (Fig. 134)

1. horizontally disposed (Fig. 145)

[66] Micro-setae on subapex of stylus $(L=6, \mathrm{ci}=.16$, ri $=.66)$

0. absent (Fig. 139)

1. present (Fig. 132)

[67] Granulate dorsal process of glans $(L=1, c i=1, r i=1)$

0. absent (Fig. 147)

1. present (Fig. 157) 
Appendix 2. Charater data matrix used in the cladistic analysis of Hernandariinae.

\begin{tabular}{|c|c|c|c|c|c|c|c|c|c|c|c|c|c|c|c|c|c|c|c|c|c|c|c|c|c|c|c|c|c|c|c|c|c|c|}
\hline \multirow{2}{*}{ Taxa } & \multicolumn{6}{|l|}{0} & \multicolumn{7}{|c|}{1} & \multicolumn{14}{|c|}{2} & \multicolumn{7}{|c|}{3} \\
\hline & 1 & 2 & 3 & 4 & 5 & 6 & 7 & 8 & 9 & 0 & 1 & 2 & 3 & 4 & 5 & 6 & & $7 \varepsilon$ & 8 & 9 & 0 & 12 & 2 & 3 & 4 & 5 & 6 & 7 & 8 & 9 & 0 & 1 & 2 & 3 \\
\hline B. trochanteralis & 0 & 2 & 0 & 0 & 0 & 0 & 0 & 0 & 0 & - & 0 & 0 & - & - & & -0 & & 0 & 0 & 0 & 0 & 0 & 0 & 0 & 0 & 0 & 0 & 0 & 0 & 0 & - & 0 & 0 & 1 \\
\hline O. loretoensis & 1 & 2 & 0 & 0 & 0 & 0 & 0 & 0 & 0 & - & 0 & 0 & 0 & 0 & 2 & 1 & & 20 & 0 & 1 & 0 & 0 & 0 & 0 & 0 & 0 & 0 & & 0 & 0 & - & 0 & 0 & 1 \\
\hline A. fulvigranulatus & 0 & 0 & 0 & 0 & 0 & 0 & 0 & 0 & 1 & 0 & 1 & 0 & 0 & 1 & 1 & 11 & & 0 & 0 & 0 & 0 & 0 & 0 & 0 & 0 & 0 & 0 & 0 & & 0 & - & 0 & 0 & 1 \\
\hline G. fragilis & 0 & 0 & 0 & 0 & 0 & 1 & 0 & 0 & 1 & 0 & 0 & 0 & 0 & 1 & 1 & 11 & & 0 & 0 & 0 & 0 & 1 & 1 & 0 & 1 & 0 & 0 & T & 1 & 0 & - & 0 & 0 & 0 \\
\hline G. marumbiensis & 0 & 0 & 0 & 0 & 0 & 0 & 0 & 0 & 1 & 0 & 1 & 0 & 0 & 0 & 2 & 0 & & 0 & 0 & 0 & 1 & 0 & 0 & 0 & - & - & 0 & 0 & 0 & 0 & - & 0 & 0 & 0 \\
\hline Z. leprevosti & 1 & 0 & 1 & 0 & 0 & 1 & 0 & 0 & 1 & 0 & 0 & 0 & 0 & 0 & 0 & 0 & & 0 & 0 & 0 & 0 & 0 & 0 & 0 & 0 & 0 & 0 & 0 & 0 & 0 & - & 0 & 0 & 0 \\
\hline C. elegans & 0 & 0 & 0 & 0 & 0 & 0 & 0 & 0 & 1 & 0 & 1 & 0 & 0 & 1 & 0 & 0 & 0 & 0 & 0 & 0 & 0 & 0 & 0 & 0 & 0 & 0 & 0 & 0 & 1 & 0 & - & 0 & 0 & 0 \\
\hline P. striatus & 1 & 0 & 0 & 0 & 0 & 1 & 0 & 0 & 1 & 0 & 1 & 0 & 0 & 1 & 0 & 0 & 00 & 0 & 0 & 0 & 0 & 0 & 0 & 0 & 0 & 0 & 0 & 0 & 0 & 0 & - & 0 & 0 & 0 \\
\hline M. squalidus & 1 & 0 & 1 & 0 & 0 & 0 & 0 & $0 / 1$ & 1 & 0 & 2 & 0 & 0 & 2 & 1 & 11 & 1 & 0 & 0 & 0 & 1 & 1 & 0 & 0 & 0 & 0 & 0 & 1 & 1 & 0 & 0 & 0 & 0 & 0 \\
\hline M. insulanus & 1 & 0 & 1 & 0 & 0 & 0 & 0 & $0 / 1$ & 1 & 0 & 2 & 0 & 0 & 2 & 1 & 11 & 10 & 0 & 0 & 0 & 1 & 1 & 0 & 0 & 0 & 0 & 0 & I & 1 & 0 & 0 & 0 & 0 & 0 \\
\hline A. cheguevarai sp.n. & 0 & 1 & 1 & 0 & 0 & 0 & 1 & 1 & 2 & 1 & 2 & 0 & 1 & 1 & 1 & 11 & 10 & 0 & 0 & 0 & 0 & 0 & 0 & 0 & 1 & 0 & 0 & & 2 & 0 & . & 0 & 0 & 1 \\
\hline A. spinifrons & 1 & 0 & 1 & 0 & 0 & 0 & 1 & 1 & 2 & 1 & 2 & 0 & 1 & 1 & 1 & 11 & 10 & 0 & 0 & 1 & $1 / 2$ & 0 & 0 & 0 & 1 & 0 & 0 & & 2 & 0 & O & 0 & 0 & 1 \\
\hline A. pectinifemur & 1 & 0 & 1 & 0 & 0 & 0 & 1 & 1 & 2 & 1 & 2 & 0 & 1 & 1 & 1 & 11 & 1 & 0 & 0 & 1 & 1 & 0 & 0 & 0 & 1 & 0 & 0 & 1 & 2 & 0 & 0 & 0 & 0 & 1 \\
\hline A. $r h i$ & 0 & 0 & 0 & 0 & 0 & 0 & 1 & 1 & 2 & 1 & 2 & 0 & 2 & 1 & 1 & 10 & & 0 & 0 & 1 & 2 & 0 & 0 & 0 & 1 & 0 & 0 & 1 & 2 & 0 & 0 & 0 & 0 & 1 \\
\hline A. exochus & 1 & 2 & 0 & 0 & 0 & 0 & 1 & 1 & 2 & 1 & 2 & 0 & 1 & 1 & 1 & 10 & & 0 & 0 & 1 & 2 & 0 & 0 & 0 & 1 & 0 & 0 & 1 & 2 & 0 & 0 & 0 & 0 & 1 \\
\hline A. granulatus & 1 & 1 & 0 & 0 & 0 & 0 & 1 & 1 & 2 & 1 & 2 & 0 & 1 & 1 & 1 & 10 & 00 & 0 & 0 & 1 & 2 & 0 & 0 & 0 & 1 & 0 & 0 & 1 & 2 & 0 & 0 & 0 & 0 & 0 \\
\hline H. armatifrons & 1 & 1 & 1 & 0 & 0 & 1 & 1 & 1 & 2 & 1 & 2 & 0 & 0 & 1 & 0 & 1 & 1 & 2 & 0 & 1 & 0 & 0 & 0 & 0 & 1 & 0 & 0 & 0 & 2 & 0 & 0 & 0 & 0 & 1 \\
\hline H. scabricula & 1 & 1 & 1 & 0 & 0 & 1 & 1 & 1 & 2 & 1 & 2 & 0 & 0 & 1 & 1 & 11 & 1 & 2 & 0 & 1 & 0 & 0 & 0 & 0 & 0 & 0 & 0 & 0 & 2 & 0 & O & 0 & 0 & 1 \\
\hline H. una & 0 & 1 & 1 & 0 & 0 & 1 & 1 & 1 & 2 & 1 & 2 & 0 & 0 & 1 & 1 & 11 & 1 & 1 & 0 & 0 & 0 & 0 & 0 & 0 & 1 & 1 & 0 & 0 & 2 & 0 & 0 & 0 & 0 & 1 \\
\hline H. anitagaribaldiae s & 0 & 1 & 1 & 0 & 0 & 1 & 1 & 1 & 2 & 1 & 2 & 0 & 0 & 0 & 0 & 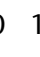 & 1 & 1 & 0 & 0 & 0 & 0 & 0 & 0 & 1 & 1 & 0 & 0 & 2 & 0 & 0 & 0 & 0 & 1 \\
\hline H. zumbii sp.nov. & 0 & 1 & 1 & 0 & 0 & 1 & 1 & 1 & 2 & 1 & 2 & 0 & 0 & 0 & 1 & ? & $?$ & 1 & 0 & $?$ & 0 & 0 & 0 & 0 & 1 & 1 & 0 & 0 & 2 & 0 & 0 & 0 & 0 & $?$ \\
\hline H. chicol & 0 & 1 & 1 & 0 & 0 & 1 & 1 & $?$ & 2 & 1 & 2 & 0 & 0 & 1 & 1 & 1 ? & $?$ & 1 & 0 & $?$ & 0 & 0 & 0 & 0 & 0 & 1 & 0 & 0 & 2 & 0 & 0 & 0 & 0 & 2 \\
\hline H. heloisae & 1 & 1 & 1 & 0 & 0 & 1 & 1 & 1 & 2 & 1 & 2 & 0 & 0 & 1 & 0 & 0 & 0 & 2 & 0 & 1 & 0 & 0 & 0 & 0 & 0 & 1 & 0 & 0 & 1 & 0 & O & 0 & 0 & 1 \\
\hline H. setulosa & 1 & 1 & 1 & 0 & 0 & 1 & 1 & 1 & 2 & 1 & 2 & 0 & 0 & 0 & 0 & 0 & 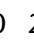 & 2 & 0 & 0 & 0 & 0 & 0 & 0 & 0 & 1 & 0 & 0 & 2 & 0 & 0 & 0 & 0 & 0 \\
\hline H. sundermannorum sp.nov. & 0 & 1 & 1 & 0 & 0 & 1 & 1 & 1 & 2 & 1 & 2 & 0 & 0 & 1 & 0 & ? & ? & 2 & 0 & $?$ & 0 & 0 & 0 & 0 & 0 & 1 & 0 & 0 & 2 & 0 & 0 & 0 & 0 & ? \\
\hline M. terrenus & 2 & 0 & 1 & 1 & 0 & 0 & 1 & 1 & 2 & $0 / 1$ & 2 & 1 & 0 & 1 & 1 & 10 & 0 & 0 & 0 & 0 & 1 & 1 & 0 & 0 & 0 & 1 & 0 & 0 & 2 & 1 & 1 & 1 & 0 & 0 \\
\hline M. dimorphicus & 2 & 0 & 1 & 1 & 0 & 0 & 1 & 1 & 2 & 0 & 2 & 1 & 0 & 1 & 1 & 10 & 0 & 0 & 0 & 0 & 1 & 1 & 0 & 0 & 0 & 1 & 0 & 0 & 2 & 1 & 1 & 1 & 0 & 0 \\
\hline Pias. brieni & 0 & 0 & 0 & 0 & 1 & 0 & 2 & 0 & 2 & 2 & 2 & 0 & 0 & 1 & 0 & 0 & 0 & 0 & 0 & 0 & 0 & 1 & 1 & 1 & 0 & 0 & 0 & 0 & 2 & 0 & - & 1 & 0 & 0 \\
\hline P. trotskyi sp.nov. & 0 & 0 & 0 & 0 & 1 & 0 & 2 & 1 & 2 & 1 & 2 & 0 & 0 & 1 & 1 & 10 & 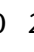 & 2 & 1 & 0 & 0 & 1 & 1 & 1 & 0 & 0 & 0 & ) & 2 & 1 & 1 & 0 & 1 & 0 \\
\hline P. funebris & 2 & 1 & 1 & 1 & 1 & 0 & 2 & 1 & 2 & 1 & 2 & 1 & 0 & 0 & 1 & 10 & 0 & 0 & 1 & 0 & 1 & 1 & 1 & 1 & 0 & 1 & 0 & ) & 2 & 1 & 1 & 1 & 1 & 0 \\
\hline P. pagu sp.nov. & 2 & 0 & 1 & 1 & 1 & 0 & 2 & 1 & 2 & 1 & 2 & 1 & 0 & 0 & 1 & 10 & 0 & 0 & 1 & 0 & 0 & 1 & 0 & 0 & 0 & 1 & 0 & 0 & 1 & 0 & 1 & & 0 & 0 \\
\hline P. telluris & 2 & 1 & 1 & 1 & 1 & 0 & 2 & 1 & 1 & $1 / 2$ & 2 & 2 & 0 & 1 & 1 & 10 & 0 & 0 & 1 & 0 & 0 & 0 & 0 & 0 & 0 & 1 & 1 & 0 & 1 & 1 & 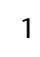 & 2 & & 0 \\
\hline P. mirim & 2 & 1 & 1 & 1 & 1 & 0 & 2 & 1 & 1 & $1 / 2$ & 2 & 2 & 0 & 1 & 1 & 10 & 0 & 0 & 1 & 0 & 0 & 1 & 1 & 0 & 0 & 1 & 1 & D & 1 & 1 & 1 & 2 & 1 & ) \\
\hline
\end{tabular}


Appendix 2. Continued.

\begin{tabular}{|c|c|c|c|c|c|c|c|c|c|c|c|c|c|c|c|c|c|c|c|c|c|c|c|c|c|c|c|c|c|c|c|c|c|c|}
\hline \multirow{2}{*}{$a x$} & \multicolumn{6}{|l|}{3} & \multicolumn{10}{|l|}{4} & \multicolumn{10}{|l|}{5} & \multicolumn{8}{|l|}{6} \\
\hline & 4 & 5 & 6 & 7 & 8 & 9 & 0 & 1 & 2 & 3 & 4 & 5 & 6 & 7 & 8 & 9 & 0 & 1 & 2 & 3 & 4 & 5 & 6 & 7 & 8 & 9 & 0 & 1 & 2 & 3 & 4 & & & 7 \\
\hline B. trochanteralis & 1 & 1 & 0 & 0 & 0 & 0 & 0 & 0 & 0 & 0 & 0 & 0 & 0 & 0 & 1 & 1 & 0 & 0 & 0 & 0 & 0 & 0 & 0 & - & 1 & 4 & - & 0 & 0 & 0 & 0 & 0 & 0 & 0 \\
\hline O. loretoensis & 1 & 1 & 0 & 0 & 0 & 0 & 0 & 0 & 0 & 0 & 0 & 0 & 0 & 0 & 1 & 3 & 0 & 0 & 0 & 0 & 1 & 1 & 1 & 0 & 1 & 0 & 0 & 0 & 1 & 0 & 2 & 0 & 0 & 0 \\
\hline A. fulvigranulatus & 1 & 1 & 1 & 1 & 1 & 0 & 0 & 0 & 0 & 0 & 0 & 0 & 0 & 1 & 1 & 2 & 0 & 0 & 0 & 0 & 0 & 1 & 1 & 1 & 0 & 3 & 0 & 0 & 0 & 1 & 1 & & 0 & 0 \\
\hline G. fragilis & 0 & 0 & 1 & 1 & 1 & 1 & 0 & 0 & 0 & 0 & 0 & 0 & 0 & 1 & 1 & 2 & 0 & 0 & 0 & 0 & 0 & 0 & 1 & 0 & 0 & 2 & 1 & 0 & 1 & 2 & 1 & 0 & 1 & 0 \\
\hline G. marumbiensis & 0 & 0 & 1 & 1 & 1 & 1 & 0 & 0 & 0 & 1 & 0 & 0 & 0 & 1 & 1 & 1 & 1 & 0 & 0 & 0 & 0 & 0 & 0 & - & ( & 4 & - & 0 & 2 & 2 & 1 & 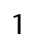 & 1 & 0 \\
\hline Z. leprevosti & 0 & 0 & 1 & 1 & 1 & 1 & 0 & 0 & 1 & 1 & 1 & 1 & 0 & 1 & 1 & 2 & 0 & 0 & 0 & 0 & 0 & 0 & 1 & - & 0 & 2 & 0 & 0 & 1 & 2 & 1 & 0 & 1 & 0 \\
\hline C. elegans & 0 & 0 & 1 & 1 & 1 & 1 & 0 & 0 & 1 & 1 & 1 & 1 & 0 & 0 & 0 & 0 & 0 & 0 & 0 & 0 & 0 & 1 & 0 & - & 0 & 0 & 0 & 0 & 2 & 1 & 1 & 0 & . & 0 \\
\hline P. striatus & 0 & 0 & 1 & 1 & 1 & 1 & 0 & 0 & 1 & 1 & 1 & 1 & 0 & 1 & 0 & 0 & 1 & 0 & 0 & 0 & 0 & $\mid$ & 1 & 0 & & 0 & 0 & 0 & 1 & 2 & 1 & 1 & 1 & 0 \\
\hline M. squalidus & 1 & 1 & 1 & 1 & 0 & 0 & 0 & 0 & 0 & 0 & 0 & 0 & 0 & 1 & 1 & 2 & 0 & 0 & 0 & 0 & 0 & 0 & 1 & 0 & 0 & 1 & 0 & 0 & 1 & 1 & 1 & & 0 & 0 \\
\hline M. insulanus & 1 & 1 & 0 & 0 & 0 & 0 & 0 & 0 & 0 & 0 & 0 & 0 & 0 & 1 & 1 & 2 & 0 & 0 & 0 & 0 & 0 & 0 & 1 & 0 & 0 & 2 & 1 & 0 & 1 & 1 & 1 & 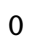 & 0 & 0 \\
\hline A. cheguevarai sp.n. & 1 & 1 & 2 & 1 & 1 & 0 & 0 & 0 & 0 & 0 & 0 & 0 & 0 & 0 & 2 & 3 & 0 & 0 & 0 & 0 & 1 & 0 & 1 & 3 & 0 & 1 & 0 & 0 & 1 & 3 & 2 & & 0 & 0 \\
\hline A. spinifrons & 1 & 1 & 1 & 1 & 1 & 0 & 0 & 0 & 0 & 0 & 0 & 0 & 0 & 0 & 2 & $2 / 3$ & 0 & 0 & 0 & 0 & 1 & 0 & 1 & 1 & 0 & 2 & $0 / 1$ & 0 & 1 & 3 & 2 & & 0 & 1 \\
\hline A. pectinifemur & 1 & 1 & 1 & 1 & 1 & 0 & 0 & 0 & 0 & 0 & 0 & 0 & 0 & 0 & 2 & 3 & 0 & 0 & 0 & 0 & 1 & 0 & 1 & 3 & 0 & 2 & 0 & 0 & 1 & 3 & 2 & 1 & 0 & 1 \\
\hline A. rhinoceros & 1 & 1 & 0 & 0 & 0 & 0 & 0 & 0 & 1 & 1 & 1 & 0 & 0 & 0 & 2 & 2 & 0 & 0 & 0 & 0 & 0 & 0 & 1 & 1 & 0 & 3 & 0 & 0 & 1 & 3 & 1 & & 1 & 0 \\
\hline A. exochus & 1 & 1 & 0 & 0 & 0 & 0 & 0 & 0 & 1 & 1 & 1 & 0 & 0 & 0 & 2 & $2 / 3$ & 0 & 0 & 0 & 0 & 1 & 0 & 1 & 1 & 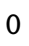 & 2 & 1 & 0 & 1 & 3 & 2 & & 1 & 0 \\
\hline A. granulatus & $0 / 1$ & 1 & 0 & 0 & 0 & 0 & 0 & 0 & 1 & 1 & 1 & 0 & 0 & 0 & 2 & 2 & 0 & 0 & 0 & 0 & 1 & 0 & 1 & 1 & 0 & 2 & 1 & 0 & 1 & 3 & 2 & 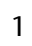 & 1 & 0 \\
\hline H. armatifrons & 1 & 1 & 2 & 1 & 1 & 0 & 0 & 0 & 0 & 0 & 0 & 0 & 1 & 0 & 2 & 3 & 0 & 1 & 0 & 0 & 1 & 0 & 1 & 0 & 0 & 1 & 0 & 0 & 1 & 2 & 1 & 1 & 1 & 0 \\
\hline H. scabricula & 1 & 1 & 2 & 2 & 1 & 0 & 0 & 0 & 0 & 0 & 0 & 0 & 0 & 0 & 2 & 3 & 0 & 1 & 0 & 0 & 1 & 0 & 1 & 1 & 0 & 2 & 0 & 0 & 1 & 2 & 1 & 1 & 1 & 0 \\
\hline H. una & 0 & 1 & 1 & 1 & 1 & 0 & 0 & 0 & 0 & 0 & 0 & 0 & 1 & 0 & 2 & 3 & 0 & 1 & 0 & 0 & 0 & 1 & 1 & 3 & 0 & 2 & 0 & 1 & 1 & 2 & 1 & 1 & 0 & 0 \\
\hline H. anitagaribaldiae sp. nov. & 0 & 1 & 1 & 1 & 0 & 0 & 0 & 0 & 0 & 0 & 0 & 0 & 1 & 0 & 2 & 3 & 0 & 1 & 0 & 0 & 0 & 0 & 1 & 2 & 1 & 1 & 0 & 0 & 1 & 2 & 2 & & 0 & 0 \\
\hline H. zumbii sp.nov. & 0 & $?$ & 1 & ? & 0 & $?$ & 0 & 0 & 0 & 0 & 0 & 0 & 1 & 1 & 2 & 3 & 0 & 0 & 0 & 0 & $?$ & 0 & 1 & 2 & 1 & 1 & 0 & 1 & 1 & 2 & 2 & 1 & 1 & 0 \\
\hline H. chicomendesi sp.nov. & 0 & $?$ & 2 & $?$ & 1 & $?$ & 0 & 0 & 0 & 0 & 0 & 0 & 1 & 0 & 2 & 3 & 0 & 1 & 0 & 0 & $?$ & 0 & 1 & 1 & 1 & 1 & 0 & 0 & 1 & 1 & 0 & 0 & 0 & 0 \\
\hline H. heloisae & 0 & 1 & 1 & 1 & 0 & 0 & 0 & 0 & 0 & 0 & 1 & 0 & 1 & 0 & 2 & 3 & 0 & 1 & 0 & 0 & 0 & 1 & 1 & 1 & 1 & 3 & 0 & 0 & 1 & 2 & 0 & 0 & 0 & 0 \\
\hline H. setulosa & 0 & 0 & 2 & 2 & 0 & 0 & 0 & 0 & 0 & 0 & 0 & 0 & 1 & 0 & 2 & 3 & 0 & 1 & 0 & 0 & 0 & 0 & 1 & 1 & 1 & 1 & 0 & 0 & 1 & 2 & 0 & 0 & 0 & 0 \\
\hline H. sundermannorum sp.nov. & 0 & $?$ & 1 & ? & 0 & $?$ & 0 & 0 & 0 & 0 & 0 & 0 & 1 & 0 & 2 & 3 & 0 & 1 & 0 & 0 & $?$ & 0 & 1 & 2 & 1 & 3 & 0 & 0 & 1 & 2 & 1 & 0 & 0 & 0 \\
\hline M. terrenus & 0 & 0 & 1 & 1 & 1 & 1 & 0 & 0 & 0 & 0 & 0 & 0 & 0 & 1 & 1 & 2 & 0 & 0 & 0 & 1 & 0 & & - & - & & - & - & - & 2 & 1 & 1 & 1 & 1 & 0 \\
\hline M. dimorphicus & 0 & 0 & 1 & 1 & 1 & 1 & 0 & 0 & 0 & 0 & 0 & 0 & 0 & 1 & 1 & 2 & 0 & 0 & 0 & 0 & 0 & 0 & 1 & 0 & 0 & 2 & 0 & 0 & 2 & 1 & 1 & 0 & 1 & 0 \\
\hline Pias. brieni & 1 & 1 & 1 & 1 & 0 & 0 & 1 & 1 & 0 & 0 & 0 & 0 & 0 & 1 & 2 & 2 & 0 & 0 & 0 & 1 & 0 & & - & - & & - & - & - & 2 & 3 & 1 & 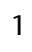 & 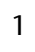 & 0 \\
\hline P. trotskyi sp.nov. & 0 & 0 & 1 & 1 & 1 & 1 & 0 & 0 & 0 & 0 & 0 & 0 & 1 & 0 & 3 & 4 & 0 & 0 & 1 & 1 & 0 & & - & - & . & - & - & - & 2 & 1 & 1 & 0 & 1 & 0 \\
\hline P. funebris & 1 & 1 & 0 & 0 & 0 & 0 & 1 & 1 & & 0 & 0 & 0 & 1 & 1 & 2 & 2 & 0 & 0 & 1 & 1 & 0 & & - & - & & & - & - & 2 & 1 & & & 0 & 0 \\
\hline P. pagu sp.nov. & 1 & 1 & 0 & 0 & 0 & 0 & 0 & 0 & 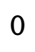 & 0 & 0 & 0 & 1 & 0 & 2 & 3 & 0 & 0 & 1 & 1 & 0 & & - & - & & & - & - & 2 & 1 & 1 & 0 & 0 & 0 \\
\hline P. telluris & 1 & 1 & 0 & 0 & 1 & 1 & 1 & 0 & 0 & 0 & 0 & 0 & 1 & 0 & 2 & 3 & 0 & 0 & 0 & 1 & 0 & & - & - & & & - & - & 2 & 1 & 1 & 0 & 1 & 0 \\
\hline P. mirim & 1 & 1 & 0 & 0 & 1 & 1 & 1 & 0 & 0 & 0 & 0 & 0 & 1 & 0 & 2 & 3 & 0 & 0 & 1 & 1 & 0 & & - & - & & & - & - & 2 & 1 & 1 & D & 1 & 0 \\
\hline
\end{tabular}

